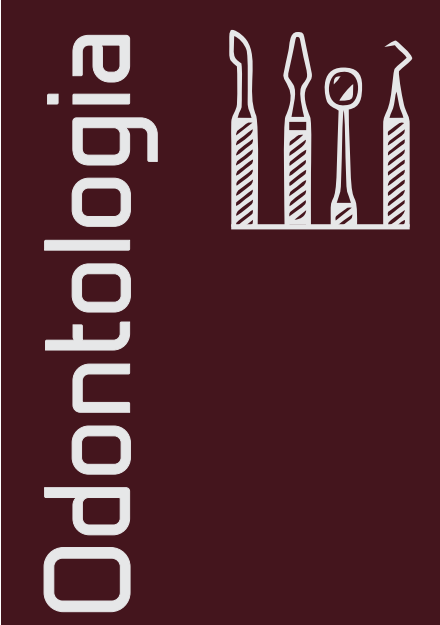

\title{
PROTOCOLOS CLÍNICOS EM DENTÍSTICA RESTAURADORA: UMA VISÃO SIMPLIFICADA
}

\section{Autores:}

Talita Arrais Daniel Mendes

Karlos Eduardo Rodrigues Lima

Eduardo da Cunha Queiroz 


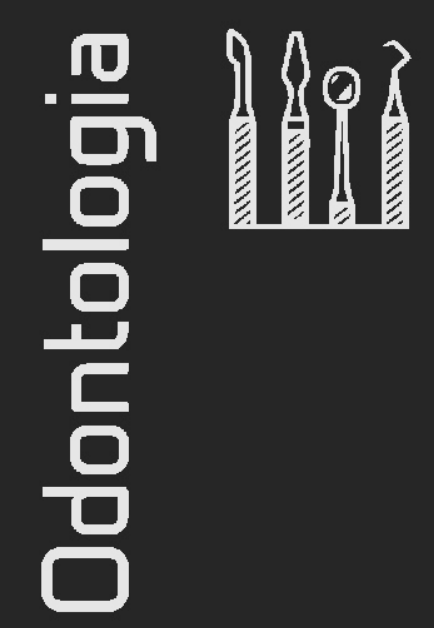

\section{PROTOCOLOS CLÍNICOS EM DENTÍSTICA RESTAURADORA: UMA VISÃO SIMPLIFICADA}

\section{Autores:}

Talita Arrais Daniel Mendes

Karlos Eduardo Rodrigues Lima

Eduardo da Cunha Queiroz

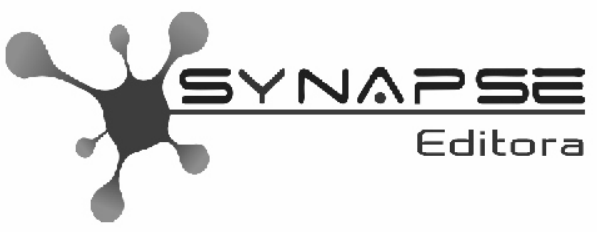

Compartilhando conhecimento 
Editor Chefe

Msc Washington Moreira Cavalcanti

Autores

Msc Talita Arrais Daniel Mendes

Karlos Eduardo Rodrigues Lima Eduardo da Cunha Queiroz

Conselho Editorial Msc Lais Brito Cangussu Msc Rômulo Maziero Msc Jorge dos Santos Mariano Dr Jean Canestri

Projeto Gráfico e Diagramação Departamento de arte Synapse Editora

Edição de Arte Maria Aparecida Fernandes

Revisão Os Autores
2021 by Synapse Editora Copyright (c) Synapse Editora

Copyright do Texto (c) 2021 Os autores

Copyright da Edição (c) 2021 Synapse Editora

Direitos para esta edição cedidos à

Synapse Editora pelos autores.

O conteúdo dos artigos e seus dados em sua forma, correção e confiabilidade são de responsabilidade exclusiva dos autores, inclusive não representam necessariamente a posição oficial da Synapse Editora.

Permitido o download da obra e o compartilhamento desde que sejam atribuídos créditos aos autores, mas sem a possibilidade de alterá-la de nenhuma forma ou utilizá-la para fins comerciais.

A Synapse Editora não se responsabiliza por eventuais mudanças ocorridas nos endereços convencionais ou eletrônicos citados nesta obra.

Todos os manuscritos foram previamente submetidos à avaliação por parte dos membros do Conselho Editorial desta Editora e pareceristas convidados, tendo sido aprovados para a publicação.

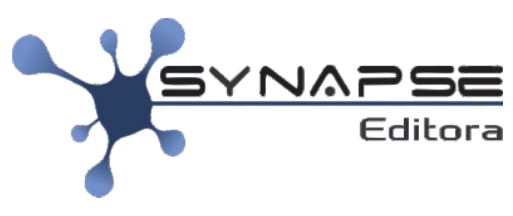

Compartilhando conhecimento

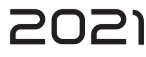




\section{M538p Mendes, Talita Arrais Daniel}

Protocolos clínicos em Dentística Restauradora: Uma visão simplificada Autores: Talita Arrais Daniel Mendes; Karlos Eduardo Rodrigues Lima; Eduardo da Cunha Queiroz. Belo Horizonte, MG: Synapse Editora, 2021, 95 p.

Formato: PDF

Modo de acesso: World Wide Web.

Inclui bibliografia

ISBN: 978-65-88890-07-3

DOI: doi.org/10.36599/editpa-2021_pcdr

1. Odontologia, 2. Dentística restauradora, 3.Saúde e Sociedade,

4. Protocolo, 6. Tratamento dentário.

I. Protocolos clínicos em Dentística Restauradora: Uma visão simplificada

CDD: $610-617.6$

CDU: $61-616.31$

SYNAPSE EDITORA

Belo Horizonte - Minas Gerais

CNPJ: 20.874.438/0001-06

Tel: + 5531 98264-1586

www.editorasynapse.org

editorasynapse@gmail.com

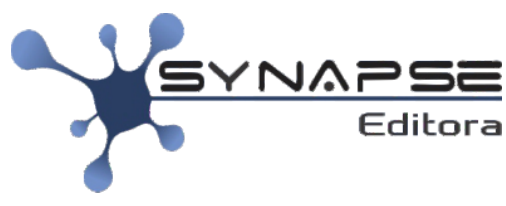

Compartilhando conhecimento

2021 


\section{Apresentação}

A Odontologia, cada vez mais, evolui afim de devolver saúde oral juntamente com bem-estar, estética e conforto ao paciente. A Dentística Operatória é uma especialidade que consegue unir todas essas características, e conta com a boa destreza e habilidade manual do operador, bem como o auxílio de biomateriais.

A visão integrada da saúde oral do paciente deve ser levada em consideração desde o momento que o mesmo chega ao âmbito clínico, para atendimento. Assim, devemos planejar tratamentos que sejam eficazes e individualizados de acordo com a expectativa e necessidade do paciente.

Neste livro iremos abordar diversos tipos de tratamentos dentro da odontologia restauradora e preventiva, podemos contar com todos os protocolos clínicos que podem ser executados nessa área odontológica, desde o preparo e adequação da saúde oral do paciente até reestabelecimento estético do sorriso por meio de técnicas mais avançadas.

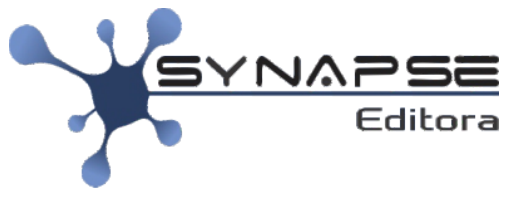

Compartilhando conhecimento ट020 


\section{Sumário}

CAPÍTULO 01:

PLANO DE TRATAMENTO

CAPÍTULO 02:

CIMENTO IONÔMERO DE VIDRO

CAPÍTULO 03:

ADEQUAÇÃO DO MEIO BUCAL

CAPÍTULO 04:

CÁRIE DENTAL

CAPÍTULO 05:

PROTEÇÃO DO COMPLEXO DENTINO-PULPAR

CAPÍTULO 06:

TÉCNICAS DE PROTEÇÃO DO COMPLEXO DENTINOPULPAR

CAPÍTULO 07:

CLAREAMENTO DENTAL

CAPÍTULO 08:

HIPERSENSIBILIDADE DENTINÁRIA

CAPÍTULO 09:

RESTAURAÇÕES COM RESINA COMPOSTA EM DENTES ANTERIORES

CAPÍTULO 10:

RESTAURAÇÕES COM RESINA COMPOSTA EM DENTES POSTERIORES 


\section{Capitulo1}

\section{PLANO DE TRATAMENTO}

Odontologia está evoluindo cada vez mais para dar o conforto e segurança aos pacientes com a realização de atendimentos humanizados, analisando o paciente no seu perfil biopsicossocial, levando em consideração fatores biológicos (genéticos, bioquímicos), psicológicos (estado de humor, personalidade), sociais (culturais, familiares, socioeconômicos) e estudando a causa e progresso da queixa principal com o objetivo de obter sucesso no tratamento ${ }^{1}$.

Durante o processo de diagnóstico, o fator mais importante a ser considerado é o plano de tratamento do paciente. Um mesmo caso clínico pode apresentar diversas condutas, e estas podem variar de acordo com o profissional, a necessidade e anseios do paciente, material a ser utilizado, idade, condições sistêmicas, e vários outros fatores. Entretanto existem alguns parâmetros para serem seguidos que serão descritos mais adiante ${ }^{5}$.

Para que se possa alcançar um diagnóstico preciso, é importante que seja realizado um bom exame clínico, através de uma anamnese detalhada e exame físico regional intra-bucal e extra-bucal minucioso com o objetivo de avaliar a história evolutiva da doença, e colher todos os dados do paciente, como: identificação, queixa principal, história da doença atual, história médica, história odontológica, antecedentes familiares, hábitos nocivos e de higiene ${ }^{3}$.

É fundamental que exista um diálogo efetivo entre o cirurgião-dentista e paciente, com a finalidade de explicar o plano de tratamento, seu desenvolvimento, execução, expectativas esperadas, e possíveis riscos inerentes aos procedimentos, bem como o tempo de duração. $O$ sucesso do tratamento está diretamente ligado a essas condutas iniciais. Uma vez que o profissional não aplique essa conduta, serão remotas as chances de selecionar um tratamento adequado ${ }^{6}$. 
Independentemente da complexidade, é importante que os procedimentos sigam uma sequência lógica e eficiente de acordo com a necessidade do paciente, otimizando as etapas, o tempo de trabalho, e permitindo maior controle na manutenção da saúde bucal para que se possa ter um bom prognóstico. Sendo assim, o plano de tratamento é dividido em 03 etapas ${ }^{2}$ :

- Fase I: eliminação e controle de doenças bucais e preservação da relação dos dentes e da saúde dos tecidos orais

- Fase II: restauração ou substituição estética e funcional

- Fase III: manutenção e controle do tratamento realizado

FASES DO PLANO DE TRATAMENTO ODONTOLÓGICO

FASE I (FASE DE PREPARO BUCAL)

\begin{tabular}{|c|c|}
\hline OBJETIVOS GERAIS & OBJETIVOS ESPECÍFICOS \\
\hline 1. Urgência & $\begin{array}{l}\text { Controle da dor e infecções agudas } \\
\text { Tratamento de traumatismos } \\
\text { Estética }\end{array}$ \\
\hline 2. Adequação do meio bucal & $\begin{array}{l}\text { Controle da placa bacteriana e orientação de dieta } \\
\text { Remoção de fator retentivo de placa } \\
\text { Escavação em massa } \\
\text { Uso de fluoretos / agentes químicos } \\
\text { Selamento de fóssulas e fissuras }\end{array}$ \\
\hline 3. Avaliação do nível de saúde & Observação dos resultados obtidos \\
\hline 4. Planejamento periodontal & Raspagem, alisamento, polimento coronorradicular e cirurgias periodontais \\
\hline 5. Planejamento cirúrgico & Exodontias, cirurgias de rebordo e frenectomias \\
\hline 6. Planejamento endodôntico & $\begin{array}{l}\text { Pulpectomia ou penetração desinfectante } \\
\text { Cirurgias paraendodônticas }\end{array}$ \\
\hline 7. Planejamento oclusal & Restabelecimentos das relações maxilomandibulares \\
\hline 8. Avaliação do nível de saúde & Observação dos resultados obtidos \\
\hline
\end{tabular}

\section{FASE II (FASE RESTAURADORA)}

\begin{tabular}{ll|l}
\hline $\begin{array}{l}\text { 1. Planejamento da reabilitação dos } \\
\text { elementos dentários }\end{array}$ & Restauração definitiva e próteses unitárias \\
\hline 2. Planejamento ortodôntico & Pequenas movimentações dentárias \\
\hline 3. Planejamento da reabilitação de oclusão & Próteses removíveis, fixas ou totais \\
\hline 4. Avaliação do nível de saúde & FASE III (FASE DE MANUTENÇÃo DA SAÚDE BUCAL) \\
\hline \multicolumn{2}{|c|}{ Manutenção } & $\begin{array}{l}\text { Consultas periódicas } \\
\text { Exame clínico / Exames complementares } \\
\text { Controle de higiene } \\
\text { Profilaxia }\end{array}$ \\
\hline
\end{tabular}

Quadro 01: quadro resumido das fases do plano de tratamento

Fonte: Adaptado de Maltz e colaboradores ${ }^{2}$. 


\section{ATENDIMENTO DE URGÊNCIA}

Pacientes que possuem traumatismos dento-faciais que envolvam a estética e função ou apresente infecções agudas necessitam de uma intervenção imediata ${ }^{2}$.

\section{FASE I OU FASE DE PREPARO BUCAL}

O principal objetivo dessa etapa é eliminar e controlar as doenças bucais e buscar manutenção dos dentes e saúde dos tecidos orais ${ }^{2}$. Idealmente se inicia pelos procedimentos de urgência e adequação do meio bucal ${ }^{6}$. A qualidade das restaurações é um fator primordial para a manutenção da saúde dos tecidos periodontais, uma vez que restaurações irregulares podem causar uma inflamação no periodonto e interferir no sucesso do tratamento ${ }^{2}$. Outro fator importante que deve ser observado, é a avaliação dos sinais e sintomas relacionados ao sistema mastigatório, articulação temporomandibular, músculos e estruturas dentárias ${ }^{3}$. É de suma importância que ainda nessa fase, possa ser realizado o planejamento periodontal, cirúrgico, endodôntico, oclusal e reavaliação minuciosa do nível de saúde através dos resultados obtidos, que estão diretamente ligados à uma boa instrução de higiene oral orientada pelo Cirurgião-Dentista, e conduta do paciente em ser responsivo ao tratamento ${ }^{2}$.

\section{FASE II OU FASE RESTAURADORA}

Estão incluídos procedimentos envolvendo as especialidades de Dentística, Ortodontia e Prótese ${ }^{2}$. Em geral, são realizadas as restaurações definitivas e confecções de prótese unitárias, pequenas movimentações dentárias, e reabilitação da oclusão por meio de próteses fixas, removíveis ou totais. Lembrando sempre que deve-se individualizar o paciente frente à necessidade do seu tratamento, e ao final de cada etapa avaliar os resultados obtidos a fim de se alcançar um bom prognóstico 4 .

\section{FASE III OU FASE DE MANUTENÇÃO DA SAÚDE BUCAL}

Tem como principal objetivo a preservação de todo o trabalho que foi realizado na Fase I e Fase II. Nessa etapa é fundamental que se tenha um controle efetivo do biofilme e dieta, onde através de um diálogo com o paciente, o profissional deve motivá-lo a seguir as orientações do tratamento como a utilização de dentifrício fluoretado, bons hábitos de higiene oral, e agendamento de consultas periódicas que podem variar de três meses à um ano à depender da necessidade do paciente ${ }^{2}$. 


\section{REFERÊNCIAS}

1. GUERRA, Camila Tuanny et al. Reflexões sobre o conceito de atendimento humanizado em Odontologia. Archives of Health Investigation, v. 3, n. 6, 2015.

2. MALTZ, Marisa et al. Cariologia: Conceitos Básicos, Diagnóstico e Tratamento Não Restaurador: Série Abeno: Odontologia Essencial-Parte Clínica. Artes Medicas, 2016.

3. MILORO, Michael. Princípios de cirurgia bucomaxilofacial de Peterson. In: Princípios de cirurgia bucomaxilofacial de Peterson. 2008. p. 766-766.

4. MOREA, Camillo; DOMINGUEZ, Gladys Cristina; SOARES, Mario Sergio. Preparo pré-protético multidisciplinar de paciente adulto com ausência dentárias e doença periodontal severa. Ortodontia e ortopedia facial: casos clínicos, 2010.

5. PEGORARO, Luiz Fernando et al. Prótese Fixa: bases para o planejamento em reabilitação oral. Artes Médicas Editora, 2013.

6. POI, Wilson Roberto et al. Plano de tratamento em odontologia: análise dos planos propostos por alunos de graduação. Pesquisa Brasileira em Odontopediatria e Clínica Integrada, v. 7, n. 3, p. 297-301, 2007. 


\section{Capitulo2}

\section{CIMENTO IONÔMERO DE VIDRO}

O Cimento lonômero de Vidro (CIV) é um material ácido-base que tem como função principal restabelecer a estrutura dental perdida ${ }^{2}$. 0 pioneiro na sua formulação foi Wilson Kent em 1971, onde o mesmo combinou as propriedades de cimento de silicato e policarboxilato de zinco, um apresentando características anti-cariogênicas e outro capacidade de adesão ao substrato dentário, respectivamente. Essa associação permitiu avanços na promoção da saúde devido à suas características de liberação de flúor, além de ser um material versátil e com boa durabilidade podendo ser aplicado em diversas áreas da odontologia 4,5 . Este material pode ser classificado quanto à sua composição (convencional, anidro, reforçados por metal e modificados por resina) ou quanto à sua indicação (cimentação, restauração e selantes).

\section{COMPOSIÇÃO DO CIV CONVENCIONAL}

O CIV apresenta-se na forma de pó e líquido, sendo o pó formado por sílica e alumina (responsáveis por promover a resistência do material) e fluoreto de cálcio (responsável pela liberação de flúor e iniciação da reação de presa). De acordo com a indicação do material, as partículas do pó podem apresentar diferentes tamanhos 1,3 .

O líquido é formado em sua maior parte por ácido poliacrílico (responsável pela união química do material ao dente), ácido tartárico (tem como função diminuir a viscosidade do material e aumentar o tempo de trabalho) e ácido iatacônico (evita as ligações entre o ácido poliacrílico e aumenta a vida útil do cimento de ionômero de vidro (CIV)) ${ }^{5}$. 


\section{REAÇÃO DE PRESA}

Didaticamente a sua reação de presa pode ser dividida em três fases 4 :

1. Ionização do Ácido Poliacrílico e Deslocamento de Íons;

2. Formação da Matriz de Polissais;

3. Formação do Gel de Sílica e Presa Final

Fase 01 -lonização do ácido poliacrílico e deslocamento de íons

Nessa etapa o ácido poliacrílico vai se ionizar e reagir com o pó, liberando alguns íons: sódio, cálcio, alumínio e flúor. Neste momento, cerca de $70 \%$ a $80 \%$ das partículas não reagem completamente, e estas são responsáveis pela resistência inicial do ionômero. Clinicamente pode-se observar um aspecto brilhante, sendo o momento ideal para sua inserção na cavidade 4 .

Esse momento é considerado como crítico, uma vez que a água que ainda não reagiu completamente pode sofrer sinérese, sendo fundamental a presença de um bom isolamento absoluto/relativo. Caso o material sofra sinérese, suas propriedades mecânicas serão reduzidas, o que pode acarretar problemas como: trincas e contrações 4 .

\section{Fase 02 - Formação da matriz de polissais}

Essa fase se inicia após a inserção do material na cavidade, onde as partículas que não haviam reagido na fase 01 irão reagir com o cálcio presente no dente e entre si com o cálcio inerente ao próprio material, formando complexos de carboxilados de cálcio. Clinicamente pode-se observar uma característica de opacidade e perda de brilho do material ${ }^{4}$. Após a adaptação do material na cavidade deve-se esperar até 08 minutos para remover o isolamento, para que 0 material ganhe resistência suficiente, e nesse momento é recomendado que seja realizada a proteção do ionômero com vernizes ou sistema adesivo ${ }^{4}$.

\section{Fase 03-Formação do gel de sílica e presa final}

Essa fase termina após 48 horas da realização da restauração, nela os polissais continuam se formando e irão reagir com a sílica presente no pó para formar o gel de sílica, reação está denominada de gelificação. A partir desse período, se tem um ganho significativo nas propriedades mecânicas ${ }^{4}$.

É contraindicado realizar acabamento ou polimento do ionômero de vidro, pois isso irá interferir negativamente na formação da Matriz de Polissais durante a fase 2 e reduzir suas propriedades mecânicas. Durante o ajuste oclusal recomenda-se instrumentos manuais de cort 4 . 


\section{PROPRIEDADES DO CIMENTO IONÔMERO DE VIDRO}

Apresenta uma união química melhor em dentina. Ele tende a liberar flúor durante a vida útil da restauração e atua na mineralização de lesões de cárie. 0 CIV apresenta um coeficiente de coesão térmica linear similar ao da dentina. Não é um material muito estético, quando comparado por exemplo, com resinas compostas. A propriedade de resistência mecânica é reduzida. Sofre facilmente sorção ou solubilidade, ou seja, absorve água e se dissolve no meio presente, por isso é importante que ao final da fase 02 de reação de presa seja feita a proteção do material com vernizes ou sistema adesivo 1,4 .

\section{TIPOS DE IONÔMEROS DE VIDRO QUANTO A COMPOSIÇÃO}

lonômero de vidro anidro

Possuem composição similar aos convencionais, no entanto a sua diferença é que os ácidos presentes nos líquidos do material passaram por um processo de liofilização e foi transformado em pó 5 .

lonômero de vidro reforçados pormetal

Esse tipo de ionômero também é bastante similar aos convencionais, porém foram adicionadas partículas de prata e limalha, o que permitiu uma alta resistência ao material, em contrapartida apresentam uma estética desfavorável devido a presença do metal ${ }^{5}$.

lonômero de vidro modificados por resina

Nesse tipo de cimento foi feita a adição do monômero resinoso hidroxietilmetacrilato $(\mathrm{HEMA})^{5}$. Esse material é bastante versátil, sua capacidade de ser fotoativado permite um maior tempo de trabalho e se une quimicamente a resinas compostas e adesivo ${ }^{5}$.

\section{PROTOCOLO DE APLICAÇÃO DO IONÔMERO DE VIDRO CONVENCIONAL}

Material necessário

- Cimento de ionômero de vidro convencional;

- Pincel descartável (microbrush);

- Verniz; 
- Rolo de algodão;

- Gases;

- Ácido poliacrílico.

Instrumental necessário

- Placa de vidro;

- Espátula de metal número 24;

- Seringa centrix;

- Ponteira de seringa centrix;

- Espátula de inserção número 1;

- Espátula hollemback3s.

Passo a passo clínico

- Realizar o condicionamento ácido da cavidade dental com ácido poliacrílico por 20 segundos, seguidos de lavagem e secagem com rolos de algodão;

- Preparar o material seguindo a proporção presente nas instruções do fabricante;
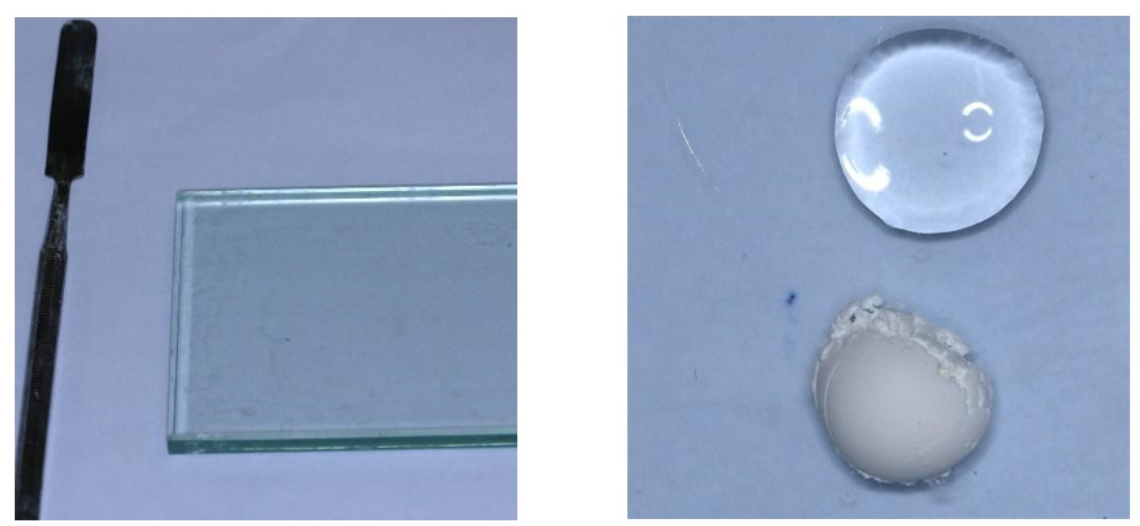

Figura 1: Preparação do material

Fonte: autores, 2021.

- Divide-se o pó em 02 porções;

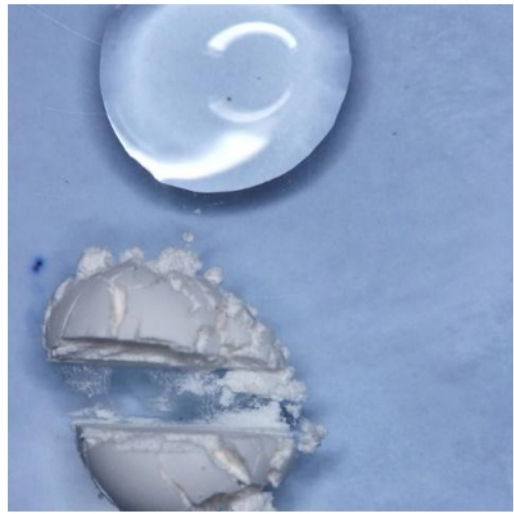

Figura 2: Divisão do pó em 02 porções Fonte: autores, 2021. 
- Com a espátula 24 realiza-se a manipulação do material por meio de movimento de aglutinação por tempo de no máximo 60 segundos;

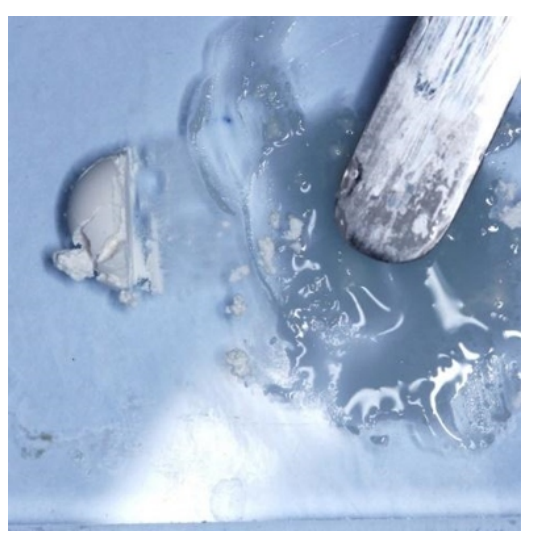

Figura 3: Manipulaçãodo material Fonte: autores, 2021.

- Checagem do aspecto brilhante da superfície;

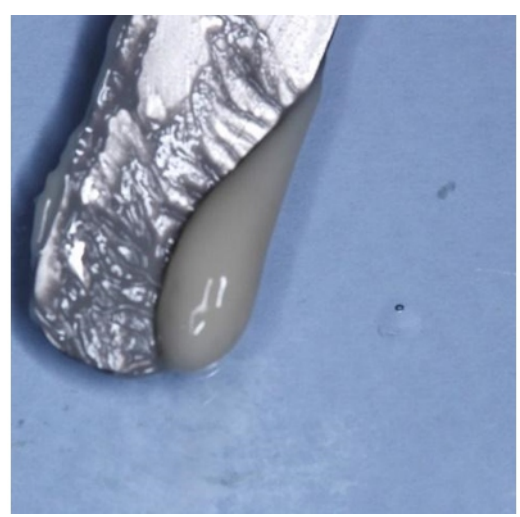

Figura 4: Preparação do material Fonte: autores, 2021.

- Com o auxílio de uma espátula de inserção, inserir o material na ponta da seringa Centrix e inserir na cavidade com o auxílio da seringa Centrix (cuidado para não haver formação de bolhas);

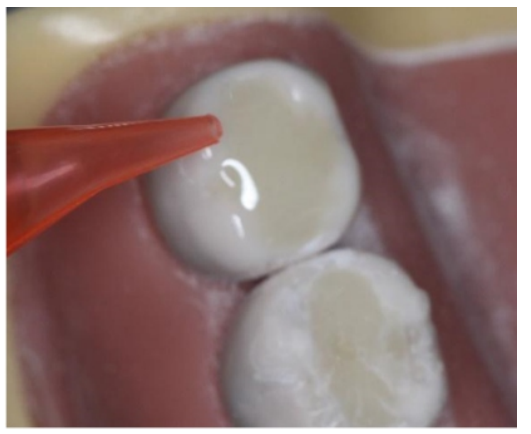

Figura 5: Aplicação do material Fonte: autores, 2021. 
- Esperar a presa inicial, após 4 minutos, para realização da remoção dos excessos com auxílio da Espátula Hollemback 3s;

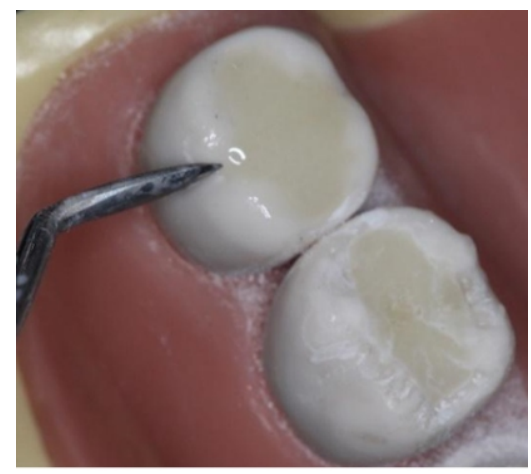

Figura 6: Presa inicial do material Fonte: autores, 2021.

- Esperar 8 minutos para aplicação do verniz;

- Aplicação do verniz, 2 camadas intercaladas com jatos de ar;

- Remoção do isolamento e ajuste oclusal (preferível a não utilização de instrumentos rotatórios). 


\section{REFERÊNCIAS}

1. ANUSAVICE, Kenneth J. Phillips materiais dentários. Elsevier Brasil, 2013.

2. DE OLIVEIRA, Talita Miranda et al. AVALIAÇÃO DA ALTERAÇÃO DIMENSIONAL DO CIMENTO DE IONÔMERO DE VIDRO CONVENCIONAL UTILIZANDO DIFERENTES TIPOS DE PROPORÇÕES PÓ/LÍQUIDO. PARTE II. Revista Ciências e Odontologia, v. 3, n. 2, p. 35-42, 2019.

3. OLIVEIRA, R. C. et al. Restaurações ART com Cimento de lonômero de Vidro encapsulado X pó-líquido: Ensaio clínico randomizado. Brazilian Oral Research, v. 33, p. 75, 2019.

4. REIS, Alessandra; LOGUERCIO, Alessandro Dourado. Materiais dentários diretos: dos fundamentos à aplicação clínica. Santos, 2007.

5. SPEZZIA, Sérgio. Cimento de ionômero de vidro: revisão de literatura. Journal of Oral Investigations, v. 6, n. 2, p. 74-88, 2017. 


\section{Capitulo3}

\section{ADEQUAÇÃO DO MEIO BUCAL}

cárie é uma doença multifatorial e biofilme dependente, na qual surge frente a um desequilíbrio do $\mathrm{pH}$ da boca levando o dente à uma desmineralização ${ }^{2}$. A adequação do meio bucal consiste em medidas para criar um ambiente favorável à paralisação da doença cárie e controle dos microrganismos cariogênicos associados a fatores retentivos de placa bacteriana, tendo como seu principal objetivo resgatar o padrão ecológico do meio bucal ${ }^{1,3}$.

\section{FATORES QUE INFLUENCIAM NA PROGRESSÃO DA CÁRIE}

É primordial conhecer sobre os diversos fatores que influenciam na progressão da cárie. $O$ fator determinante para que as lesões cariosas possam surgir é o acúmulo de bactérias da microbiota oral sobre a superfície dos dentes, além de outras causas, tais como: taxa do fluxo salivar, alto consumo de carboidratos fermentáveis e elevadas concentrações de flúor, cálcio e fosfato nos fluidos orais ${ }^{2}$.

\section{MEDIDAS A SEREM TOMADAS PARA ADEQUAÇÃO DO MEIO BUCAL}

O cirurgião-dentista tem o papel de quantificar a qualidade do biofilme e observar as características da cárie subjacente à placa. Com o intuito de individualizar o paciente e restaurar a manutenção da sua saúde bucal, existe uma sequência didática com algumas medidas que podem ser tomadas, e serão descritas mais detalhadamente abaixo ${ }^{2,5}$ :

1. Controle Efetivo da Placa (Remoção do Biofilme)

2. Instrução de Higiene Oral

3. Orientação da Dieta 
4. Remoção dos Fatores Retentivos

5. Uso de Agentes Bioativos/Remineralizadores

6. Escavação em Massa

7. Reavaliação e Tratamento Restaurador e Definitivo

8. Acompanhamento

\section{CONTROLE EFETIVO DA PLACA}

Para encontrar o Índice de Placa Visível (IPV) do paciente, é realizada evidenciação da placa bacteriana com evidenciadores à base de fucsina em todas as faces dos dentes. Ao aferir o índice, considera-se satisfatório um resultado menor que $25 \%$, irregular entre $25 \%$ e $40 \%$ e insatisfatório acima de $40 \%^{2}$. O controle mecânico da placa é importante na redução dos microrganismos envolvidos no ciclo do processo carioso e no balanço dinâmico entre a saliva e o dente, sendo sua efetividade completamente ligada à motivação do paciente. Alguns fatores auxiliam no controle mecânico da placa, tais como: destreza manual e adequação dos instrumentos de limpeza, que podem ser as escovas convencionais, elétricas, interdentais, unitufo, fita dental e fio dental, cada uma com sua indicação ${ }^{2}$.

\section{INSTRUÇÃO DE HIGIENE ORAL}

O profissional tem o dever de instruir da forma correta o paciente a ter bons hábitos de higiene oral, demonstrando as técnicas de escovação de acordo com a indicação do paciente, a importância da utilização do fio dental e colutórios como métodos de prevenção da saúde bucal ${ }^{3}$.

\section{ACONSELHAMENTO DIETÉTICO}

A falta da dieta tem sido um limitante de controle e efetividade no tratamento da doença cárie. É necessário orientar a redução no consumo de açúcar, uma vez que o fator determinante não é a quantidade e sim a frequência do consumo, sendo um fator de risco para o paciente desenvolver lesões ativas ${ }^{2}$.

\section{REMOÇÃO DOS FATORES RETENTIVOS DE PLACA BACTERIANA}

É essencial a execução de um exame clínico detalhado, e radiográfico quando necessário, para avaliar possíveis excessos/falhas de restaurações, pois uma vez presente, devem ser corrigidas a fim de evitar a progressão da cárie ou surgimento de cáries secundárias, bem como a formação de cálculos de origem supra-gengivais, que também são considerados fatores retentivos de placa bacteriana e portanto devem ser removidos 2,4 . 


\section{USO DE AGENTES BIOATIVOS}

São excelentes alternativas para ajudar no restabelecimento do meio, entretanto usados isoladamente não irão ser eficazes. Dentre eles, podemos destacar o Flúor, Clorexidina, Triclosan, Xilitol e lonômero de Vidro ${ }^{4}$.

O flúor é altamente reativo com os tecidos mineralizados, apresenta excelentes propriedades remineralizadoras e preventivas 4 .

A clorexidina é agente antimicrobiano que possui um amplo espectro de ação, sendo as bactérias gram-positivas mais sensíveis. Atua como agente antigengivite e antibiofilme apresentando um bom efeito antiplaca, entretanto requer a colaboração do paciente por possuir um gosto ruim, e causar manchas nos dentes quando administrado inadequadamente por longos períodos 4 .

O Triclosan tem ação antimicrobiana, antifúngica, bactericida e bacteriostática, efeito antiplaca e apresenta baixa substantividade. É uma substância muito solúvel em meio oral e se torna mais eficaz quando em maiores concentrações e adicionada de ácido maleico e citrato de zinco 4 .

O xilitol é um açúcar à base de cálcio e reduz a recolonização bacteriana ao longo do tempo. Não é metabolizado por bactérias cariogênicas e apresenta-se na forma de chiclete que deve ser mascado por 20 minutos, melhorando a capacidade tampão e favorecendo na remineralização 4 .

O ionômero de vidro é um excelente material durante a escavação em massa, ajudam na reconstrução da dentina, é bactericida e bacteriostático, possui boa adesão aos tecidos dentais, entretanto exibe baixas propriedades mecânicas 4 .

\section{ESCAVAÇÃO EM MASSA}

Consiste na remoção do tecido cariado das paredes circundantes seguida de restauração com ionômero de vidro (protocolo clínico descrito no fim do capítulo) ${ }^{2}$.

\section{REAVALIAÇÃO E TRATAMENTO RESTAURADOR DEFINITIVO}

Após 90 dias deve ser feita uma reavaliação do IPV e das restaurações. Caso tenha uma redução de $60 \%$ no IPV e o processo carioso esteja paralisado, devese realizar a restauração definitiva ${ }^{2}$. 


\section{ACOMPANHAMENTO}

É realizada a manutenção e proservação através de consultas periódicas ${ }^{2}$.

Material necessário para realização da adequação do meio bucal

- Cimento ionômero de vidro convencional

- Cimento ionômero de vidro modificado por resina

- Pincel descartável (microbrush)

- Verniz Papel carbono

- Rolo de algodão

- Gases

- Clorexidina 0,12\% para bochecho

- Flúor

- Seringa descartável

Instrumental necessário

- Placa de vidro

- Espátula de metal número 24

- Seringa Centrix

- Kit de Ponteira de seringa Centrix

- Espátula de inserção número 1

- Espátula Hollemback 3s

- Curetas de Gracey 5-6; 7-8; 11-12; 13-14

- Foice Morse 0-00

- Foice Mccall 11-12

- Kit clínico (bandeja, espelho oral, sonda exploradora)

- Caneta de alta rotação

- Caneta de baixa rotação

- Escova de Robinson

- Grampos para isolamento absoluto 210, 211, 212, 26, W8A, 202, 203, 204, 205, 206 e 209

- Arco de Young

- Colheres de dentinas $n=5,11 \frac{1}{2}, 17,19,20$

- Brocas de aço esféricas números 2, 3, 4, 5 e 6

- Pontas diamantadas esféricas 1011,1012, 1014

- Ponta diamantada tronco cônica 3139

- Perfurador de borracha

- Pinça portagrampos

- Tesoura

- Recortadores de margens gengival

- Seringa Carpule 
Passo a passo clínico

- Exame inicial (clínico visual e verificação do índice de placa) para avaliação se o paciente está no perfil de adequação do meio oral;

- Realizar instrução de higiene oral e remoção efetiva de placa bacteriana com auxílio da escova de Robinson;

- Remoção de fator retentivo de placa;

- Raspagem supragengival com curetas periodontais de gracey;

- Remoção de restaurações em excesso.

- Uso de agente bioativos (a depender do perfil de cada paciente: paciente com a presença de biofilme periodontopatogêncio em preponderância, fazer o uso de colutório de clorexidina, no período inicial; paciente com a presença preponderante de biofilme cariogênico: uso de aplicação tópica de flúor);

- Escavação em massa e uso de ionômero de vidro:

- Isola-se o campo operatório com auxílio do arco de Youg e Grampos para isolamento absoluto ;

o Remoção do tecido cariado dos elementos que estão acometidos por cárie em dentina, com uso de brocas esféricas para remoção de tecido cariado e colheres de dentina do tamanho compatível com a cavidade;

o manipula-se o cimento ionômero de vidro com auxílio da placa de vidro, espátula de metal número 24;

o Restaura-se com cimento ionômero de vidro com auxílio da seringa e ponteira Centrix e espátula de inserção número 01;

o Realiza-se os ajustes oclusais.

Após 90 dias, realizar reavaliação do índice de placa, se houver indicação, prosseguimento para próxima fase de tratamento. 


\section{REFERÊNCIAS}

1. ASSIS, Patricia Diletieri de et al. ADEQUAÇÃO DO MEIO BUCAL E REALIZAÇÃO DE TRATAMENTOS PRÉ-PROTÉTICOS PARA REINTEGRAR O PACIENTE ODONTOLÓGICO NA SEQUÊNCIA DE REABILITAÇÃO ORAL. Odontologia Clínico-Científica (Online), v. 14, n. 4, p. 831-834, 2015.

2. MALTZ, Marisa et al. Cariologia: Conceitos Básicos, Diagnóstico e Tratamento Não Restaurador: Série Abeno: Odontologia Essencial-Parte Clínica. Artes Medicas, 2016.

3. PRADO, Bruno Nifossi; PASSARELLI, Dulce Helena Cabelho. Uma nova visão sobre prevenção do câncer bucal no consultório odontológico. Revista de odontologia da universidade cidade de São Paulo, v. 21, n. 1, p. 79-85, 2017.

4. REIS, Alessandra; LOGUERCIO, Alessandro Dourado. Materiais dentários diretos: dos fundamentos à aplicação clínica. Santos, 2007.

5. RIBEIRO, JOICE et al. Adequação de meio bucal previamente ao tratamento restaurador definitivo. Anais do Salão de Ensino e de Extensão, p. 42, 2015. 


\section{Capitulo 4}

\section{CÁRIE DENTAL E REMOÇÃO DO TECIDO CARIADO}

Cárie é definida como uma doença multifatorial e biofilme dependente, para que ela possa se desenvolver é necessário que o paciente tenha a presença do biofilme, e exista um desequilíbrio no balanço entre o mineral do dente e o fluido do biofilme, de forma que o pH do meio fique ácido, deixando o dente susceptível a desmineralização 3,6 .

Para que o processo carioso possa se instalar vários fatores podem estar relacionados, tais como: hábitos dietéticos, e de higiene oral, hábitos comportamentais, contexto socioeconômico e fatores genéticos 2,3 .

\section{DIAGNÓSTICO}

O diagnóstico é muito importante, pois a partir dele é possível traçar um plano de tratamento adequado para o paciente, e passar as instruções de higiene oral. Além de obter dados epidemiológicos sobre a doença e fornecer dados importantes para medidas de saúde pública à nível nacional ${ }^{5}$. Em lesões clinicamente parecidas com a cárie como a fluorose dentária, o diagnóstico deve ser feito da forma mais minuciosa possível ${ }^{1,5}$.

\section{PRÉ-REQUISITOS PARA UM BOM DIAGNÓSTICO}

Para que se tenha um bom diagnóstico é importante a realização de uma anamnese detalhada, de modo a individualizar o paciente e identificar os fatores de risco (hipossalivação, dieta, hábitos de higiene) para o desenvolvimento do processo carioso. E um excelente exame clínico, onde deve-se verificar a quantidade, qualidade e nichos de retenção da placa bacteriana bem como uma boa profilaxia para melhor visualização da lesão ${ }^{5}$. 


\section{AVALIAÇÃO DA CÁRIE}

Durante o processo de avaliação da cárie, o ideal é que seja feita uma eficiente secagem com o jato de ar na área a ser visualizada, e não é recomendado o uso da sonda exploradora, uma vez que a pressão exagerada sobre lesões iniciais pode levar a defeitos irreversíveis em um esmalte potencialmente remineralizável. A única exceção são em casos de lesões secundárias e avaliação da consistência de cáries já cavitadas, sendo neste caso o uso da sonda com ponta romba 5 .

\section{CLASSIFICAÇÕES DA CÁRIE}

A cárie pode ser classificada quanto ao surgimento, atividade, localização, sítio anatômico, presença de cavidade, tecido envolvido, e quanto a presença ou não de restauração prévia na superfície do dente ${ }^{5}$.

Tabela 01: Diagnóstico de cárie nas superfícies de esmalte e dentina

\begin{tabular}{|l|l|l|l|}
\hline \multicolumn{1}{|l|}{ PARÂMETROS } & \multicolumn{2}{c}{ CLASSIFICAÇÃO } & \multicolumn{2}{c|}{ ESMALTE } \\
\hline \multirow{3}{*}{ Textura } & $\begin{array}{l}\text { Hígido } \\
\text { Lesão ativa } \\
\text { Lesão inativa }\end{array}$ & $\begin{array}{l}\text { Superfície lisa } \\
\text { Superfície rugosa } \\
\text { Superfície lisa }\end{array}$ & $\begin{array}{l}\text { Dura } \\
\text { Amolecida, úmida } \\
\text { Dura, seca }\end{array}$ \\
\hline \multirow{2}{*}{ Brilho } & $\begin{array}{l}\text { Lesão ativa } \\
\text { Lesão inativa }\end{array}$ & $\begin{array}{l}\text { Opaca } \\
\text { Brilhante }\end{array}$ & $\begin{array}{l}\text { Opaca } \\
\text { Brilhante }\end{array}$ \\
\hline \multirow{2}{*}{ Cor } & $\begin{array}{l}\text { Hígido } \\
\text { Lesão ativa } \\
\text { Lesão inativa }\end{array}$ & $\begin{array}{l}\text { Bancido } \\
\text { Marrom } \\
\text { escurecido/preto }\end{array}$ & $\begin{array}{l}\text { Amarelado } \\
\text { Alaranjado ou Marrom claro } \\
\text { Marrom/escurecido }\end{array}$ \\
\hline
\end{tabular}

Fonte: Adaptado de Maltz e colaboradores ${ }^{5}$.

Cáries ativas em esmalte também podem ser chamadas de manchas brancas ativas, e geralmente estão próximas à margem cervical e quando presentes pode causar uma inflamação gengival no periodonto, enquanto as cáries inativas em esmalte são conhecidas como manchas brancas inativas e estas estão distantes da margem cervical, encontrando-se mineralizadas e sem inflamação no periodonto.

Devido ao conteúdo orgânico da dentina, a cárie consegue progredir mais rápido. Cáries ativas em dentina geralmente apresentam atividade de lesão ativa no esmalte adjacente e cáries inativas em dentina apresentam a exposição do tecido dentinário com um aspecto seco e de coloração escurecida. 


\section{REMOÇÃO SELETIVA DO TECIDO CARIADO}

Durante um longo período de tempo, o tratamento dessas lesões cariosas se baseavam em princípios mais invasivos de extensão preventiva no qual era feito a remoção de tecido dental hígido adjacente à lesão de cárie, tendo como objetivo prevenir que as lesões de cárie surgissem naquela região novamente ${ }^{1}$.

Atualmente a odontologia restauradora busca cada vez mais pela preservação de tecidos dentários. Assim sendo, existem diversas condutas baseadas nesse contexto, tais como: mineralização de cárie retidas apenas em esmalte, selamento de cárie, bem como a remoção seletiva de cárie ${ }^{1,3}$.

A remoção seletiva do tecido cariado (RSC) caracteriza-se pela remoção da camada mais superficial da dentina acometida pela cárie, chamada infectada. Esta é caracterizada por um tecido amolecido, úmido, cujo colágeno encontra-se degradado, não expondo os cornos pulpares, com pouco ou nenhum potencial de remineralização tecidual. A cárie é removida totalmente das paredes circundantes do preparo cavitário. A camada mais profunda, também conhecida por dentina afetada, caracteriza-se por um tecido mais endurecido e seco, cuja trama de colágeno encontra-se intacta e, portanto, passível de remineralização ${ }^{6}$.

Além de preservar o desgaste desnecessário de tecidos sadios, esse tipo de abordagem também propicia maior conforto para o paciente, o que é extremamente relevante dentro da odontopediatria ${ }^{3,4}$. Apesar de ter sido inicialmente utilizada para o tratamento de lesões cariosas na odontopediatria, a Remoção Parcial/Seletiva de lesões cariosas ganhou espaço também entre os adultos, isto porque demonstrou-se bastante eficaz, por tratar-se de um método de menor invasão e que propicia a manutenção da vitalidade da polpa, evitando a necessidade de tratamento endodôntico ou outros procedimentos mais invasivos 6 .

A RSC já tem sido relatada como uma terapia promissora, que mostra sucesso a níveis microbiológicos, histológicos, bioquímicos e radiográficos, no entanto é uma técnica que exige conhecimento e habilidade do operador quanto a identificação do tipo de substrato a ser trabalhado ${ }^{2}$, no entanto outros estudos demonstram taxas de insucesso ${ }^{2}$, sendo sua utilização bastante controversa, por isso a sua utilização ainda encontra resistência por parte de profissionais.

Essa conduta é uma alternativa eficaz no tratamento de lesões profundas de cárie em dentes decíduos e permanentes, e apresentam bons resultados clínicos e radiográficos, além de manter a integridade do órgão pulpar, permite um maior conforto ao paciente, e por ser uma técnica mais conservadora evita procedimentos mais invasivos. 


\section{PROTOCOLO - REMOÇÃO TOTAL DO TECIDO CARIADO}

Material necessário:

- Lençol de borracha

- Rolo de cada de matriz metálica de $5 \mathrm{~mm}$ e $7 \mathrm{~mm}$

- Caneta para marcação do lençol

- Vaselina

- Lubrificante hidrossolúvel

- Caixa de tiras de lixa

- Rolo de fio Dental

- Gases (1 pacote)

- Rolo de algodão

Instrumental necessário

- Arco de Young Espátula de ponta romba

- Grampos: 200 ao 205 molares, 206 ao 209 pré-molares, 210 ao 212 Anterior, 212 L, $212 \mathrm{R}, 26$, W8A

- Colheres de dentinas $n=5,11 \frac{1}{2}, 17,19,20$

- Brocas de aço esféricas números 2, 3, 4, 5 e 6

- Pontas diamantadas esféricas 1011,1012, 1014

- Ponta diamantada tronco cônica 3139

- Perfurador de borracha

- Pinça porta grampos

- Tesoura

- Recortadores de margem gengival

- Seringa Carpule

- Escova de Robinson para cavidade

- Kit clínico: bandeja, sonda exploradora número 5, sonda periodontal OMS e espelho bucal

- Posicionador radiográfico Colgadura (a depender da demanda dos pacientes)

Passo a passo

- Inspeção visual do elemento com cárie, diagnóstico adequado (visual e radiográfico) seguido de anestesia intraoral;

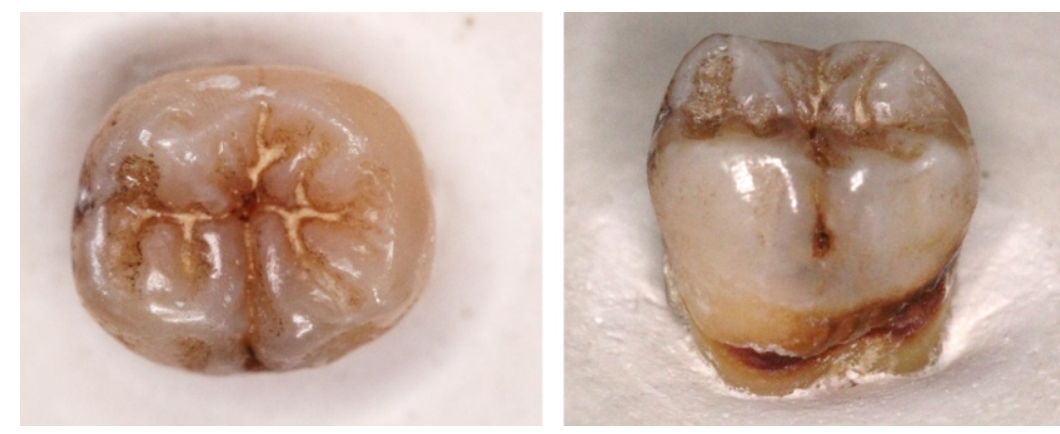

Figura 1: Inspeção visual do elemento com cárie Fonte: autores, 2021. 
- Realização do Isolamento absoluto ou relativo;

- Acesso a cavidade de cárie, se há presença de esmalte, utilizar pontas esféricas diamantadas para acesso da cavidade.
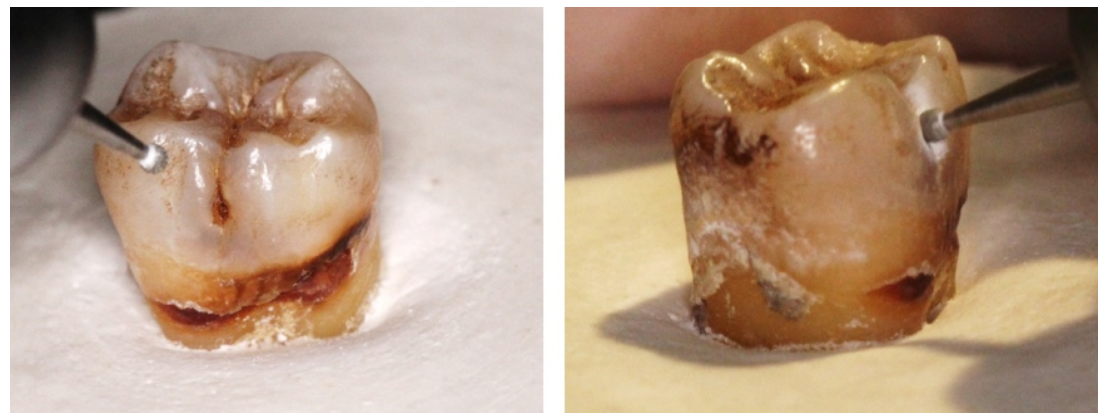

Figura 2: Acesso a cavidade de cárie Fonte: autores, 2021.

- Remoção de tecido cariado com auxílio de brocas em baixa rotação, nas paredes circundantes seguido do uso de colheres de dentina para a parede de fundo;
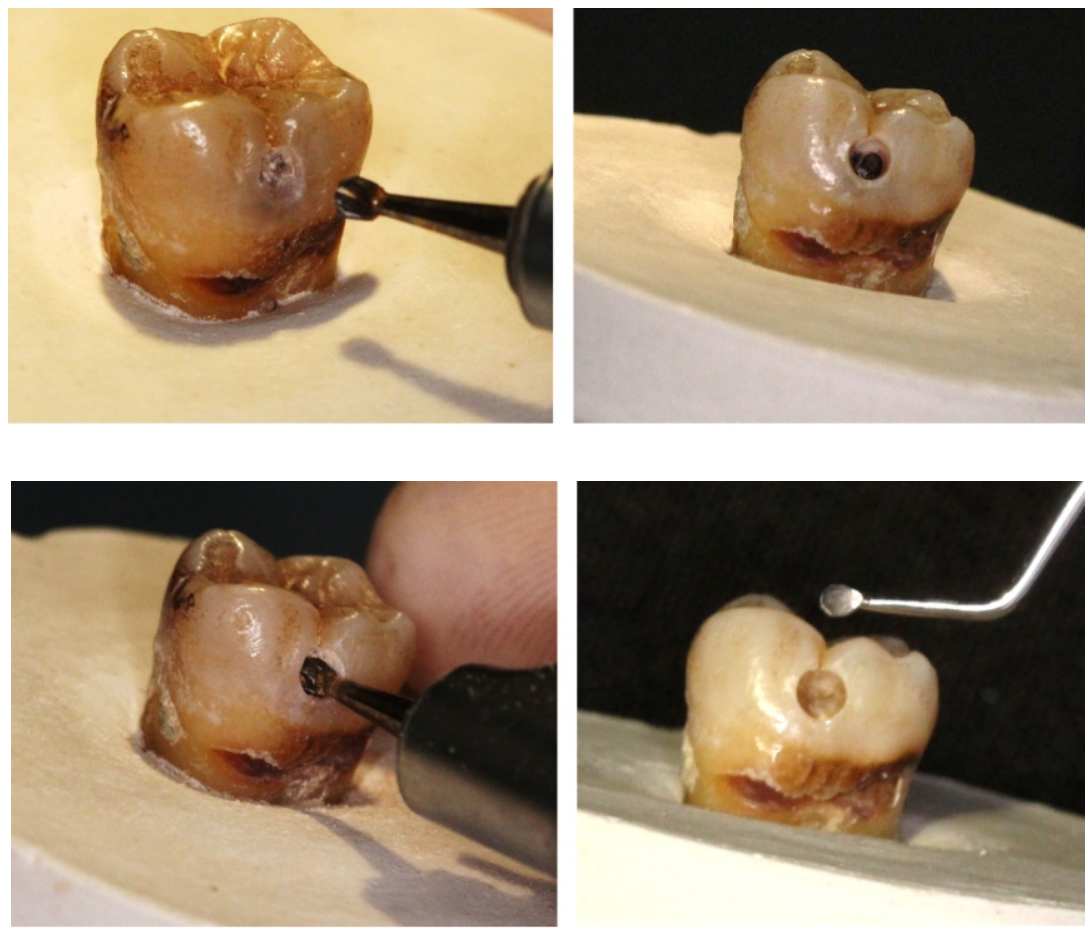

Figura 3: Remoção de tecido cariado Fonte: autores, 2021.

- Posteriormente a checagem da consistência do remanescente dentário com o uso de uma sonda de ponta romba

- Regularização da cavidade (possíveis espículas)

- Profilaxia da cavidade com pedra pomes e água e auxílio de uma escova de Robinson 


\section{PROTOCOLO - REMOÇÃO PARCIAL DO TECIDO CARIADO}

Material necessário:

- Lençol de borracha;

- Rolo de cada de matriz metálica de $5 \mathrm{~mm}$ e $7 \mathrm{~mm}$;

- Caneta para marcação do lençol;

- Vaselina;

- Lubrificantehidrossolúvel;

- Caixa de tiras de lixa;

- Rolo de fio Dental;

- Gases (1 pacote);

- Rolo de algodão;

Instrumental necessário

- Arco de Young Espátula de ponta romba;

- Grampos: 200 ao 205 molares, 206 ao 209 pré-molares, 210 ao 212 Anterior, 212 L, $212 \mathrm{R}, 26$, W8A;

- Colheres de dentinas $\mathrm{n} 05,11 \frac{1}{2}, 17,19,20$;

- Brocas de aço esféricas números 2, 3, 4, 5 e 6;

- Pontas diamantadas esféricas 1011, 1012, 1014;

- Ponta diamantada tronco cônica 3139;

- Perfurador de borracha;

- Pinça porta grampos;

- Tesoura;

- Recortadores de margem gengival;

- Seringa carpule;

- Escova de Robinson para cavidade;

- Kit clínico: bandeja, sonda exploradora número 5, sonda periodontal OMS e espelho bucal;

- Posicionador radiográfico e colgadura (a depender da demanda dos pacientes).

\section{Passo a passo}

- Inspeção visual do elemento com cárie, diagnóstico adequado (visual e radiográfico) seguido de anestesia intraoral;

- Realização do Isolamento absoluto ou relativo;

- Acesso a cavidade de cárie, se tiver a presença de esmalte, usa pontas esféricas diamantadas para acesso da cavidade;

- Inicia-se removendo a dentina necrótica superficial das paredes circundantes, utilizando broca esférica em baixa rotação, e o tecido cariado mais amolecido da parede pulpar deve ser removido com o auxílio de colher de dentina para evitar uma possível exposição pulpar;

- Posteriormente a checagem da consistência do remanescente dentário com o uso de uma sonda de ponta romba;

- Regularização da cavidade (possíveis espículas);

- Profilaxia da cavidade com pedra pomes e água e auxílio de uma escova de Robinson. 


\section{REFERÊNCIAS}

1. Barros, M. M. A. F., Rodrigues, M. I. D. Q., Muniz, F. W. M. G., \& Rodrigues, L. K. A. (2019). Selective, stepwise, or nonselective removal of carious tissue: which technique offers lower risk for the treatment of dental caries in permanent teeth? A systematic review and meta-analysis. Clinical oral investigations, 1-12.

2. Franzon, R., Opdam, N. J., Guimarães, L. F., Demarco, F. F., Casagrande, L., Haas, A. N., \& Araujo, F. B. (2015). Randomized controlled clinical trial of the 24months survival of composite resin restorations after one-step incomplete and complete excavation on primary teeth. Journal of dentistry, 43(10), 1235-1241.

3. Khokhar, M., \& Tewari, S. (2018). Outcomes of partial and complete caries excavation in permanent teeth: A 18 month clinical study. Contemporary clinical dentistry, 9(3), 468.

4. Maltz, M., Koppe, B., Jardim, J. J., Alves, L. S., de Paula, L. M., Yamaguti, P. M., ... \& Mestrinho, H. D. (2018). Partial caries removal in deep caries lesions: a 5year multicenter randomized controlled trial. Clinical oral investigations, 22(3), 1337-1343.

5. MALTZ, Marisa et al. Cariologia: Conceitos Básicos, Diagnóstico e Tratamento Não Restaurador: Série Abeno: Odontologia Essencial-Parte Clínica. Artes Medicas, 2016.

6. Singh, S., Mittal, S., \& Tewari, S. (2019). Effect of Different Liners on Pulpal Outcome after Partial Caries Removal: A Preliminary 12 Months Randomised Controlled Trial. Caries research, 53(5), 491-498. 


\section{Capitulo5}

\section{PROTEÇÃO DO COMPLEXO DENTINO-PULPAR}

polpa dental é um órgão constituído por tecido conjuntivo frouxo especializado, substância amorfa, fibras, vasos e nervos, que está circundada por dentina e esmalte. Tem por funções a formação e nutrição da dentina, bem como inervação e defesa do dente ${ }^{1,2}$. A polpa pode sofrer estímulos de diferentes naturezas, como físicos (calor, frio e eletricidade); mecânicos (compressão e corte) e químicos (substância com potencial quimiotáxico) que podem ser reversíveis ou irreversíveis ${ }^{2,3}$. o cirurgião dentista tem que ter conhecimento a respeito do tipo de comprometimento pulpar, por meio da origem e duração da dor, para lançar mão da melhor escolha terapêutica² ${ }^{2}$.

A proteção do complexo dentino pulpar vai consistir na aplicação de materiais com intuito de manter a vitalidade pulpar. A escolha desses materiais vai depender de fatores como profundidade da cavidade, idade do paciente e condição pulpar ${ }^{2,3}$.

Os materiais restauradores devem ter alguns requisitos como

- $\quad$ Ser bom isolante térmico e elétrico;

- Ter propriedades bactericidas e/ou bacteriostáticas;

- Possuir adesão às estruturas dentárias;

- Estimular reparação das funções biológicas da polpa;

- $\quad$ Favorecer a formação de dentina terciária;

- Ser inócuo a polpa;

- Biologicamente compatível;

- $\quad$ Apresentar boa resistência mecânica;

- Inibir a penetração dos íons metálicos;

- $\quad$ Evitar a penetração de bactérias ${ }^{3}$. 
Como não há nenhum material que apresente todas as características ideais, se faz necessário o uso em associação 2,3 .

Os materiais protetores do complexo dentino-pulpar podem ser classificados como seladores (vernizes e sistemas adesivos), forradores (hidróxido de cálcio, agregado de tri-óxido mineral -MTA- e óxido de zinco e eugenol) e bases cavitárias (ionômero de vidro e óxido de zinco e eugenol) ${ }^{3}$.

\section{AGENTES SELADORES}

Apresentam-se como uma película protetora de aproximadamente 1-50 $\mu \mathrm{m}$ de espessura ${ }^{3}$. Tem por função selar a embocadura dos túbulos dentinários para reduzir a sensibilidade e penetração dos fluidos e bactérias ${ }^{3}$.

\section{VERNIZES CAVITÁRIOS}

Apresentam uma baixa contração de presa, podendo ser classificado em convencional e modificado. Geralmente estão disponíveis em dois frascos, o que contém o verniz propriamente dito e outro com o solvente ${ }^{3}$. Quando aplicados na cavidade, o solvente evapora-se deixando uma película forradora semipermeável, vedando os túbulos dentinários ${ }^{3}$.

O verniz cavitário convencional é composto por uma resina natural (Copal) e o modificado, por resina sintética (polímeros e aminas). O solvente orgânico pode ser do tipo acetona, clorofórmio ou éter ${ }^{3}$.

Os vernizes modificados apresentam, em sua composição, hidróxido de cálcio e óxido de zinco, com funções terapêuticas ao dente, além disso, desempenham o papel de aumentar a resistência da película, podendo conter também, diiodotimol e o flúor, com ação bacteriostática ${ }^{3}$.

Esses materiais não devem ser utilizados quando a restauração definitiva for resina composta, pois irá inibir a polimerização adequada da mesma ${ }^{3}$.

Apresentam as seguintes propriedades:

- Proteção parcial contra choques termoelétricos, reduzindo a dor pós operatória;

- Inibição de penetração de íons metálicos na dentina;

- Redução da infiltração de bactérias e toxinas na dentina e polpa;

- Baixa solubilidade aos fluidos orais ${ }^{3}$. 


\section{Manipulação dos vernizes cavitários convencionais}

Inicialmente, deve-se agitar bastante o frasco e esse deve ficar aberto por o menor tempo possível, para que o solvente não se volatilize. A aplicação é feita com um pincel ou microbrush. Aplica-se no mínimo duas camadas em todas as paredes internas da cavidade, em um único sentido para gerar uma película uniforme. Entre uma camada e outra, deve-se secar com um jato de ar (30 segundos) para acelerar a evaporação do solvente ${ }^{3}$.

Nas cavidades para amálgama onde colocou-se um agente forrador, aplica-se o verniz apenas nas paredes laterais ${ }^{3}$.

\section{SISTEMAS ADESIVOS}

São materiais que apresentam em sua composição monômeros resinosos, solvente orgânico (água, álcool ou cetona), iniciadores, inibidores e carga. Podem ser classificados como sistemas adesivos convencionais e autocondicionantes. Esses vão interagir com o dente formando a camada híbrida ${ }^{3}$. A aplicação desse material não deve ser feita diretamente em tecido pulpar ou cavidades muito profundas pois são materiais potencialmente irritantes, assim irá ocorrer a soma de estímulos a polpa que já se encontra em situação adversa ${ }^{2}$.

\section{AGENTES FORRADORES}

Os agentes forradores desempenham funções como estímulo da formação de ponte de dentina e proteção da região mais profunda da dentina contra penetração de subprodutos dos materiais restauradores. Apresentam-se como uma fina camada de 0,2 a $1 \mathrm{~mm}$ de espessura. São eles: cimento hidróxido de cálcio, MTA e óxido de zinco e eugenol ${ }^{3}$.

\section{HIDRÓXIDO DE CÁLCIO}

Podem se apresentar de 3 formas: pó, pasta e cimento. Devem ser utilizados quando há exposição de tecido pulpar, pó ou pasta, ou quando a cavidade está muito profunda com risco de exposição. Quando em contato com a polpa, o hidróxido de cálcio $[\mathrm{Ca}(\mathrm{OH}) 2]$ se dissocia em $\mathrm{Ca} 2+$ e OH-, aumentando o pH e induzindo uma cauterização química superficial no tecido pulpar, gerando um meio propício para a deposição de mineral, levando a formação da "ponte de dentina" 2,3 . 
Os cimentos de hidróxido de cálcio podem se apresentar como uma ou duas bisnagas. Quando em duas pastas, umas delas é denominada pasta-base (55\% de $\mathrm{Ca}(\mathrm{OH}) 2,9-13 \%$ de $\mathrm{ZnO}, 1 \%$ de estearato de $\mathrm{Zn}$ e $34-39 \%$ de etiltolueno sulfonamida) e pasta-catalizadora (38-43\% de dissilicato butileno glicol ou polimetileno de metila e pigmentos). Os cimentos podem se apresentar na forma fotopolimerizável, onde sua reação de presa é ativada por luz visível 2,3 . O hidróxido de cálcio apresentam algumas propriedades como:

- $\quad \mathrm{pH}$ básico, no entanto os cimento possuem o pH menor que pó e pasta, possuindo menor efeito cáustico;

- Bactericida e bacteriostático;

- Baixa resistência mecânica;

- $\quad$ Alta solubilidade 2,3.

\section{Manipulação do hidróxido de cálcio}

- Pasta/pó

São utilizados em cavidades com exposição pulpar. No caso da aplicação somente do pó, a umidade da exposição pulpar facilitará a permanência do pó na cavidade. Para obter-se a pasta, o pó deve ser incorporado ao soro fisiológico até gerar uma consistência pastosa, devendo ser inserida na cavidade com auxílio do aplicador de hidróxido de cálcio ${ }^{3}$.

\section{- Cimento de presa química}

São utilizados quando não há exposição pulpar. Quantidades iguais de pasta base e catalisadora (1:1) devem ser adicionadas em uma placa de vidro ou em um bloco de espatulação que acompanha o material. O tempo de espatulação é de 10 segundos, ao final a mistura deve se apresentar bem homogênea, devendo ser realizada com o aplicador de hidróxido de cálcio. O tempo de trabalho é de 2-3 minutos, sob condições normais de umidade e temperatura ${ }^{3}$. Com o auxílio do instrumento de inserção, deve ser aplicado no local mais profundo da cavidade apenas. Cerca de 7 minutos esse material já tem resistência suficiente para suportar uma condensação de amálgama, por exemplo ${ }^{3}$.

\section{- Cimento fotopolimerizável}

Apresenta-se em pasta única, onde deve ser inserida na cavidade e fotopolimerizada de acordo com as recomendações do fabricante, mas geralmente 20 segundos. 


\section{AGREGADO TRIÓXIDO MINERAL (MTA)}

Pó na cor branca ou cinza, composto por óxidos minerais e íons. Material altamente biocompatível. Pode ser utilizado em caso de exposição pulpar, atuando através da formação de uma "ponte de dentina". Tem propriedades antimicrobianas. E seu mecanismo de ação é através de doação de íons de cálcio próximos aos tecidos pulpares, que auxiliam na mineralização dessa região. Apresentam como vantagem uma baixa solubilidade 3,4 .

\section{Manipulação do MTA}

Proporção pó/líquido (água destilada) é variável de acordo com o fabricante. O tempo de presa inicial é de 2:30 horas e o final se dá entre 3 a 4 horas ${ }^{3}$.

\section{AGENTES PARA BASE}

Apresentam-se normalmente em forma de pó e líquido, que depois de manipulados formam uma película de aproximadamente $1 \mathrm{~mm}$ de espessura. Dentre eles, podemos destacar o cimento fosfato de zinco (em desuso para tal função), cimento óxido de zinco e eugenol e o cimento ionômero de vidro. Vão ter como funções principais proteção dos agentes forradores, redução da espessura do material restaurador definitivo e proteção contra estímulos ${ }^{3}$.

\section{CIMENTO ÓXIDO DE ZINCO E EUGENOL}

Além de bases, apresentam outras indicações como: material restaurador provisório, cimento cirúrgico, cimento endodôntico, agente de cimentação provisória e material de moldagem. Podem ser classificados quanto ao seu tipo:

Tipo I-cimentação provisória (pasta/pasta)

Tipo II-cimentação definitiva (pasta/pasta ou pó/líquido)

Tipo III - restaurações provisórias e bases (pó/líquido)

Tipo IV - forramento (pasta/pasta ou pó/líquido), nessa função apenas quando não há exposição pulpar.

Sua reação de presa vai ocorrer por meio de quelação, onde o eugenol irá ser consumido completamente e haverá partículas não reagidas circundadas por matriz de eugenolato de zinco. A água acelera a reação.

Esses materiais não podem ser utilizados em conjunto com a resina composta, devido ao eugenol que irá inibir a polimerização adequada das mesmas 2,3 . 


\section{Manipulação do óxido de zinco e eugenol}

-pasta/pasta

A semelhança de como foi descrito com o hidróxido de cálcio, e sua inserção na cavidade deverá ocorrer com espátula $n$ ํㅜㄴ ${ }^{3}$.

\section{-pó/líquido}

Em geral a proporção vai ser de uma parte de pó para uma de líquido (1:1). Deve-se agitar o frasco do pó antes da sua manipulação, e essa deverá ser feita com a espátula de número 36. As poções devem ser dispensadas em uma placa de vidro. Divide-se o pó em 3 partes (50,25 e 25\%), em seguida incorpora-se a maior parte do pó ao líquido, seguida das demais. $O$ tempo de manipulação deve ser de 45 segundos a 1 minuto, 15 segundos por porção, aproximadamente. Deve-se usar uma área mínima da placa, para que o líquido não seja desperdiçado. A consistência final deve-se parecer com "massa de vidraceiro" ou massa de pão ${ }^{3}$. Leva-se a cavidade com o auxílio de uma espátula de inserção nำ 1 (Ward $)^{3}$.

\section{CIMENTO FOSFATO DE ZINCO}

Como já dito anteriormente, esses materiais não são mais utilizados como base, no entanto são amplamente utilizados como agentes cimentantes. Apresenta-se na forma de pó (óxido de zinco e óxido de magnésio) e líquido (solução tamponada de ácido fosfórico). Apresenta alta resistência a compressão, apresentando como desvantagem solubilidade e desintegração.

\section{Manipulação do cimento fosfato de zinco}

Deve ser feita sob uma placa de vidro, onde deve-se colocar o pó e em seguida o líquido, de acordo com as recomendações do fabricante. A manipulação deverá ser realizada com a espátula no 24. Divide-se o pó em 5 porções e inicia-se a espatulação da menor porção para a maior, totalizando 90 segundos, até obterse uma consistência que ao levantar a espátula, forme-se um fio de 3 a 4 centímetros. A massa obtida é colocada na peça protética e levada à boca para realização da cimentação.

\section{CIMENTO IONÔMERO DE VIDRO}

É amplamente utilizado como base cavitária, apresenta boa adesão ao tecidos dentais, é bacteriostático e bactericida, possui o coeficiente de expansão térmico e linear semelhante ao do dente, no entanto detalhes sobre suas propriedades vão ser explicadas na prática seguinte. 


\section{SELEÇÃO DOS MATERIAIS DE ACORDO COM A PROFUNDIDADE DA CAVIDADE}

A avaliação da profundidade da cavidade trata-se de uma conduta clínica importante para a escolha do tratamento ideal, que pode culminar no sucesso do procedimento de proteção do complexo dentino-pulpar.

- Cavidade rasa

É uma cavidade na qual existe um remanescente entre 3,0 a 5,0 mm de espessura. Deve-se usar um material selador seguido de restaurador definitivo ${ }^{2}$.

\section{- Cavidade média}

Aproximadamente 1,5 a 0,5 mm de dentina remanescente. Usa-se uma base, seguido de um selador e material definitivo ${ }^{2}$.

\section{- Cavidade profunda}

Apresenta 0,5 a 0,25 mm de remanescente de dentina. Sem exposição pulpar deve-se lançar mão de um procedimento restaurador indireto. Dessa forma aplica-se o agente forrador, seguido de base, selador e material restaurador definitivo ${ }^{2}$.

\section{- Cavidade muito profunda com exposição pulpar}

Com 0,01 mm de espessura de dentina. Nesses tipos de situações, deve-se limpar a cavidade, aplicar o material forrador (muitas vezes o hidróxido de cálcio pó ou pasta pode ser bem aplicado), seguido de base, selador e restauração definitiva ${ }^{2}$. 


\section{REFERÊNCIAS}

1. CONCEIÇÃO, Ewerton N. Dentística: estética e saúde. 2. ed. São Paulo. Artmed, 2007.

2. PEREIRA, José Carlos. Tratamentos conservadores da vitalidade pulpar: princípios biológicos e clínicos. Biodonto. Baurú, world News, v.2 , n. 3, maio/junho, 2004.

3. REIS, Alessandra ; LOGUERCIO, Alessandro D. Materiais Dentários Diretos: dos fundamentos à aplicação clínica. Santos. Santos editora, 2007.

4. DUBE K.; JAIN P.; RAI A.; PAUL B. Preventive endodontics by direct pulp capping with restorative dentin substitute-biodentine: A series of fifteen cases. Indian Journal of Dental Research, v.29, n. 3, junho, 2018. 


\section{Capitulo6}

\section{TÉCNICAS DE PROTEÇÃO DO COMPLEXO DENTINOPULPAR}

tualmente a odontologia restauradora atua com princípios minimamente invasivos com o objetivo de preservar ao máximo os tecidos dentários ${ }^{1,4,5}$. Quando se trata de técnicas de proteção do complexo dentinopulpar, devese ter muito cuidado para que a terapêutica não interfira na manutenção da vitalidade pulpar 2,4 .

Tendo em vista sua importância, existem tratamentos conservadores que visam manter a sua integridade sem precisar intervir nela, onde serão descritos mais detalhadamente abaixo o capeamento pulpar direto, capeamento pulpar indireto e tratamento expectante. Vale lembrar que antes da intervenção, existem alguns fatores à serem observados, tais como: grau de comprometimento pulpar e profundidade lesão 2,5.

\section{CAPEAMENTO PULPAR INDIRETO}

O capeamento pulpar indireto é indicado quando a cavidade é muito profunda mas não se tem exposição pulpar. Nesse caso, a camada mais profunda de dentina remanescente é coberta com um material biocompatível com a finalidade de paralisar o processo carioso através da formação de dentina reparadora preservando a vitalidade pulpar ${ }^{1,2}$.

Material necessário

- $\quad$ Caixa de lençol de borracha;

- Matriz metálica de $5 \mathrm{~mm}$ e $7 \mathrm{~mm}$;

- $\quad$ Caneta para marcação do lençol;

- Vaselina;

- Lubrificante hidrossolúvel; 
- $\quad$ Caixa tiras de lixa;

- $\quad$ Caixa de fio dental;

- Gazes estéreis;

- $\quad$ Rolo de algodão estéril;

- Hidróxido de cálcio (cimento);

- $\quad$ Soro fisiológico.

Instrumental necessário

- Arco de Young;

- Grampos para isolamento absoluto 210, 211, 212, 26, W8A, 202, 203, 204, 205, 206 e 209;

- Aplicador de hidróxido de cálcio;

- Tesoura;

- Espátula de inserção número 1;

- Seringa carpule;

- Escova de Robinson;

- Kit clínico: bandeja, sonda exploradora número 5, sonda periodontal OMS e espelho bucal;

- Posicionador radiográfico;

- Colgadura;

- Espátula no24;

- Placa de vidro;

Passo a passo

- O dente precisa estar isolado e o tecido cariado removido;

- Realizar a profilaxia da cavidade com pedra pomes e água seguida de lavagem abundante;

- Enxugar a cavidade com algodão estéril;

- Iniciar a manipulação do cimento hidróxido de cálcio com as espátula no 24 na proporção de 1:1 (pasta base/catalizadora) manipulando por 30 segundos;

- Inserir o cimento de hidróxido de cálcio com o aplicador de hidróxido de cálcio sob as áreas de maior profundidade da cavidade;

- Em seguida aplica-se um material base cavitário (ionômero de vidro) seguido de restauração definitiva do material de escolha;

- Após o término da restauração, radiografa-se para proservação. 


\section{CAPEAMENTO PULPAR DIRETO}

Já o capeamento pulpar direto é indicado quando se tem exposição pulpar, onde se faz uso de um revestimento biológico sobre a área que foi exposta para que posteriormente não possam surgir complicações endodônticas ou sensibilidade pós-operatória1,2.

\section{CAPEAMENTO DIRETO}

Material necessário

- $\quad$ Caixa de Lençol de borracha;

- Matriz metálica de $5 \mathrm{~mm}$ e $7 \mathrm{~mm}$;

- $\quad$ Caneta para marcação do lençol;

- Lubrificante hidrossolúvel;

- $\quad$ Caixa tiras de lixa;

- Rolo de fio Dental;

- Gazes estéreis;

- $\quad$ Rolo de algodão estéril;

- Hidróxido de cálcio (cimento);

- Hidróxido de cálcio (pó);

- $\quad$ Soro fisiológico.

Instrumental necessário

- Arco de Young;

- Grampos para isolamento absoluto 210, 211, 212, 26, W8A, 202, 203, 204, 205, 206 e 209;

- Aplicador de hidróxido de cálcio;

- Tesoura;

- Espátula de inserção número 1;

- Seringa carpule;

- Escova de Robinson;

- Kit clínico: bandeja, sonda exploradora número 5, sonda periodontal OMS e espelho bucal;

- Posicionador radiográfico Colgadura (demanda do paciente);

- Espátula n24;

- 01 Placa de vidro

- 01 Porta amálgama. 
Passo a passo

- O dente deverá estar isolado e com a remoção do tecido cariado;

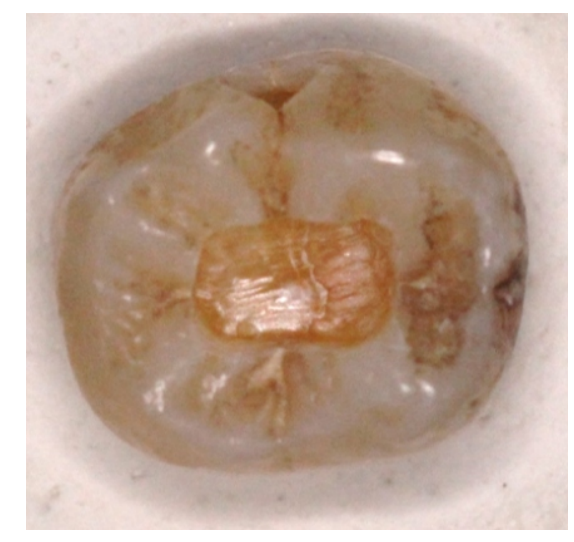

Figura 1: 0 dente deverá estar isolado Fonte: autores, 2021.

- Após a exposição acidental do tecido pulpar, deve-se observar se o sangramento é indicativo de boa recuperação pulpar;

- Limpar a cavidade e fazer a hemostasia com água de hidróxido de cálcio em uma pelota de algodão estéril (4 a 8 minutos);

- Enxugar a cavidade com algodão estéril e verificar se o sangramento foi controlado;

- Manipular com uma espátula no 24 o pó de hidróxido de cálcio com o soro até formar uma pasta, em uma placa de vidro;

- Inserir com o porta amálgama a pasta em cima da exposição pulpar;

- Iniciar a manipulação do cimento hidróxido de cálcio com as espátula no 24 na proporção de 1:1 (pasta base/catalizadora) - 30 segundos de manipulação;
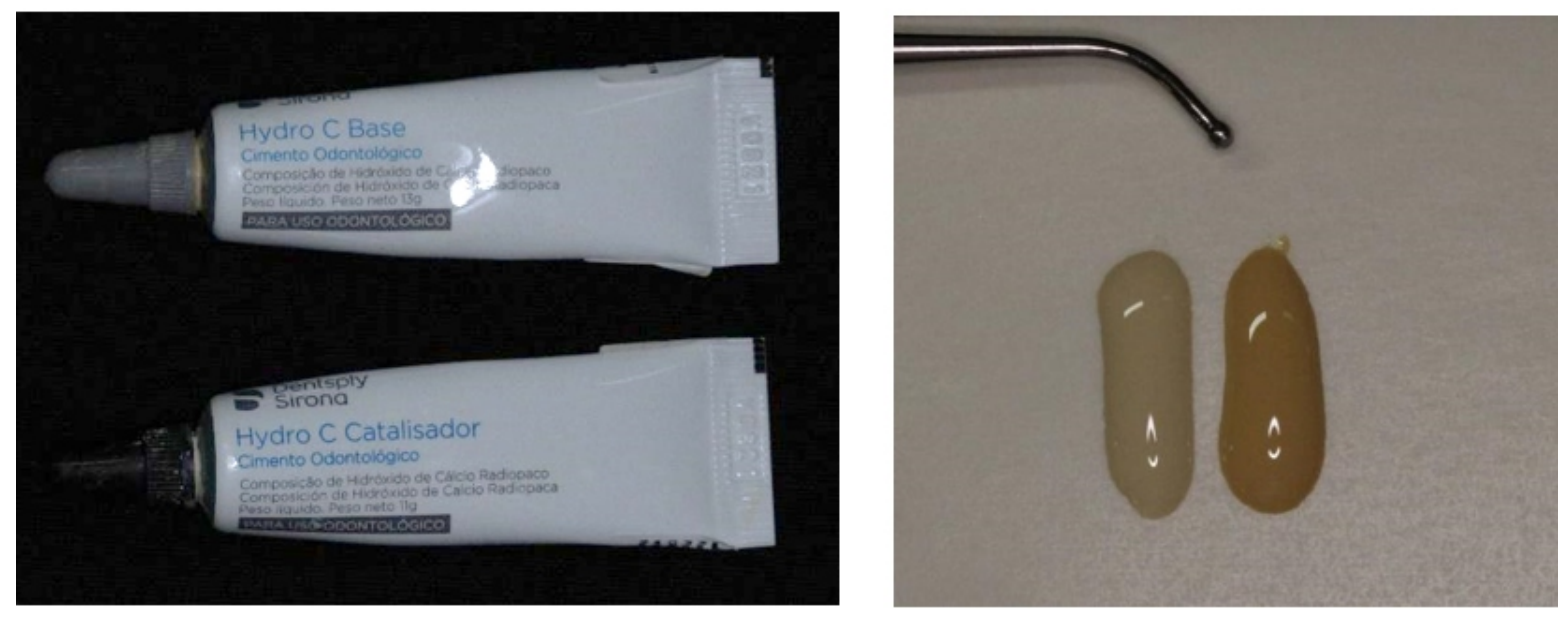

Figura 2: Manipulação do cimento hidróxido de cálcio Fonte: autores, 2021. 
- Inserir o cimento de hidróxido de cálcio com o aplicador de hidróxido de cálcio sob a pasta anteriormente colocada na exposição pulpar;
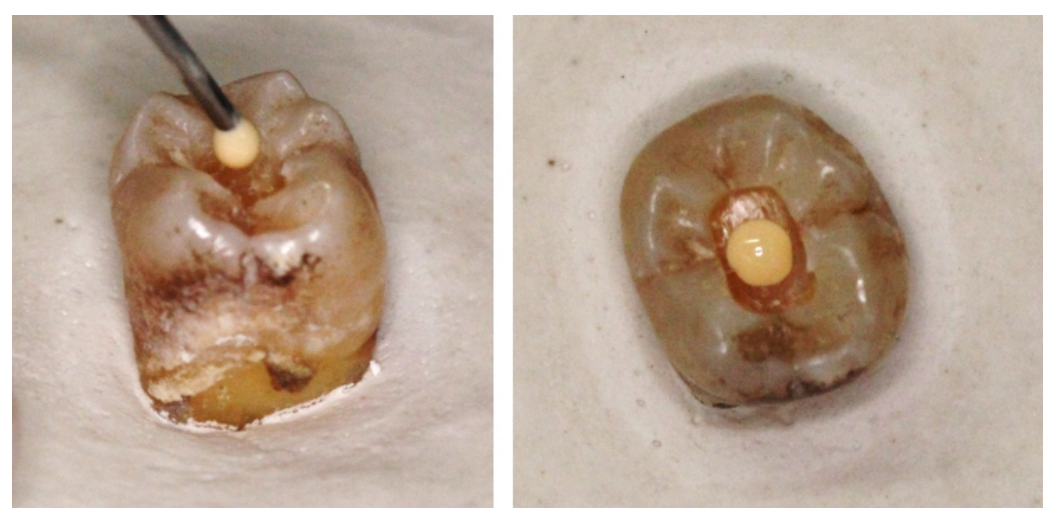

Figura 3: Inserir o cimento de hidróxido de cálcio Fonte: autores, 2021.

- Em seguida aplica-se um material base cavitário (cimento ionômero de vidro), seguido do material restaurador definitivo respectivo de cada caso;

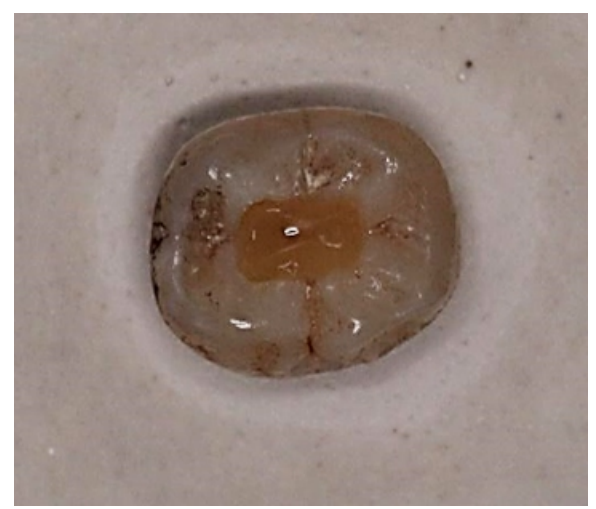

Figura 4: Aplicar material base cavitário Fonte: autores, 2021.

- Após o término da restauração, radiografa-se e acompanha-se por 90 dias.

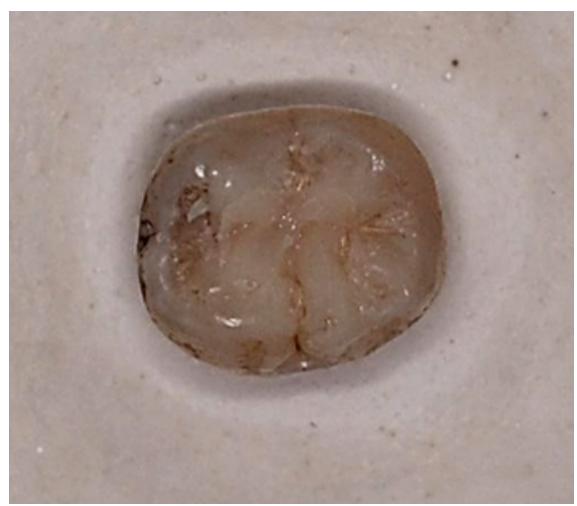

Figura 5: Término da restauração Fonte: autores, 2021. 


\section{TRATAMENTO EXPECTANTE}

O tratamento expectante é indicado em casos onde a lesão é muito profunda e o risco de exposição pulpar é muito alto, porém só deve ser realizado em pacientes jovens e com um bom prognóstico. Esse tratamento é realizado em 2 sessões, e tem como principal objetivo bloquear os estímulos irritantes, interromper a atividade bacteriana, remineralizar a dentina afetada e sadia, além de estimular a formação de dentina terciária 3,4 .

Nesse caso são utilizados materiais que estimulem a formação de dentina, sendo os mais comuns o cimento de hidróxido de cálcio e o ionômero de vidro. Após a primeira sessão, deve-se avaliar radiograficamente após 60 dias se houve formação de pontes de dentinas e remineralização do tecido afetado, se sim, em uma segunda sessão é feita a intervenção onde é removido todo o tecido cariado seguido do procedimento de proteção normal do complexo dentinopulpar ${ }^{3,4}$.

\section{TRATAMENTO EXPECTANTE (PROTEÇÃO DO COMPLEXO DENTINOPULPAR)}

Material necessário

- $\quad$ Caixa de Lençol de borracha;

- Matriz metálica de $5 \mathrm{~mm}$ e $7 \mathrm{~mm}$;

- $\quad$ Caneta para marcação do lençol;

- Vaselina;

- Lubrificante hidrossolúvel;

- Caixa de tiras de lixa;

- Fio dental;

- Gazes estéreis;

- $\quad$ Rolo de algodão estéril;

- Hidróxido de cálcio (pó);

- Soro fisiológico;

- $\quad$ Cimento ionômero de vidro;

- $\quad$ Filme radiográfico.

Instrumental necessário

- Arco de Young;

- Grampos para isolamento absoluto 210, 211, 212, 26, W8A, 202, 203, 204, 205, 206 e 209;

- Aplicador de hidróxido de cálcio;

- Tesoura;

- Espátula de inserção número 1;

- Seringa carpule;

- Escova de Robinson; 
- Kit clínico: bandeja, sonda exploradora número 5, sonda periodontal OMS e espelho bucal;

- Kit de posicionador radiográfico e colgadura;

- Espátula n24;

- Placa de vidro;

- Colheres de dentinas $n=5,11 \frac{1}{2}, 17,19$ e 20;

- Brocas de aço esféricas números 2, 3, 4, 5 e 6.

Passo a passo

- O dente deverá estar isolado e o tecido cariado das paredes circundantes removido;

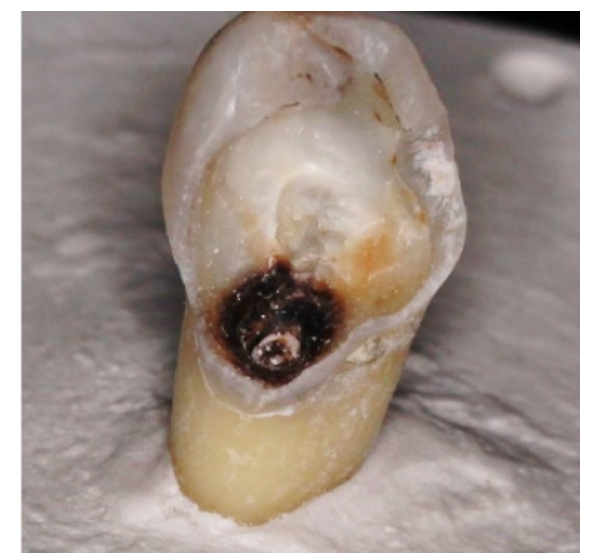

Figura 6: 0 dente deverá estar isolado Fonte: autores, 2021.

- Realizar a radiografia inicial;

- Remove-se todo o tecido cariado infectado de consistência amolecida, com auxílio de colheres de dentinas e brocas esféricas;

- Preserva-se o tecido afetado por cárie;

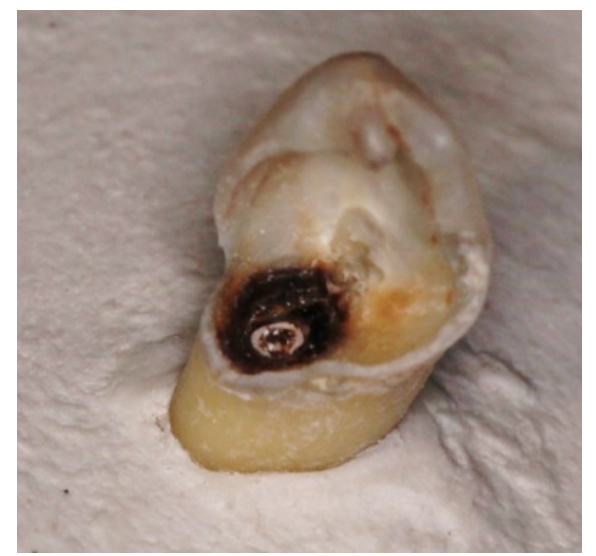

Figura 7: Remoção de todo o tecido cariado infectado Fonte: autores, 2021.

- Lavagem com solução de hidróxido de cálcio, pode fazer uso de seringa ou embebição com pelota de algodão estéril; 
- Enxugar a cavidade com algodão estéril;

- Iniciar a manipulação do pó de hidróxido de cálcio e soro fisiológico com a espátula nํ 24, até obter uma consistência de pasta;

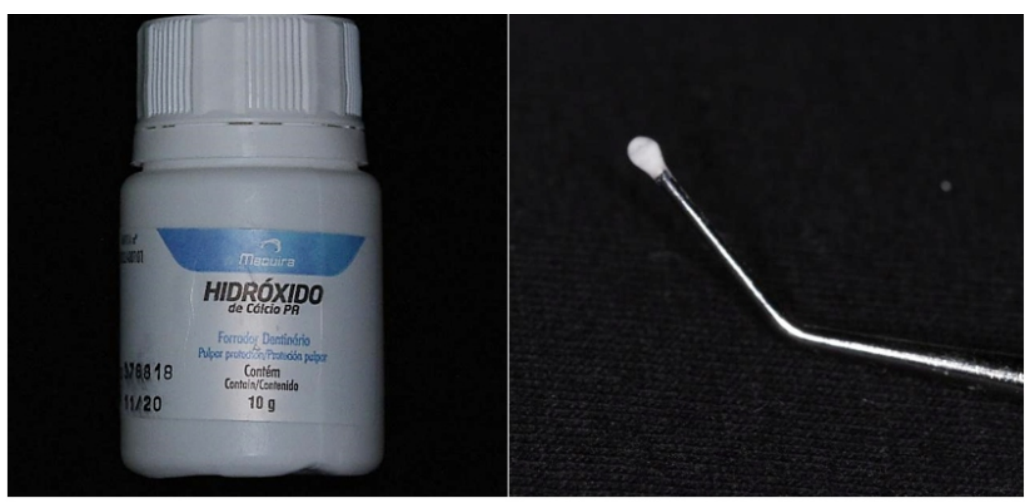

Figura 8: Pó de hidróxido de cálcio e espátula no 24 Fonte: autores, 2021

- Inserir a pasta de hidróxido de cálcio na parede de fundo da cavidade;

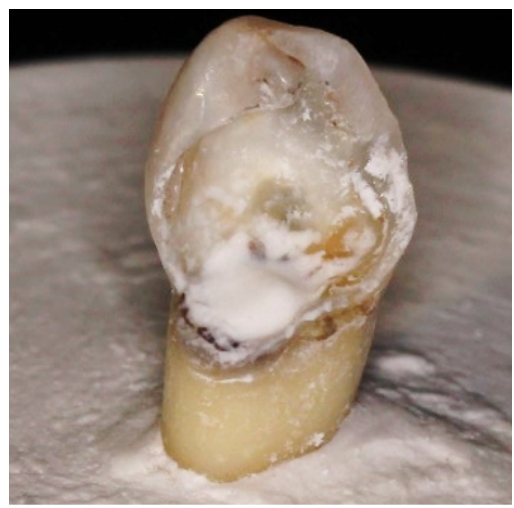

Figura 9: Inserir a pasta de hidróxido de cálcio Fonte: autores, 2021

- Em seguida aplica-se um material base cavitário (cimento ionômero de vidro);
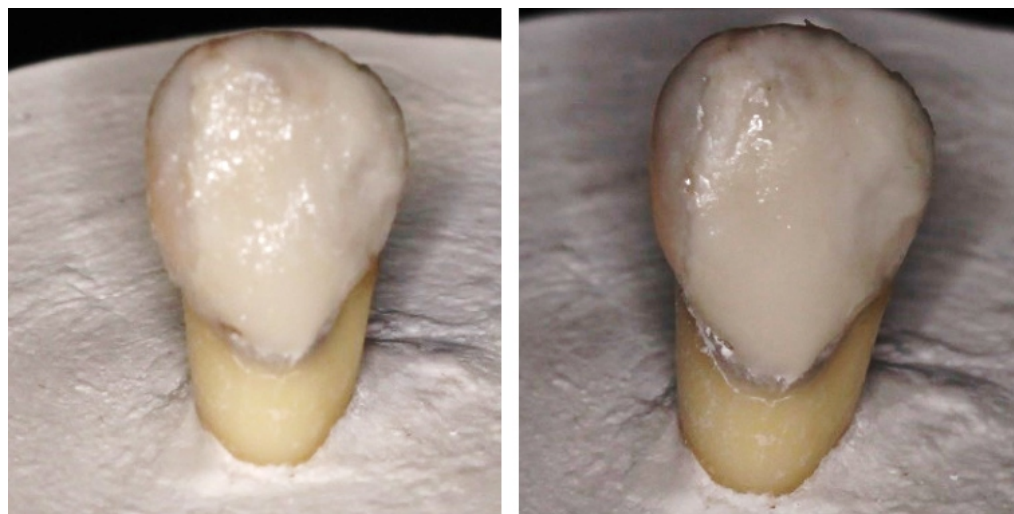

Figura 9: Inserir a pasta de hidróxido de cálcio Fonte: autores, 2021 
- Após o término da restauração, radiografa-se para proservação (espera-se cerca de 45 dias 60 a dias);

- Depois desse período realiza-se uma nova radiografia afim de ver a formação de dentina terciária e realização dos testes de vitalidade pulpar;

- Remove-se todo o material remanescente de cárie, se necessário;

- Inicia-se a manipulação do cimento hidróxido de cálcio com as espátula no 24 na proporção de 1:1 (pasta base/catalisadora) - 30 segundos de manipulação;

- Inserir o cimento de hidróxido de cálcio com o seu aplicador sob as áreas de maior profundidade da cavidade;

- Em seguida aplica-se um material base cavitário (cimento ionômero de vidro), seguido de restauração definitiva do material de escolha. 


\section{REFERÊNCIAS}

1. ANUSAVICE, Kenneth J. Phillips materiais dentários. Elsevier Brasil, 2013.

2. CARVALHO, Danielle Pereira de; ANJOS NETO, Domingos Alves dos. TRATAMENTOS CONSERVADORES DA POLPA DENTAL (UNIT-SE). 2017.

3. MONDELLI, José et al. Fundamentos de dentística operatória. 2018.

4. REIS, Alessandra; LOGUERCIO, Alessandro Dourado. Materiais dentários diretos: dos fundamentos à aplicação clínica. Santos, 2007. 


\section{Capitulo7}

\section{CLAREAMENTO DENTAL}

os últimos tempos a odontologia tem passado por várias mudanças, principalmente em relação à correção de fatores estéticos, como forma, tamanho, alinhamento e cor dos dentes, visando sempre a melhoria da harmonia do sorriso ${ }^{1}$. Nesse contexto, o clareamento dental é um dos procedimentos mais procurados pelos pacientes em busca de um sorriso branco e perfeito nos consultórios odontológicos. As técnicas de clareamento podem ser classificadas em dois métodos: o de consultório e o caseiro/domiciliar.

\section{AGENTES CLAREADORES E MECANISMO DE AÇÃO}

Atualmente, existem no mercado três substâncias básicas utilizadas para o clareamento dental, são elas:

- Peróxido de hidrogênio;

- Peróxido de carbamida;

- Perborato de sódio.

As moléculas de peróxido de hidrogênio são as que agem clareando os pigmentos dos dentes, sendo que as outras substâncias (peróxido de carbamida e perborato de sódio) são decompostas em peróxido de hidrogênio ${ }^{2}$.

\section{Peróxido de Hidrogênio}

Apresenta-se como um gel incolor com alto potencial oxirredutor e por isso alta capacidade de clareamento. Ele pode ser encontrado em baixas ou em altas concentrações, quando encontrado em baixas concentrações (1 a 10\%), é indicado para o método caseiro em curtos períodos (de 1 até 4 horas por dia). 
Em concentrações mais elevadas (30 a 38\%), deve ser utilizado no método de consultório, por curtos períodos (cada aplicação leva em torno de 10 a 15 minutos, totalizando cerca de 2 a 3 aplicações, por sessão de 1 hora) ${ }^{2}$.

\subsubsection{Mecanismo de Ação}

O peróxido de hidrogênio atua como um forte agente antioxidante através da formação de radicais livres, moléculas de oxigênio reativas e ânions de peróxido de hidrogênio, essas moléculas reativas atacam as longas cadeias orgânicas que compõem os pigmentos escuros, transformando-as em moléculas menores e consequentemente, menos coloridas ${ }^{2}$.

\subsection{Peróxido de Carbamida}

É frequentemente encontrado em concentrações de 10 a 37\%, quando de 10 a $16 \%$ é indicado para tratamentos caseiros durante a noite, por um período de $4 \mathrm{a}$ 8 horas. Quando em concentrações de 20 a 22\%, deve ser utilizado também no método caseiro, no entanto, por 2 a 4 horas. Em concentrações mais elevadas (acima de 30\%) deve ser usado na técnica de consultório, com tempo de aplicação em torno de uma hora, podendo variar de acordo com o fabricante ${ }^{2}$.

\subsubsection{Mecanismo de Ação}

Ao entrar em contato com a umidade, o peróxido de carbamida se dissocia em ureia (64\%) e peróxido de hidrogênio (36\%), o peróxido de hidrogênio atuará diretamente sobre os pigmentos e a ureia se dissocia em amônia (aumenta o pH, favorecendo o clareamento) e em gás carbônico (favorece o deslocamento das moléculas de pigmento) ${ }^{2}$.

\subsection{Perborato de Sódio}

O perborato de sódio apresenta-se como pó e é uma substância específica para procedimento clareador endógeno, podendo ser utilizado sozinho ou associado ao peróxido de hidrogênio, peróxido de carbamida ou à água. É aplicado dentro da câmara pulpar e fica em forma de curativo por 7 dias, para que o clareamento aconteça gradativamente ${ }^{2}$.

\subsubsection{Mecanismo de Ação}

Ao entrar em contato com a água, o perborato de sódio se decompõe, liberando metaborato de sódio, peróxido de hidrogênio e oxigênio. O peróxido de hidrogênio atua diretamente clareando os pigmentos, enquanto o oxigênio facilita o deslocamento das moléculas dos pigmentos ${ }^{2}$. 


\section{Técnica de Clareamento Dental caseiro com moldeiras}

\subsection{Material necessário}

- Equipamentos de proteção individual;

- Pedra-pomes;

- 5 medidas de pó de alginato;

- 10 medidas de gesso;

- 1 unidade de placa de acetato $(1,5 \mathrm{~mm})$;

- 2 bisnagas de gel clareador.

\subsection{Instrumental necessário}

- Kit de exame clínico;

- 1 escova de Robinson;

- 1 taça de borracha;

- 1 kit de moldeiras;

- Cubas de borracha;

- Espátula para gesso;

- Espátula para alginato;

- Plastificadora à vácuo.

\subsection{Passo a passo Clínico}

- Profilaxia dos elementos dentários com pedra-pomes e água associada a escova de Robson ou taça de borracha e análise de cor inicial dos dentes;

- Moldagem das arcadas superior e inferior com alginato;

- Moldes devem ser vazados em gesso;

- Modelos de gesso devem ser recortados em formato de $U$ ou ferradura;

- Confecção das moldeiras em uma plastificadora à vácuo;

- Os excessos da porção vestibular das moldeiras devem ser recortados de modo que permaneça uma espessura de aproximadamente $1 \mathrm{~mm}$ acima da margem cervical;

- Prova da moldeira na boca do paciente.

- Consultas de retorno periódicas devem ser agendadas 7 dias após o início do tratamento

\subsection{Instruções ao Paciente}

- Demonstrar ao paciente a quantidade de gel a ser colocada na face vestibular de cada dente; 
- Orientar o paciente que deve ser realizada higiene bucal previamente à utilização da moldeira;

- Orientar o paciente quanto à adaptação da moldeira e remoção do excesso de gel extravasado;

- O tempo de utilização da moldeira dependerá do tipo de clareador utilizado e de sua concentração. Os géis utilizados para essa técnica são peróxido de hidrogênio de concentração até 10\% (utilizar até 1 a 2 horas por dia) e o peróxido de carbamida em concentrações de $10 \%, 16 \%$ ou $22 \%$ (utilizar de 2 a 4 horas diárias).

\section{Técnica de Clareamento Dental de consultório}

\subsection{Material necessário}

- Equipamentos de proteção individual;

- Pedra-pomes;

- 1 caixa da gel clareador: peróxido de hidrogênio 35 a 38\%;

- Escala de cor;

- Lubrificante para lábios;

- 1 bisnaga de barreira gengival fotopolimerizável;

- 5 unidades de microbrush;

- 1 sugador descartável;

- Agente dessensibilizante à base de nitrato de potássio e fluoreto de sódio;

- Flúor gel neutro;

- Algodão e gaze.

\subsection{Instrumental necessário}

- Kit de exame clínico;

- 1 escova de Robinson;

- 1 taça de borracha;

- 1 afastador labial;

- 1 turbina de baixa rotação;

\subsection{Passo a passo Clínico}

- Profilaxia dos elementos dentários com pedra-pomes e água associada à escova de Robson ou taça de borracha; 


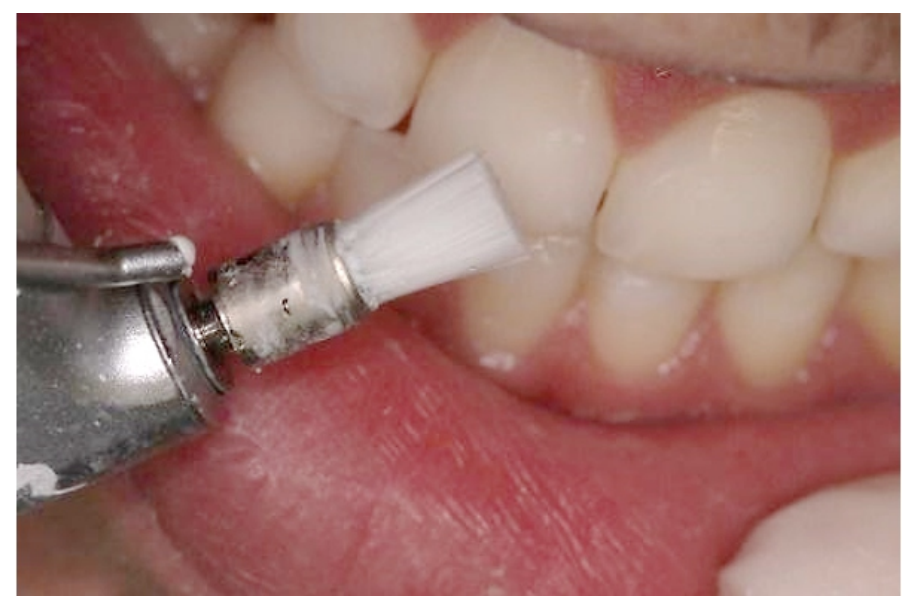

Figura 1: Profilaxia dos elementos dentários Fonte: autores, 2021

- Registro inicial da cor por meio de escala de cores associadas a fotografias;

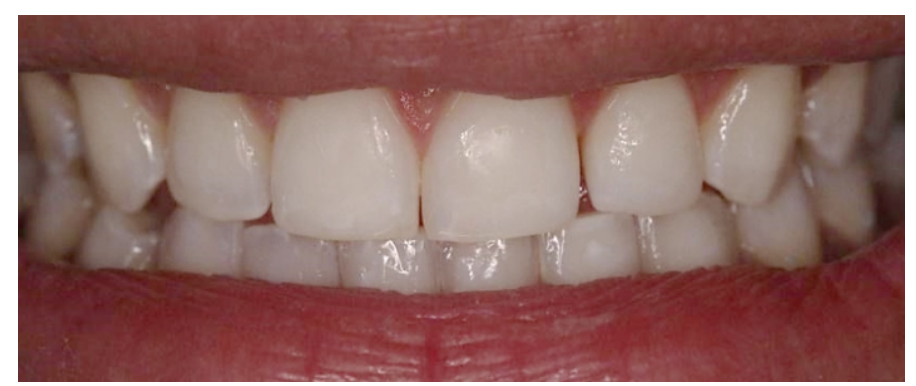

Figura 2: Registro inicial da cor por meio de escala de cores Fonte: autores, 2021

- Proteção dos tecidos moles: lubrificação dos lábios;

- Isolamento do campo operatório: isolamento com afastador labial flexível associado à barreira gengival fotopolimerizável;

- Confecção da barreira gengival: as superfícies dentárias e a gengiva marginal devem ser secas com jato de ar. Cobrir 0,5 mm da margem gengival e 0,1 a 0,2 $\mathrm{mm}$ da cervical dos dentes;

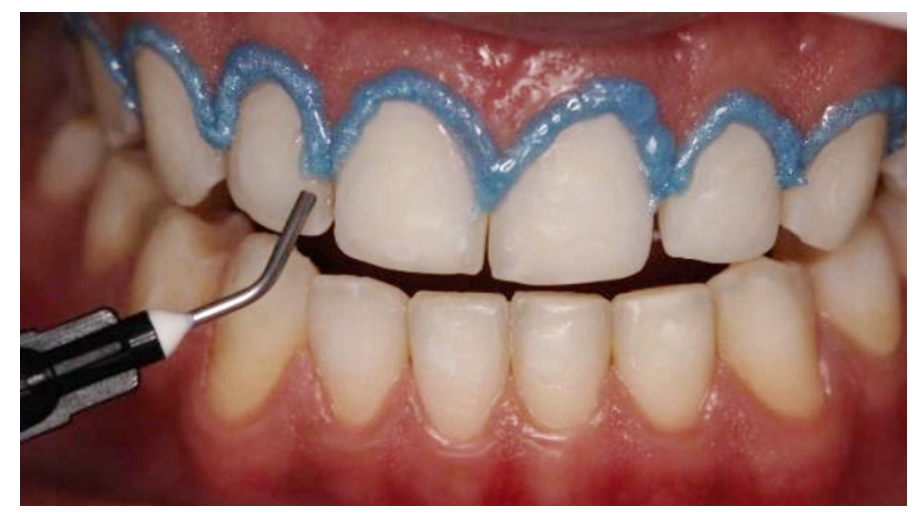

Figura 3: Confecção da barreira gengival Fonte: autores, 2021 
- Examinar com um espelho bucal se existe algum espaço vazio entre a gengiva marginal e a superfície dos dentes;

- Aplicação de dessensibilizante à base de nitrato de potássio a $5 \% \mathrm{e}$ fluoreto de sódio a 2\% (Dessensibilize KF 2\%) durante 10 minutos;

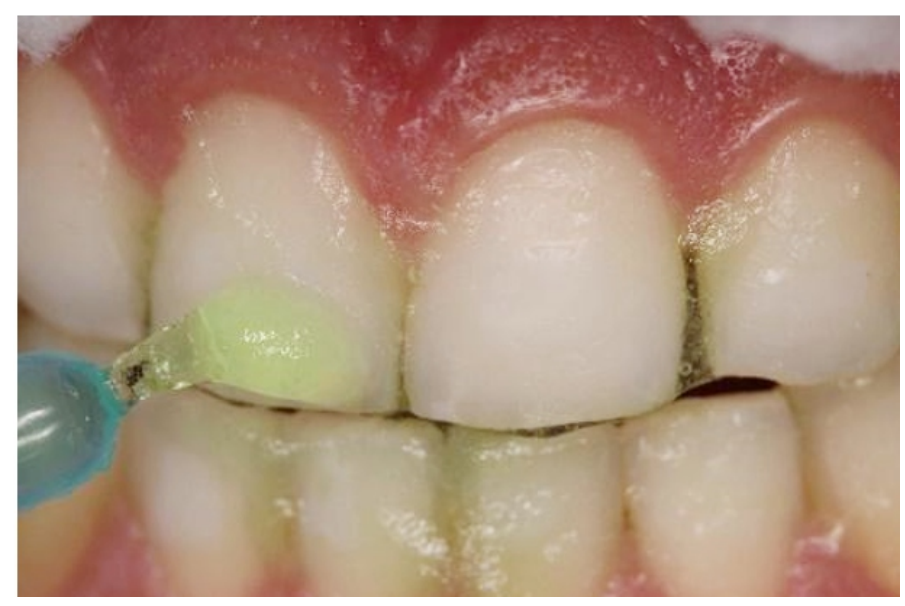

Figura 4: Aplicação de dessensibilizante Fonte: autores, 2021

- Manipulação do agente clareador: existem uma variedade de géis de formas de apresentação variada, dependendo do fabricante. A proporção peróxido/espessante deverá seguir o que recomenda o fabricante. Depois de manipulado, o gel deve ser aplicado em espessura de $1 \mathrm{~mm}$ sobre a face vestibular dos dentes, inclusive nas proximais, estendendo-se para a incisal;

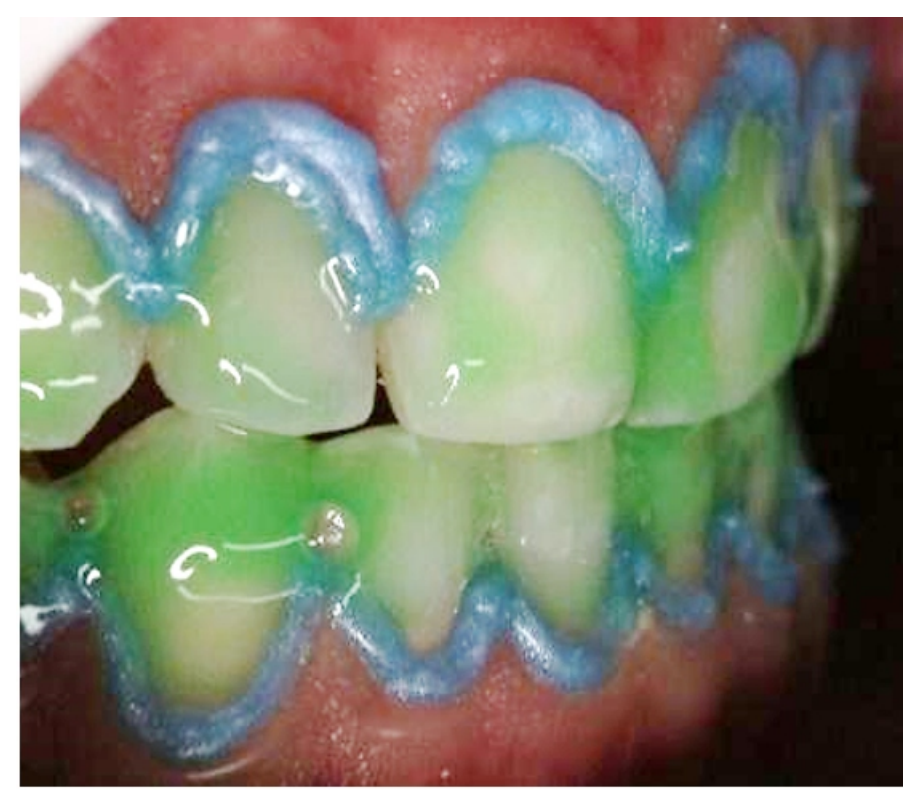

Figura 5: Manipulação do agente clareador Fonte: autores, 2021 
- Tempo de aplicação e troca do agente clareador: esses fatores vão depender da concentração e da marca comercial do agente. Lembrando que caso o fabricante sugira a necessidade de realização de trocas durante a sessão essas deverão ser respeitadas quanto ao tempo e quantidade de vezes;

- Durante a aplicação, o gel deverá ser movimentado 3 a 4 vezes com o auxílio de um microaplicador para melhorar o contato dente/gel clareador;

- Remoção do gel: inicialmente o gel deve ser removido com o auxílio de uma cânula aspiradora e, em seguida, utiliza-se uma gaze que deve ser passada em um único sentido, de cervical para oclusal, para finalizar, deve ser realizada a lavagem com spray ar/água;

- Remoção da barreira gengival com sonda exploradora;

- Aplicação de agente dessensibilizante ou flúor gel neutro por 10 minutos.

\section{Técnica de Clareamento Dental para dentes desvitalizados}

\subsection{Material necessário}

- Equipamentos de proteção individual;

- Pedra-pomes;

- Escala de cor;

- 1 lençol de borracha;

- Álcool absoluto;

- 1 pote pó de hidróxido de cálcio;

- Cimento de ionômero de vidro;

- Perborato de sódio (técnica mediata);

- Peróxido de carbamida 37\% (técnica imediata).

\subsection{Instrumental necessário}

- Kit de exame clínico;

- Material para isolamento absoluto;

- 1 escova de Robinson;

- 1 sonda periodontal milimetrada;

- 1 taça de borracha;

- 1 lamparina a álcool;

- 1 turbina de baixa rotação;

- 1 turbina de alta rotação; 
- Brocas carbide para remoção de tecido cariado;

- Pontas diamantadas esféricas;

- 1 seringa centrix.

\subsection{Passo a passo Clínico}

- Radiografia inicial para avaliação da qualidade do tratamento endodôntico, saúde de tecidos periapicais e analisar se está indicado o clareamento interno;

- Profilaxia dos elementos dentários com pedra-pomes e água associada à escova de Robson ou taça de borracha;

- Registro inicial da cor por meio de escala de cores associadas a fotografias;

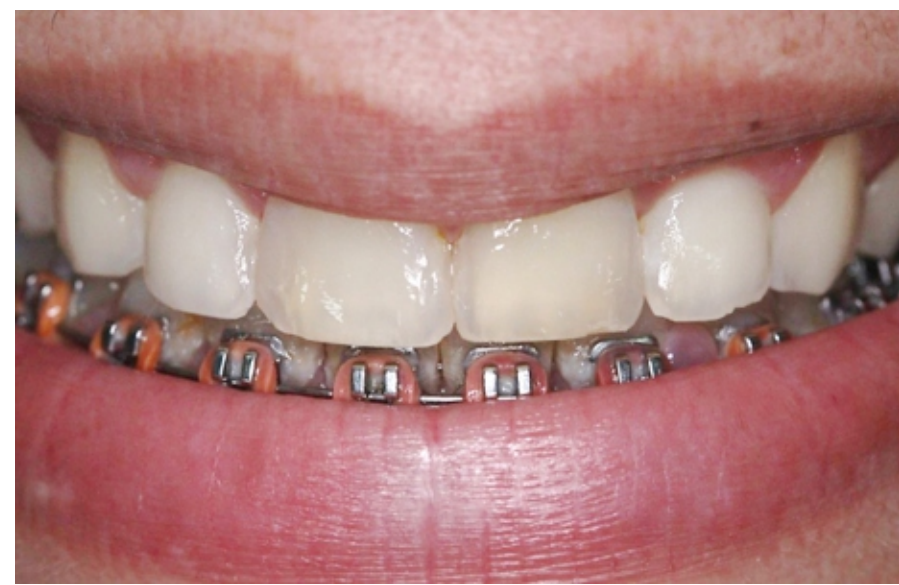

Figura 6: Registro inicial da cor por meio de escala de cores Fonte: autores, 2021

- Registro da altura da coroa clínica com sonda periodontal, com o objetivo de avaliar quanto deverá ser desobstruído para que o agente clareador haja em toda a porção coronária;

- Proteção dos tecidos moles e isolamento absoluto;

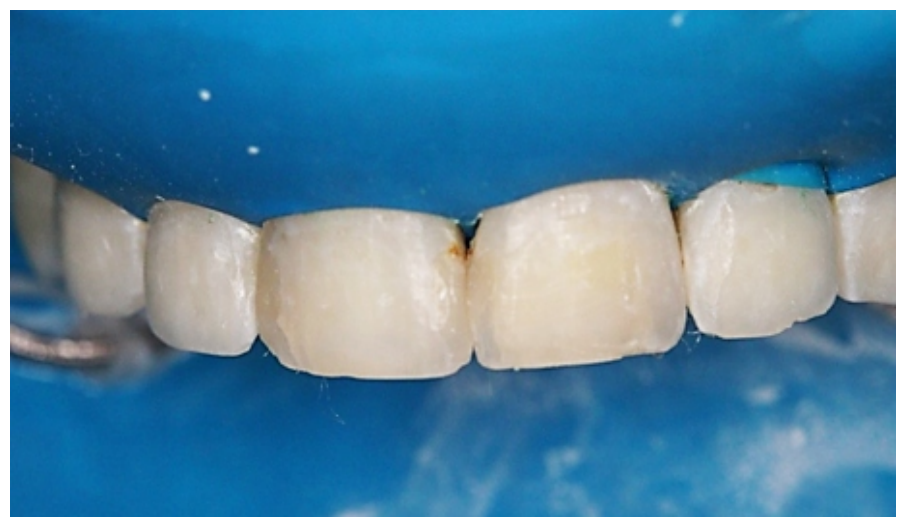

Figura 7:Proteção dos tecidos moles e isolamento absoluto Fonte: autores, 2021 
- Acesso à câmara pulpar. Deve-se remover: áreas retentivas, restos de tecido cariado e material obturador definitivo ou provisório;

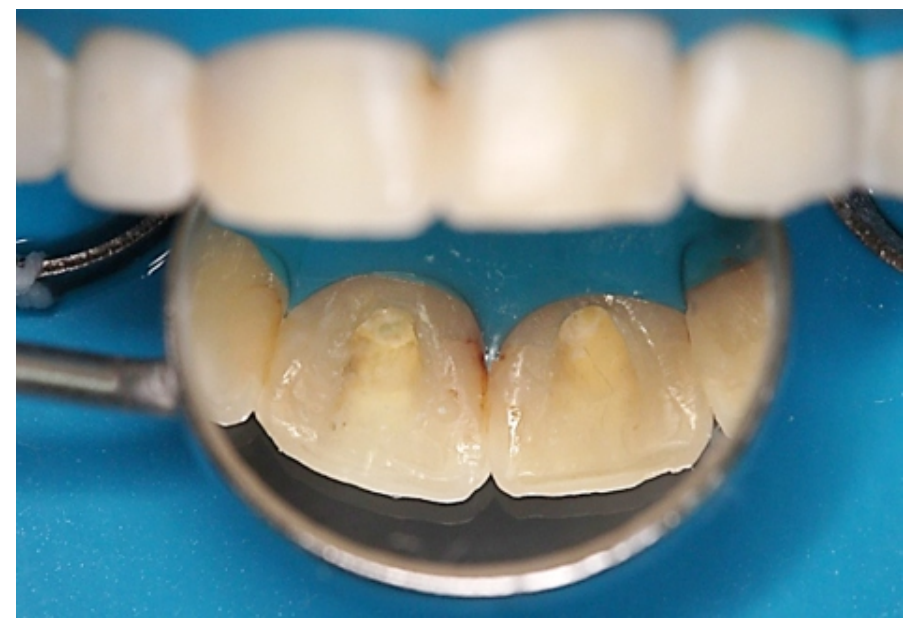

Figura 8: Acesso à câmara pulpar Fonte: autores, 2021

- Acesso ao canal radicular. Deve ser desobturado todo o comprimento da coroa clínica registrado anteriormente e mais 3 $\mathrm{mm}$ referentes ao espaço biológico;

- Confecção do selamento biomecânico: aplica-se inicialmente o pasta de hidróxido de cálcio e, em seguida, aplica-se uma base de cimento de ionômero de vidro ( $2 \mathrm{~mm}$ );

- Aplicação do agente clareador, a depender da técnica escolhida:

- Para o clareamento interno mediato utiliza-se o perborato de sódio manipulado com água destilada, aplicando-o de forma a preencher a cavidade, porém deixando um espaço de $2 \mathrm{~mm}$ para confeç̧ão da restauração provisória com cimento de ionômero de vidro. Deverá haver uma reavaliação de 4 a 7 dias após a primeira sessão, caso seja necessário, pode-se realizar até três trocas. Após o fim do clareamento, deve ser confeccionado um curativo de hidróxido de cálcio e realizar restauração definitiva 7 dias depois.

- Para o clareamento com a técnica imediata faz-se a aplicação em consultório de peróxido de carbamida 37\% (durante 1 hora) ou peróxido de hidrogênio 35\% (durante $45 \mathrm{~min}$ ) por 3 sessões. Realiza-se a restauração definitiva 1 a 2 semanas depois do fim do clareamento, fazendo aplicação de pó ou pasta de hidróxido de cálcio nesse período. 


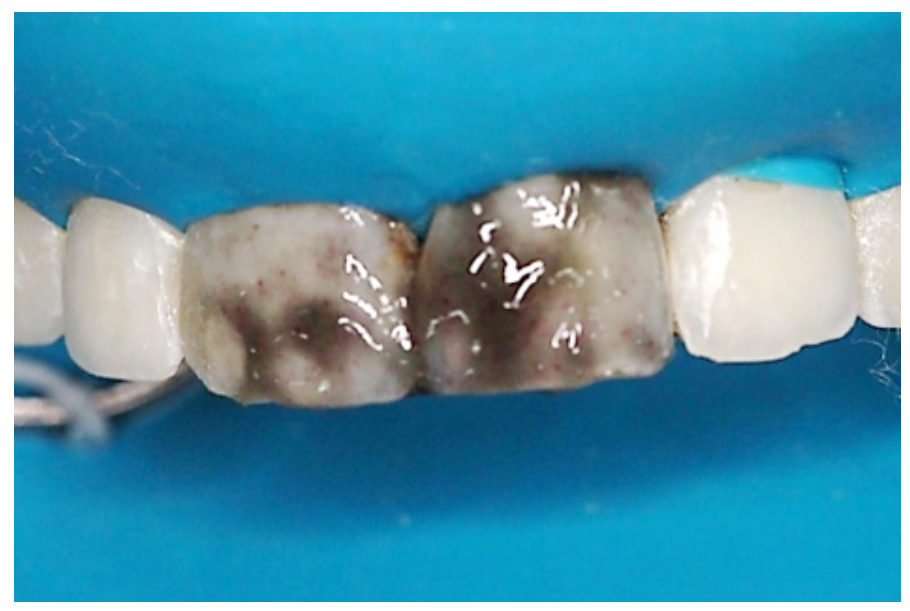

Figura 9: Aplicação do agente clareador Fonte: autores, 2021

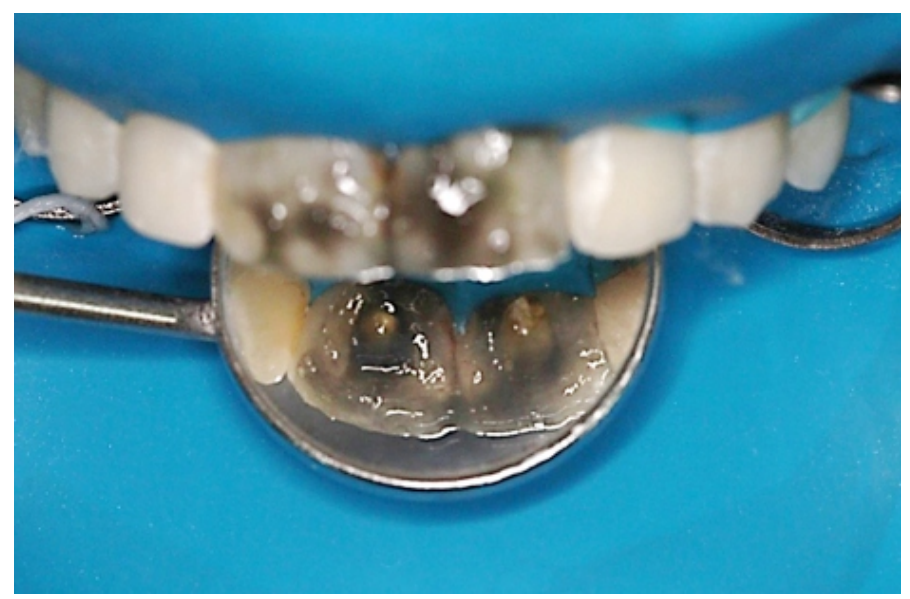

Figura 10: Clareamento com a técnica imediata Fonte: autores, 2021

- Aspecto final.

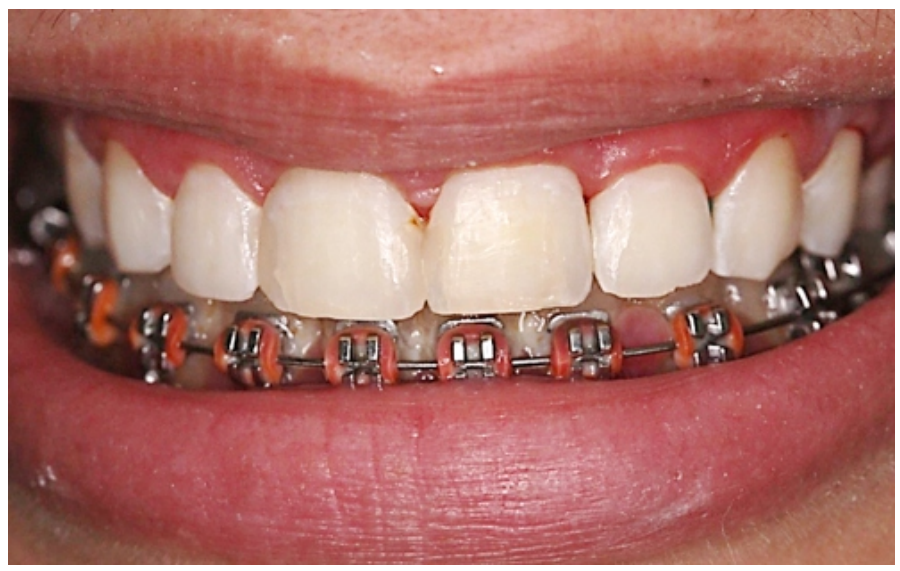

Figura 11: Aspecto final Fonte: autores, 2021 


\section{REFERÊNCIAS}

1. CARVALHO, N. R. et al. Clareamento Caseiro Supervisionado: Revisão Literatura. International Dental Journal, Recife, v. 7, n. 3, p. 178-183, jul./set. 2008.

2. REIS, Alessandra; LOGUERCIO, Alessandro Dourado. Materiais dentários diretos: dos fundamentos à aplicação clínica. Santos, 2007. 


\section{Capitulo8}

\section{HIPERSENSIBILIDADE DENTINÁRIA}

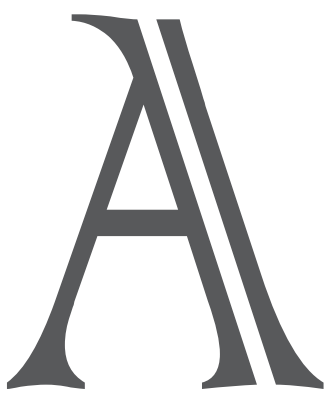

Hipersensibilidade Dentinária (HD) é uma condição clínica dolorosa que acomete uma porcentagem significativa da população mundial, na maioria dos casos acomete pacientes do sexo feminino. Por definição, a HD pode ser caracterizada como uma dor aguda, transitória e exacerbada com um estímulo não nocivo, podendo ser térmico, tátil ou químico.

Observa-se esse tipo de condição associada a Lesões Cervicais não Cariosas (LCNC) com exposição de dentina ao meio bucal, acometendo em ordem de incidência: $68,8 \%$ em pré-molares, seguidos de $12 \%$ em molares, $11,6 \%$ em caninos e 7,4\% em incisivos. Sabe-se ainda que o surgimento de HD está diretamente relacionado aos hábitos de cada paciente, podendo ser agravada pelo estresse emocional dele.

\section{Mecanismos da Hiperestesia Dentinária}

O surgimento dessa condição dolorosa permanece sem uma explicação definida, e existem vários aspectos que tornam ainda mais confusa a elucidação sobre o surgimento de tal condição dentária:

- Apenas 57\% dos dentes com LCNC apresentam HD;

- O grau de dor é muito variável de um indivíduo para o outro;

- A incidência de dor varia entre os grupos dentários sendo os prémolares mais acometidos;

- A dor é recorrente, mas pode desaparecer sem qualquer tratamento

- A dor pode desaparecer com a aplicação de placebos

- Tal condição não tem relação com a idade.

Sendo assim, existem algumas teorias que tentam explicar o surgimento da HD, são elas: 
I. Teoria da Transdução: sugere a presença de um arranjo sináptico entre as terminações nervosas sensoriais.

II. Teoria da Modulação: sugere que há um estímulo irritante que agride os odontoblastos, que liberam substâncias neurotransmissoras, proteínas vasoativas estimuladoras da dor e aminoácidos, modulando a ação das fibras nervosas.

III. Teoria da Vibração: as fibras nervosas $C$ não se ajustam ao estímulo de injúria, exacerbando a sensação dolorosa.

IV. Teoria Hidrodinâmica: defende que a dor ocorre devido o dente ser uma estrutura rígida, contendo fluidos ou material semifluido, que por ventura, se movimentam frente a um estímulo provocando troca de fluidos. Isso irá causar uma estimulação nervosa próximo a camada odontoblástica.

A teoria hidrodinâmica é a mais aceita atualmente, para tanto, deve-se levar em consideração o comprimento e o diâmetro dos túbulos dentinários, o número de túbulos na superfície exposta, a pressão aplicada e a viscosidade do fluido.

\section{Diagnóstico Diferencial de HD}

Para realizar um bom diagnóstico de HD precisa-se conhecer sinais e sintomas que a caracterizam, sendo eles:

- Dor provocada por estímulos térmicos, tácteis e químicos;

- Dor localizada com definição do elemento dentário, bem como a região envolvida;

- Períodos de remissão espontânea;

- Associação com estado de ansiedade.

Logo, o profissional deve realizar um exame clínico minucioso e detalhado, pois existem muitas condições que se assemelham à $\mathrm{HD}$, tais como: trincas de esmalte, fraturas que levam a exposição de dentina, restaurações deficientes, cárie e sensibilidade após realização de procedimento restaurador. Todos os eventos citados acima apresentam os mesmos sintomas, exceto pela dor com a hiperfunção.

\section{Tratamento da HD}

\subsection{Agentes de ação Anti-inflamatória}

Agentes com esse mecanismo de ação pressupõem que tal condição está associada à inflamação pulpar, sendo assim, esses possuem efeito nesse tecido inflamado. Estes agentes são, por exemplo: prednisolona $1 \% \mathrm{com}$ paraclorofenol, m-cresil acetato e cânfora, e parametasona. 


\subsection{Agentes com efeito oclusivo nos canalículos dentinários}

Pode ocorrer por precipitação de proteínas, cristais e sais na superfície dentinária.

\subsubsection{Precipitação de proteínas}

- Nitrato de prata: coagula os prolongamentos dos odontoblastos formando albuminato de prata, que apresenta uma coloração escura.

- Formalina: na concentração de $40 \%$, aplica-se com compressas de algodão, no entanto, pode causar injúrias pulpares.

- Cloreto de zinco: aplicado por um minuto de fricção seguido por brunimento da dentina, formando um precipitado de cor laranja.

- Glutaraldeído (GA): 5\% de GA associado a 35\% de monômero HEMA, que atuará como veículo para o GA em profundidade nos túbulos dentinários, assim o GA interage com a proteína albumina por meio de seu grupamento aldeído, levando a uma coagulação e obliteração tubular.

\subsubsection{Precipitação de cristais}

- Oxalatos: atuam por meio de precipitação de cristais de oxalato, de cálcio ou de potássio, reduzindo significativamente (até 98\%) a permeabilidade dentinária, e consequentemente, a movimentação de fluidos na dentina. No entanto, não é muito resistente aos desafios dos ácidos orais.

- Estrôncio: o cloreto de estrôncio tem reatividade com o cálcio presente na dentina, e além disso, já foi relatada precipitação de proteínas em ação conjunta.

- Vernizes: a base de resina, fluoreto, clorexidina e composições altamente adesivas ao dente, formando uma barreira mecânica.

- Fluoretos: o fluoreto de sódio é um dos mais comumente usados, gera a precipitação de fluoreto de cálcio dentro dos túbulos dentinários, gerando redução da permeabilidade da dentina. No entanto, saem facilmente com desafios mecânicos e ácidos.

\section{Tratamento de HD}

\subsection{Material necessário}

- 1 caixa de microbrush;

- Pedra-pomes;

- Rolo de algodão; 
- Fio retrator 0-00;

- Afastador labial (espandex);

- Sugador descartável;

- 1 agente dessensibilizante de ação neuronal química;

- 2 agentes desenssibilizantes de ação obliteradora.

\subsection{Instrumentos necessários}

- 1 espátula de resina Suprafill ou de inserção de fio retrator;

- 1 escova de Robinson;

- 1 kit clínico.

\subsection{Passo a passo Clínico}

- O dente a ser trabalhado deve estar isolado com isolamento relativo (rolo de algodão, sugador e afastador labial);

- Realização da profilaxia da região com escova de Robinson com pedra pomes e água;

- Lavagem por 30 segundos;

- Secagem do substrato dental com jato de ar e bolinhas de algodão;

- Inserção do fio retrator no sulco gengival com a espátula indicada;
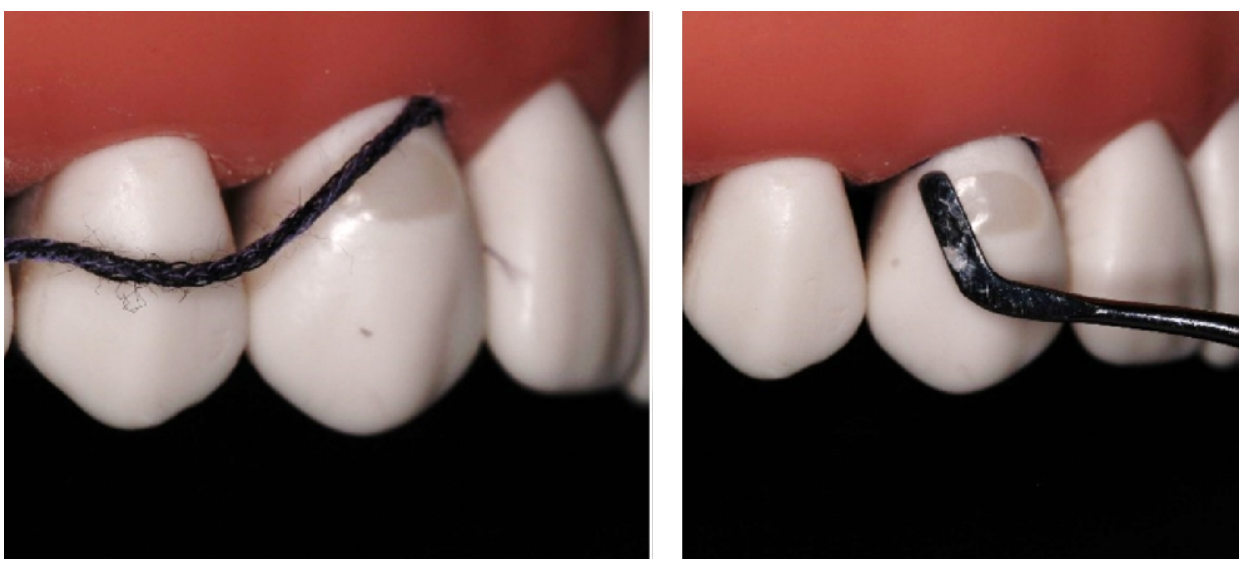

Figura 1: Inserção do fio retrator

Fonte: autores, 2021

- Aplicação do agente dessensibilizante de origem neuronal (ver recomendação do fabricante de tempo de aplicação - em média 5 a 10 minutos); 

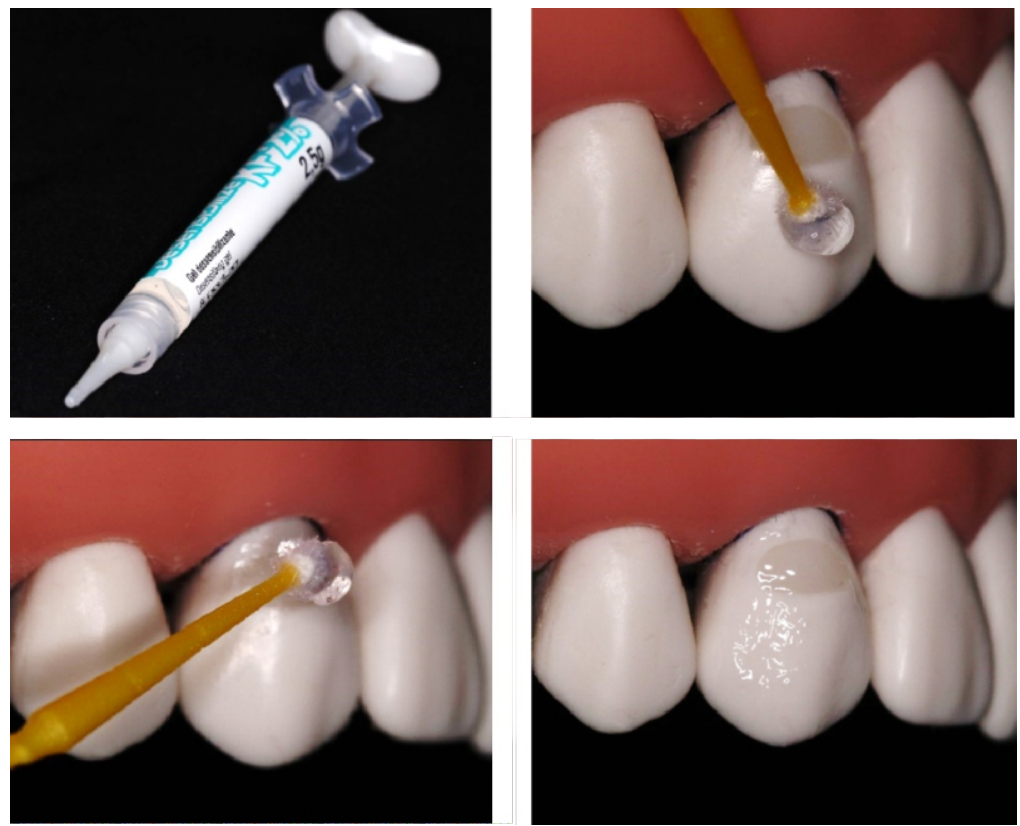

Figura 2: Aplicação do agente dessensibilizante Fonte: autores, 2021

- Remove-se o excesso de material e o fio retrator;

- Inserção do fio retrator no sulco gengival com a espátula indicada;

- Aplicação do agente dessensibilizante de origem neuronal (ver recomendação do fabricante de tempo de aplicação - em média 5 a 10 minutos);

- Espera-se 48 horas;

- Inserção do fio retrator no sulco gengival com a espátula indicada;

- Aplicação do agente dessensibilizante de origem neuronal (ver recomendação do fabricante de tempo de aplicação - em média 5 a 10 minutos) e remove-se o excesso de material e o fio retrator;

- Inserção do fio retrator no sulco gengival com a espátula indicada;
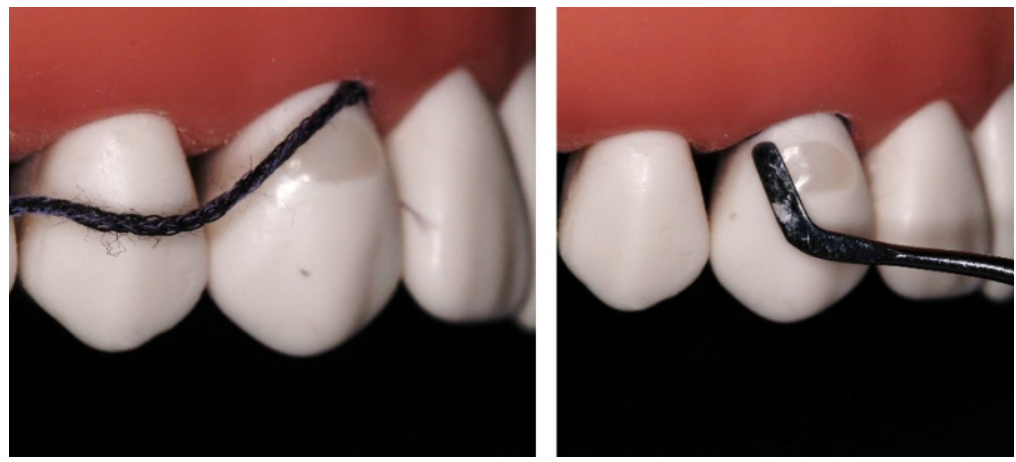

Figura 3: Inserção do fio retrator no sulco gengival com a espátula Fonte: autores, 2021

- Aplicação do agente dessensibilizante de origem neuronal (ver recomendação do fabricante de tempo de aplicação - em média 5 a 10 minutos); 
- Após 48 horas: Inserção do fio retrator no sulco gengival com a espátula indicada;

- Aplicação de um agente obliterador;

- Após 48 horas: Inserção do fio retrator no sulco gengival com a espátula indicada;
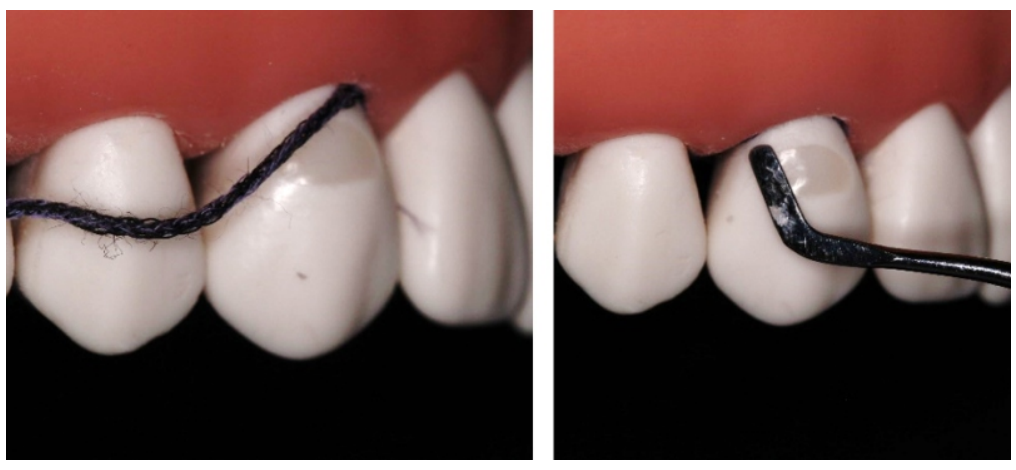

Figura 4: Após 48 h. inserção do fio retrator no sulco gengival com a espátula Fonte: autores, 2021

- Aplicação de um agente obliterador de ação diferente do anterior (ex: oxagel, verniz, flúor).
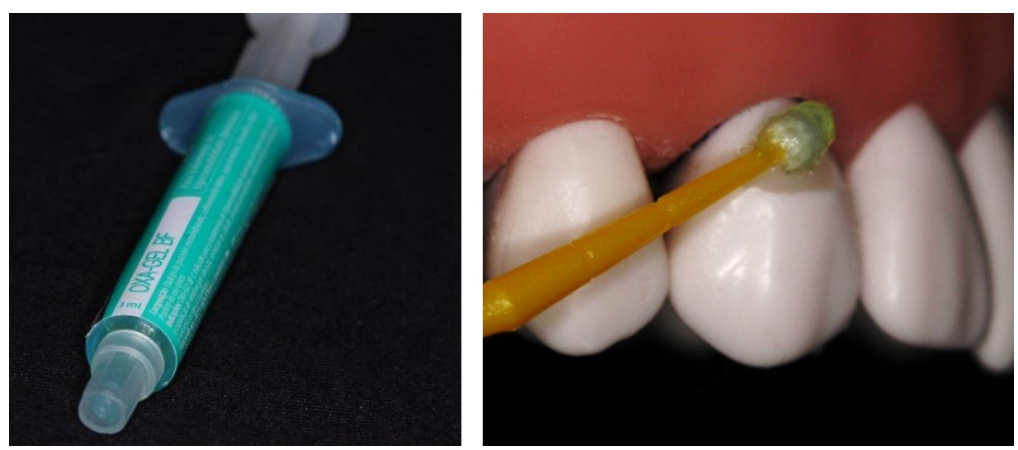

Figura 5: Aplicação de um agente obliterador Fonte: autores, 2021 


\section{REFERÊNCIAS}

1. SOARES, P.V.; GRIPPO J.O. Lesões Cervicais não Cariosas e Hipersensibilidade Dentinária Cervical. 1 ed. Editora Quintessence, 2017.

2. JOSÉ CARLOS PEREIRA. Hiperestesia Dentinária: aspectos clínicos e formas de tratamento. Maxi-Odonto Dentística, Bauru-SP, v. 1, f. 2, março, 1995. 


\title{
Capitulo9
}

\section{RESTAURAÇÕES COM RESINA COMPOSTA EM DENTES ANTERIORES}

\begin{abstract}
tualmente, as pessoas buscam cada vez mais pela estética do sorriso, visando uma aparência dentária harmônica. Por isso, vários fatores devem ser levados em consideração para que se obtenha um sorriso harmônico, natural e bonito, são eles: idade do paciente, tamanho, cor e posição dos dentes e o formato da boca e do rosto, que compõem a estrutura dento-facial ${ }^{1}$.

Com a evolução das formulações, a optimização das propriedades e o desenvolvimento de novas técnicas, as resinas compostas despertam cada vez mais o interesse de profissionais e pacientes para a reabilitação de dentes anteriores, sendo a técnica de restauração direta mais simples, não necessitando de nenhum tipo de preparo, exigindo apenas o condicionamento ácido total do dente. Apresentando, além disso, a vantagem de depender exclusivamente do profissional e consequentemente, o resultado está diretamente ligado à técnica e ao conhecimento do cirurgião dentista 2,3 .
\end{abstract}

\section{Indicações para restaurações anteriores diretas e materiais}

Apesar de ser a técnica mais simples para o recontorno estético de dentes anteriores, nem todos eles possuem indicação para restauração direta em resina composta, no entanto, existem diversas indicações para o tratamento com resina composta: pequenos fechamentos de espaços, problemas isolados, restaurações estéticas, pequenas alterações de forma e de cor, finalização ortodôntica e necessidade de transformação estética generalizada em pacientes jovens com grande presença de estrutura dentária saudável ${ }^{3}$. Assim, as resinas compostas mais indicadas para restaurações em dentes anteriores são as microhíbridas (apresentam boas propriedades mecânicas e polimento razoável) e as nanoparticuladas (boas propriedades mecânicas e boa estética) ${ }^{3}$. 


\section{Estratificação das restaurações}

Como consequência de dificuldades encontradas na restauração de dentes anteriores quanto a escolha incorreta de resinas com características ópticas favoráveis e seu uso em espessura inadequada, a técnica de estratificação é, atualmente, considerada o melhor método de realizar restaurações estéticas em resina composta. A estratificação é a caracterização de um dente mediante a tríade matiz, valor e croma, devendo levar em consideração as propriedades ópticas das resinas compostas: opacidade (descrição de materiais que absorvem luz, não permitindo sua passagem), translucidez (materiais permitem a passagem de luz em seu interior, porém modificando a direção da luz) e transparência (material permite a passagem de luz sem alterar a sua direção). Em relação a espessura do material, ela está diretamente relacionada à variação do índice de refração, quanto mais espesso menor será a translucidez, quanto menos espesso, maior a translucidez, por exemplo: o terço cervical é mais espesso e menos translúcido, havendo menor percepção da dentina, já o terço cervical é menos espesso e mais translúcido, possibilitando maior percepção da dentina ${ }^{3}$.

Dessa forma, a estratificação trabalha com camadas de resina, sendo elas:

- Resina para primeira camada (dentina ou opaca);

- Resina para segunda camada (esmalte cromático);

- Resinas para terceira camada (esmalte acromático);

- Resinas para efeito (effect, transparente).

\section{Restauração Classe III em resina composta}

\subsection{Material necessário}

- Ácido fosfórico 37\%;

- Adesivo dental;

- Resina composta nanoparticulada ou microparticulada para esmalte e dentina;

- Fotopolimerizador;

- Pasta de polimento.

\subsection{Instrumental necessário}

- Kit de espátulas;

- Pontas diamantadas;

- Tiras de lixas abrasivas interproximais; 
- Discos flexíveis de óxidos de alumínio;

- Pontas siliconadas abrasivas;

- Disco de feltro;

- Rolinho de algodão;

\subsection{Passo a passo Clínico}

- Seleção de cor;

- Anestesia e Isolamento absoluto;

- Confecção de bisel na face vestibular (ponta tronco-cônica 1111);

- Técnica adesiva convencional de dois passos (ácido fosfórico $30 \mathrm{seg}$ em esmalte e 15 seg em dentina; lavagem pelo dobro do tempo; secagem com bolinha de algodão; aplicação do adesivo; estimulação da volatização do solvente com um leve jato de ar; fotoativação do adesivo em 20 seg);

- Inserção incremental da resina composta (esmalte; dentina e efeito);

- Acabamento (pontas diamantadas de granulação fina e ultrafina ou as brocas multilaminadas em alta rotação e discos flexíveis de óxido de alumínio - Sof-Lex ou TDV) em ordem decrescente de abrasividade ou utilizar as pontas siliconadas abrasivas;

- Polimento (disco de feltro com pasta diamantada de polimento).

\section{Restauração Classe IV em resina composta}

\subsection{Material necessário}

- Ácido fosfórico 37\%;

- Adesivo dental;

- Resina composta nanoparticulada ou microparticulada para esmalte e dentina;

- Fotopolimerizador;

- Pasta de polimento;

\subsection{Instrumental necessário}

- Kit de espátulas;

- Pontas diamantadas;

- Tiras de lixas abrasivas interproximais;

- Discos flexíveis de óxidos de alumínio;

- Pontas siliconadas abrasivas; 
- Disco de feltro;

- Rolinho de algodão;

\subsection{Passo a passo Clínico}

- Seleção de cor;

- Anestesia e Isolamento absoluto;

- Confecção de bisel na face vestibular (ponta tronco-cônica 1111);
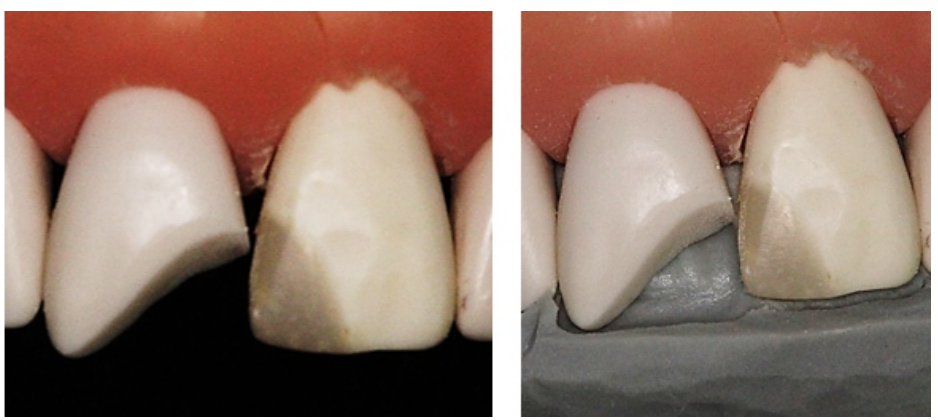

Figura 1: Confecção de bisel

Fonte: autores, 2021

- Técnica adesiva convencional de dois passos (ácido fosfórico $30 \mathrm{seg}$ em esmalte e 15 seg em dentina; lavagem pelo dobro do tempo; secagem com bolinha de algodão; aplicação do adesivo; estimulação da volatilização do solvente com um leve jato de ar; fotoativação do adesivo em 20 seg);
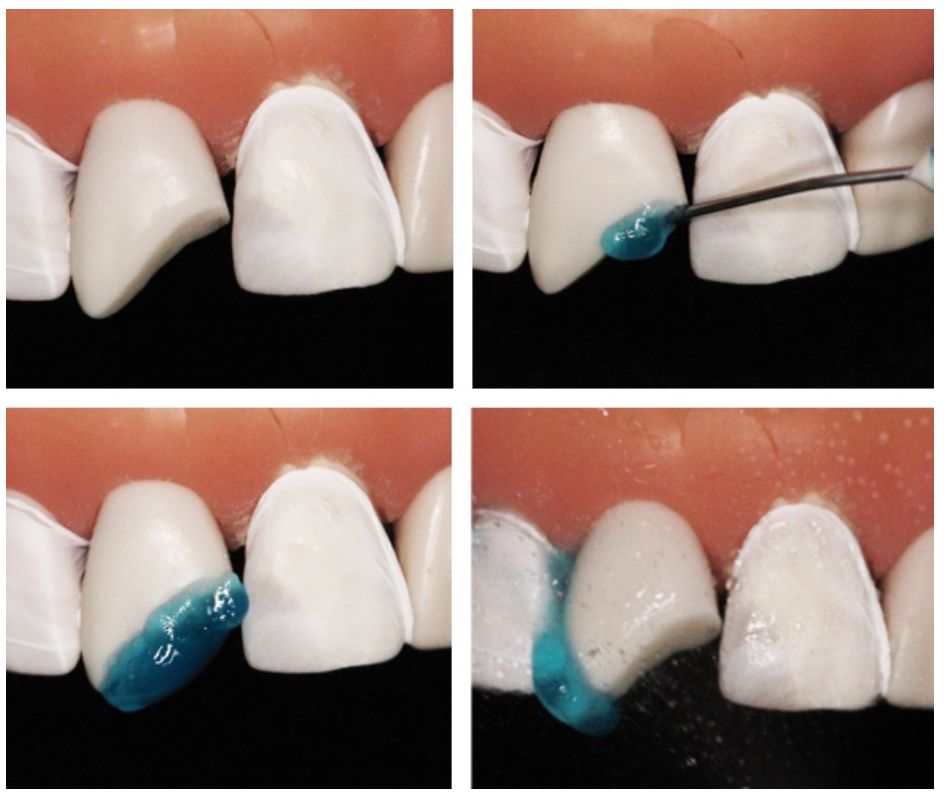

Figura 2: Técnica adesiva convencional de dois passos Fonte: autores, 2021

- Inserção incremental da resina composta (esmalte; dentina e efeito); 

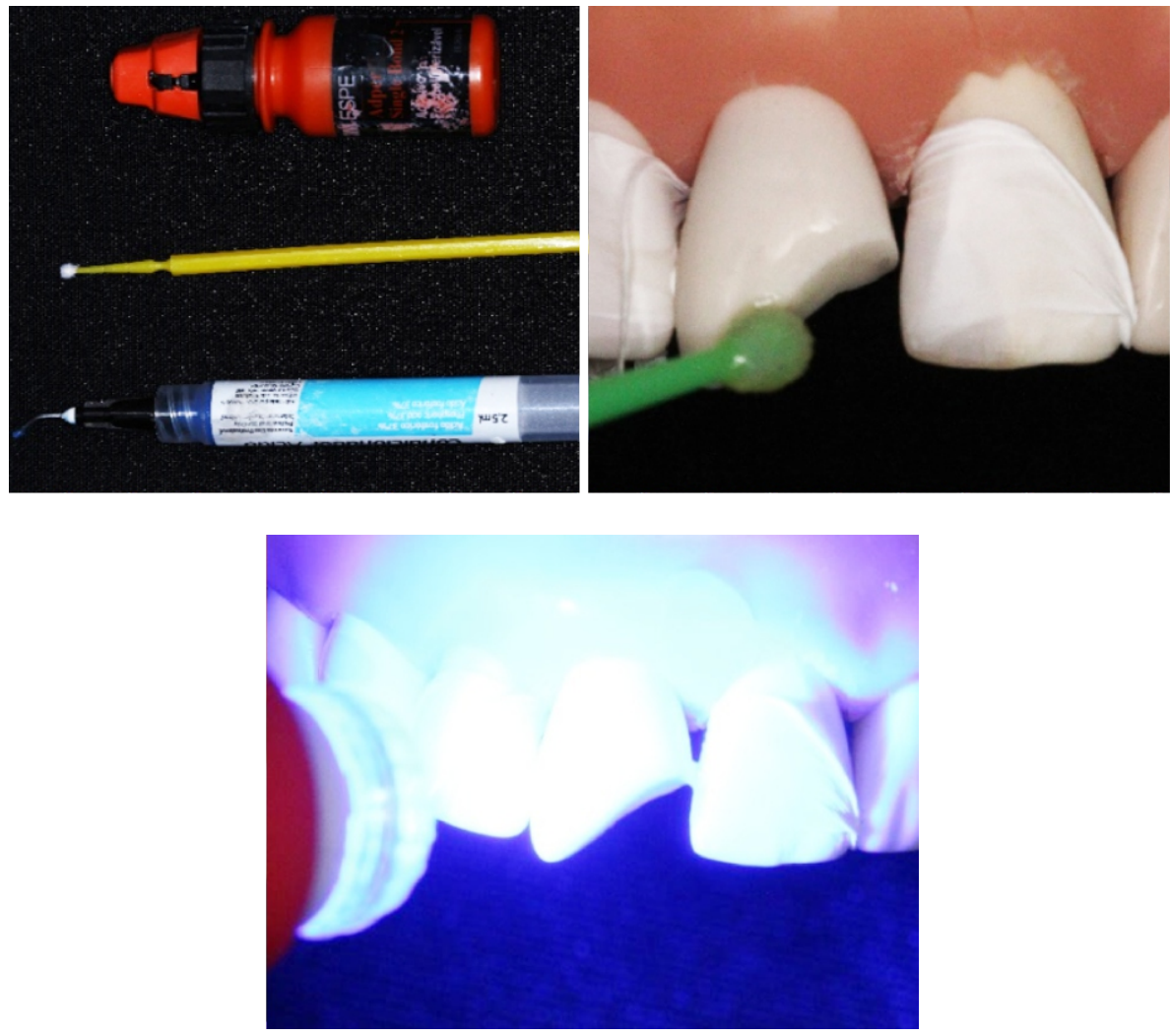

Figura 3: Fotoativação do adesivo Fonte: autores, 2021

- Acabamento (pontas diamantadas de granulação fina e ultrafina ou as brocas multilaminadas em alta rotação e discos flexíveis de óxido de alumínio (Sof-Lex ou TDV) em ordem decrescente de abrasividade ou utilizar as pontas siliconadas abrasivas;
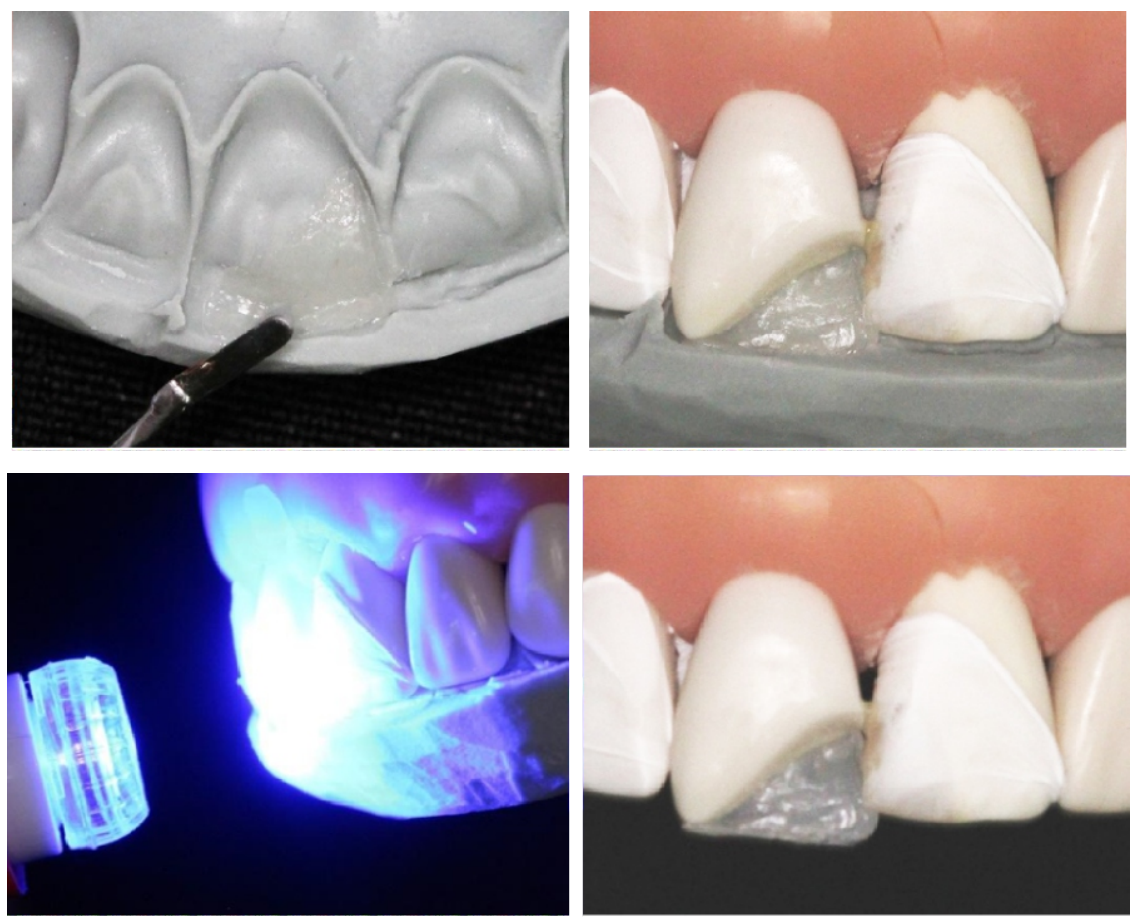

Figura 4: Inserção incremental da resina composta Fonte: autores, 2021 

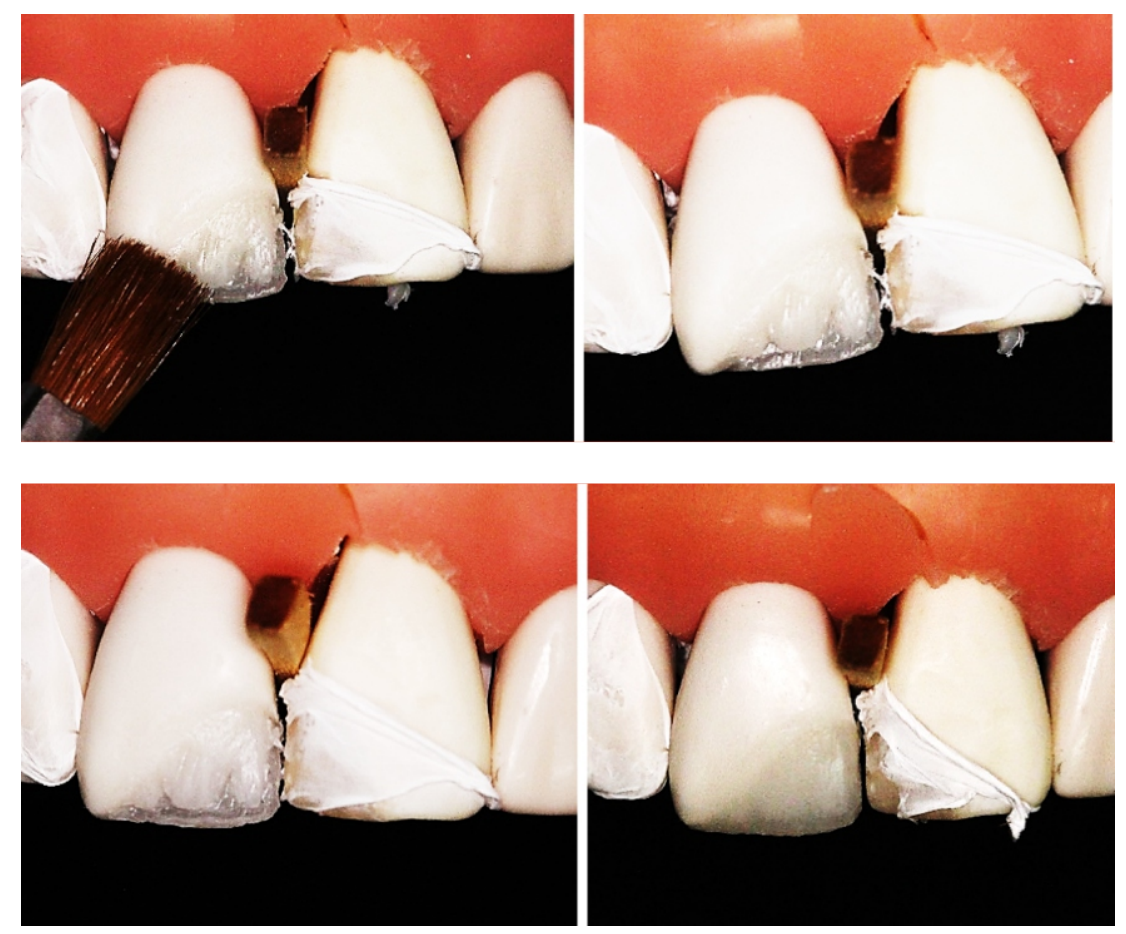

Figura 5: Acabamento em ordem decrescente de abrasividade Fonte: autores, 2021

- Polimento (disco de feltro com pasta diamantada de polimento).

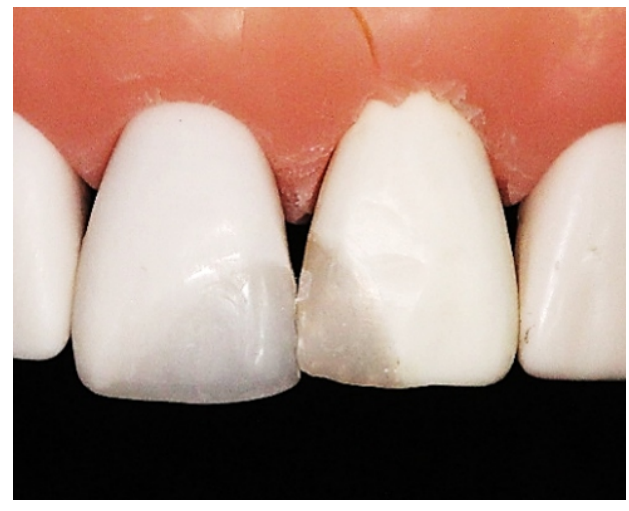

Figura 6: Acabamento em ordem decrescente de abrasividade Fonte: autores, 2021

\section{Restauração Classe V em resina composta}

\subsection{Material necessário}

- Ácido fosfórico 37\%;

- Adesivo dental;

- Resina composta nanoparticulada ou microparticulada para esmalte e dentina;

- Fotopolimerizador;

- Pasta de polimento; 


\subsection{Instrumental necessário}

- Kit de espátulas;

- Pontas diamantadas;

- Discos flexíveis de óxidos de alumínio;

- Pontas siliconadas abrasivas;

- Disco de feltro;

- Rolinho de algodão;

\subsection{Passo a passo Clínico}

- Seleção de cor;

- Anestesia e Isolamento absoluto;

- Confecção de bisel na parede incisal/oclusal (ponta tronco-cônica 1111);

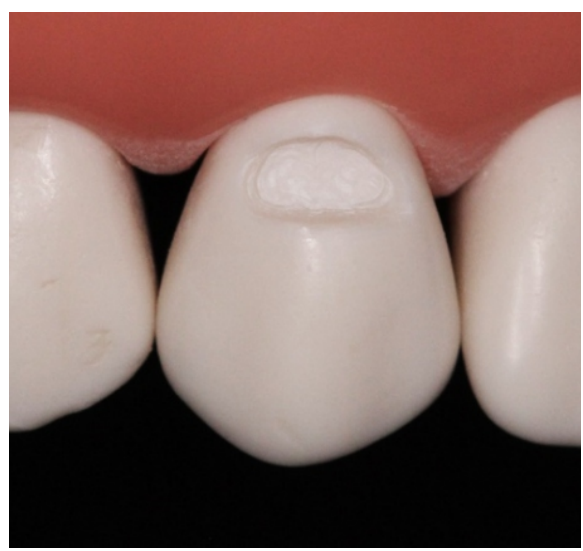

Figura 7: Confecção de bisel na parede incisal/oclusal Fonte: autores, 2021

- Técnica adesiva convencional de dois passos (ácido fosfórico $30 \mathrm{seg}$ em esmalte e 15 seg em dentina; lavagem pelo dobro do tempo; secagem com bolinha de algodão; aplicação do adesivo; estimulação da volatilização do solvente com um leve jato de ar; fotoativação do adesivo em 20 seg);
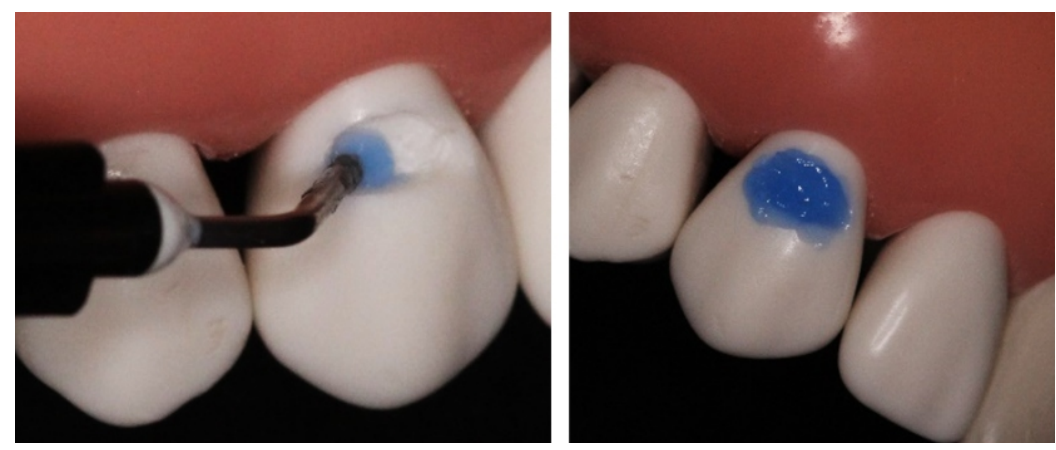

Figura 8: Técnica adesiva convencional de dois passos Fonte: autores, 2021 

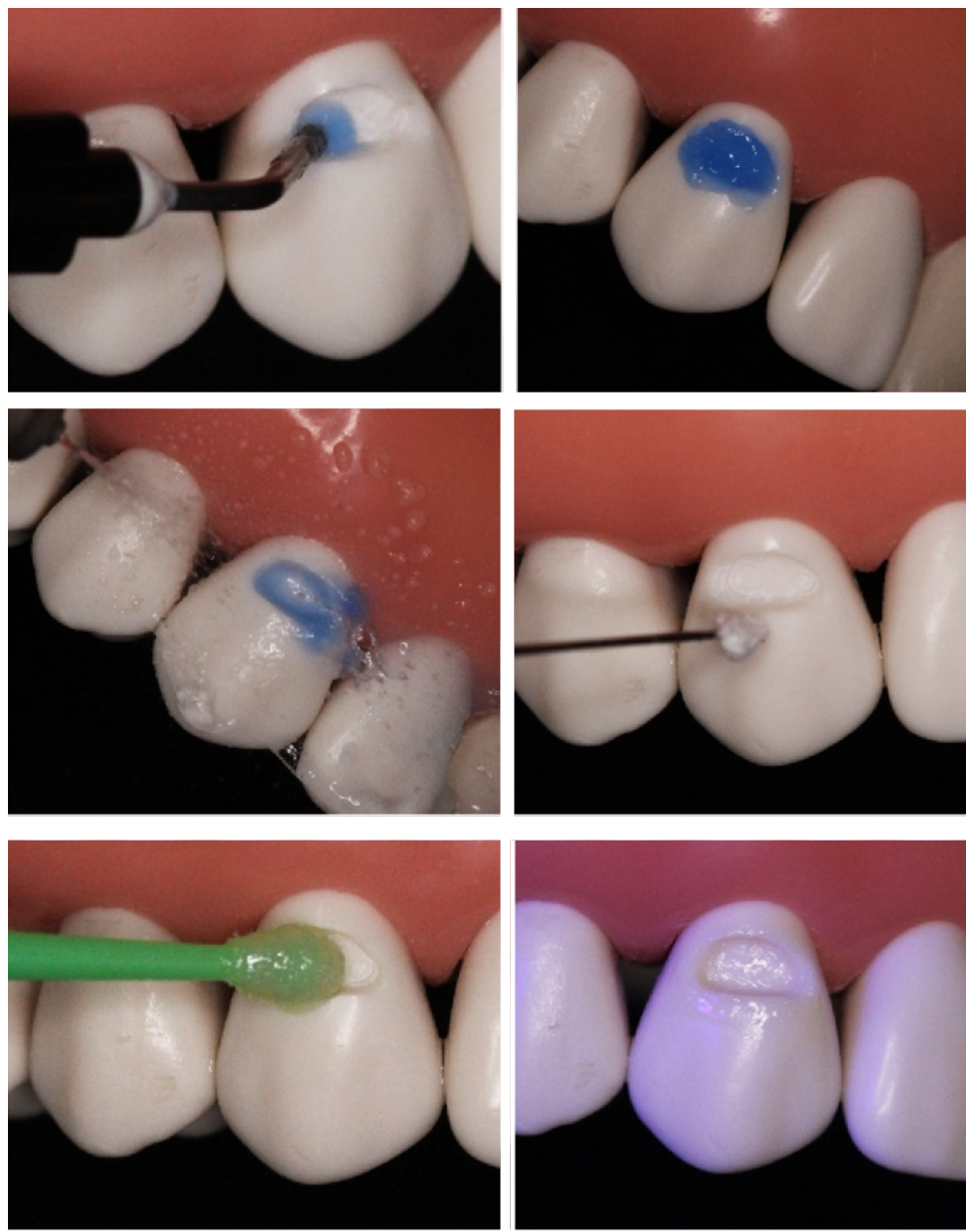

Figura 10: Técnica adesiva convencional de dois passos - Continuação Fonte: autores, 2021

- Inserção incremental da resina composta (esmalte; dentina e efeito);
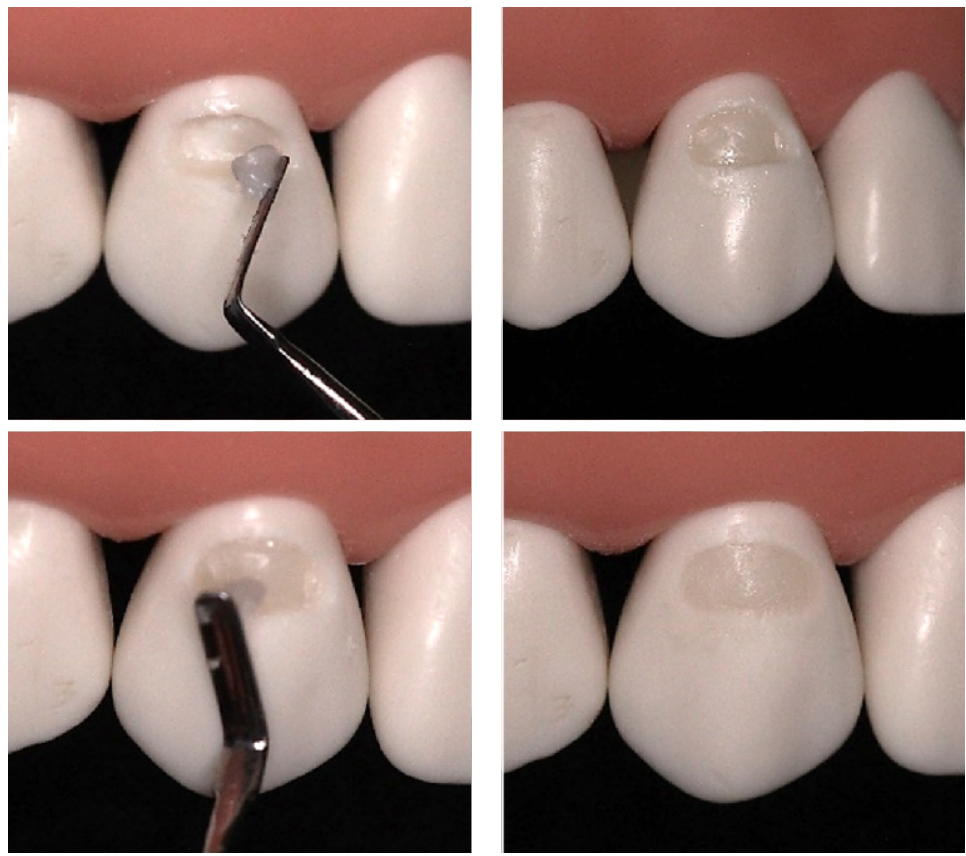

Figura 11: Inserção incremental da resina composta Fonte: autores, 2021 
- Acabamento (pontas diamantadas de granulação fina e ultrafina ou as brocas multilaminadas em alta rotação e discos flexíveis de óxido de alumínio (Sof-Lex ou TDV) em ordem decrescente de abrasividade ou utilizar as pontas siliconadas abrasivas;
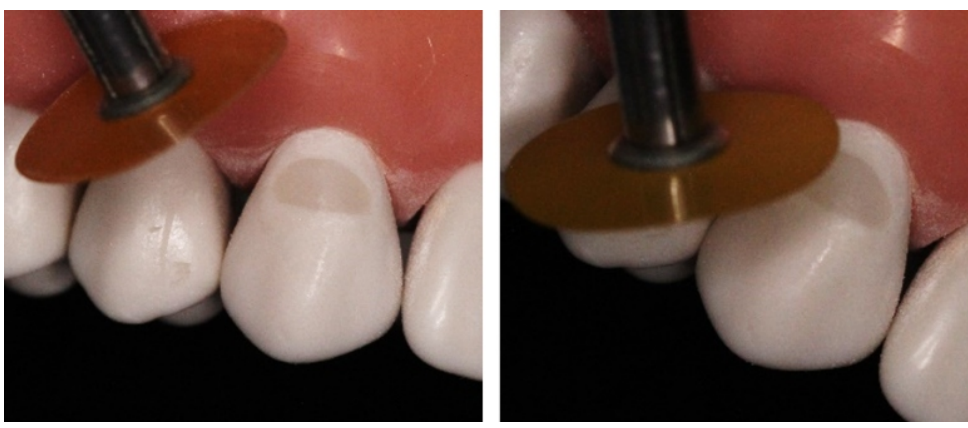

Figura 12: Acabamento em ordem decrescente de abrasividade Fonte: autores, 2021

- Polimento (disco de feltro com pasta diamantada de polimento).
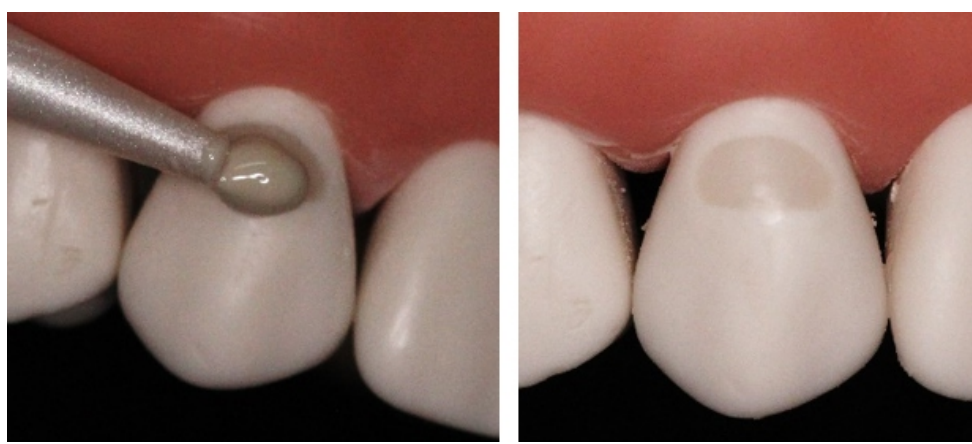

Figura 13: Polimento

Fonte: autores, 2021

\section{Faceta direta em resina composta}

\subsection{Material necessário}

- Ácido fosfórico 37\%;

- Adesivo dental;

- Resina composta nanoparticulada ou microparticulada para esmalte e dentina e resina translúcida;

- Fotopolimerizador;

- Pasta de polimento.

\subsection{Instrumental necessário}

- Kit de espátulas;

- Pontas diamantadas;

- Discos flexíveis de óxidos de alumínio; 
- Pontas siliconadas abrasivas;

- Disco de feltro;

- Rolinho de algodão.

\subsection{Passo a passo clínico}

- Seleção de cor e mapeamento cromático;

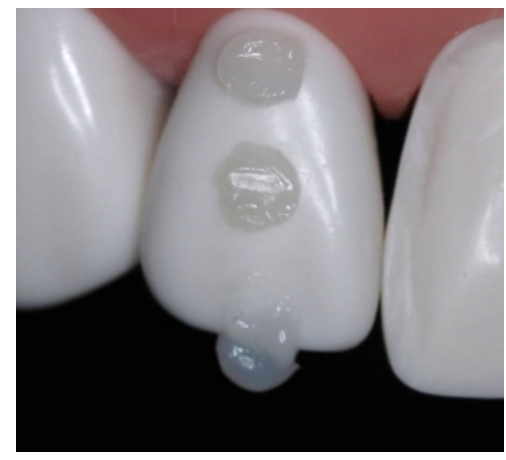

Figura 14: Seleção de cor Fonte: autores, 2021

- Anestesia local e isolamento absoluto;

- Preparo para faceta direta finalizado;

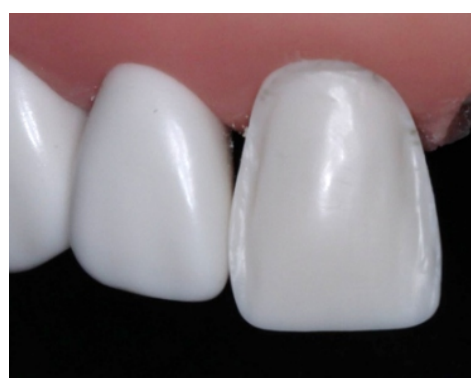

Figura 15: Preparo para faceta direta Fonte: autores, 2021

- Técnica adesiva convencional de dois passos (ácido fosfórico 30 segundos em esmalte e 15 segundos em dentina; lavagem pelo dobro do tempo; secagem com bolinha de algodão; aplicação do adesivo; estimulação da volatização do solvente com um leve jato de ar; fotoativação do adesivo em 20 segundos);
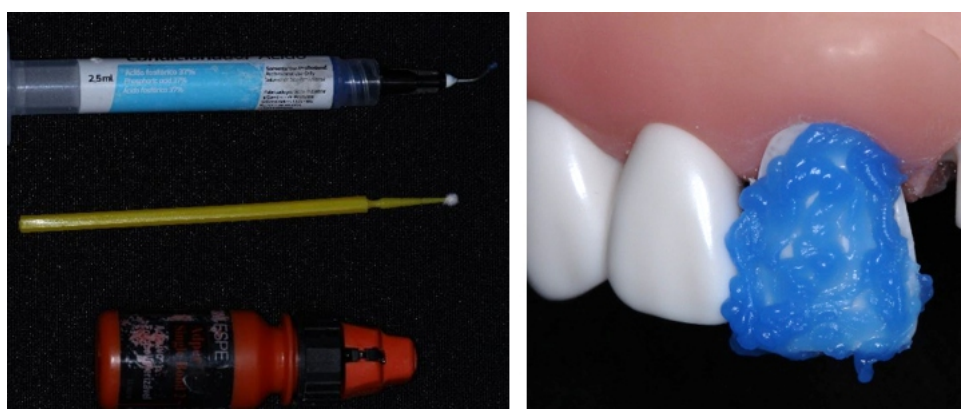

Figura 16: Técnica adesiva convencional de dois passos Fonte: autores, 2021 
- Incremento inicial de resina de dentina obedecendo as inclinações em todos os terços da face vestibular do dente em tratamento;
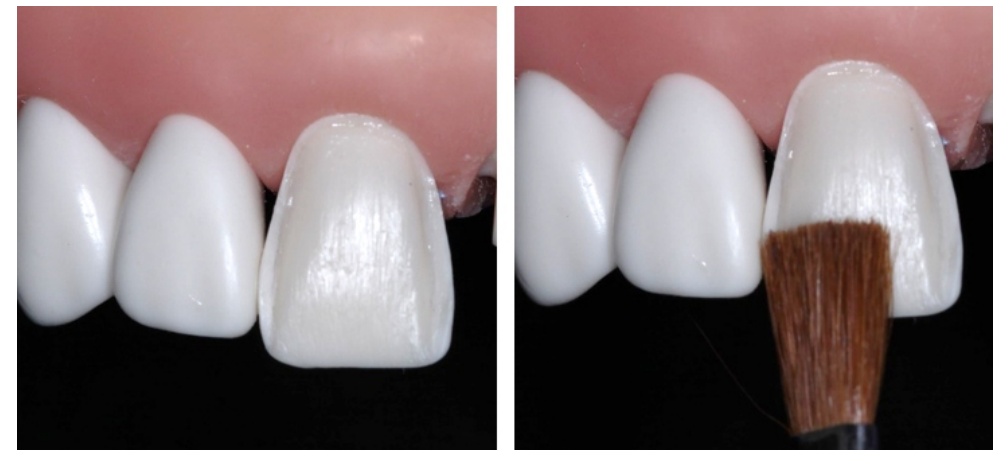

Figura 17: Incremento inicial de resina Fonte: autores, 2021

- Em seguida, deve-se confeccionar os mamelões na borda incisal (a depender das características dos dentes adjacentes do paciente) e logo após fotopolimeriza-se este incremento de resina;
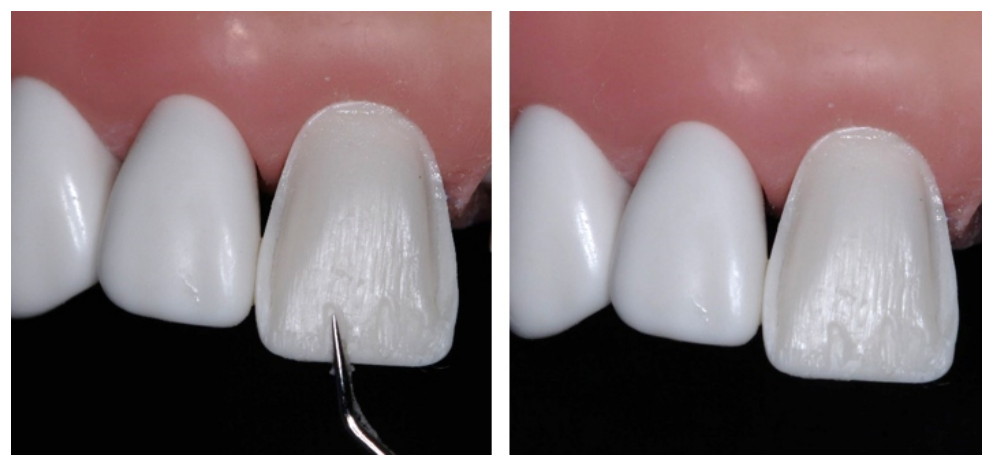

Figura 18: Confeccionar os mamelões Fonte: autores, 2021

- Inserção de um incremento de resina translúcida na borda incisal, para conferir um efeito de translucidez e consequente naturalidade à restauração e em seguida faz-se a fotopolimerização;

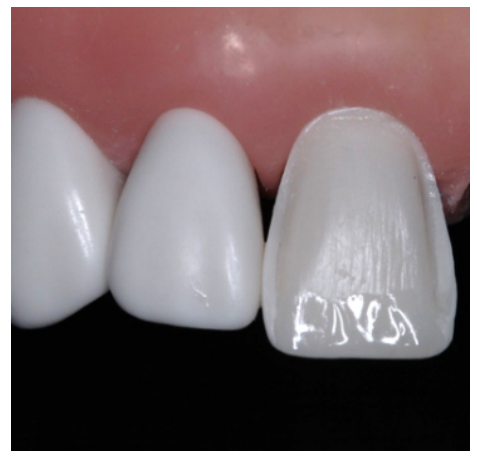

Figura 19: Inserção de um incremento de resina translúcida Fonte: autores, 2021 
- Inserção da camada de resina de esmalte em toda a extensão do preparo realizado e fotopolimerização final;

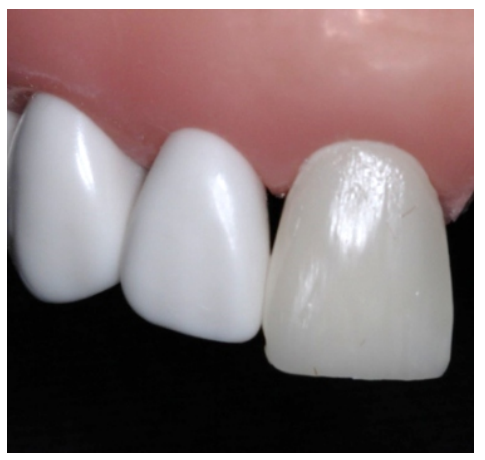

Figura 20: Inserção da camada de resina de esmalte Fonte: autores, 2021

- Acabamento com discos flexíveis de óxido de alumínio;
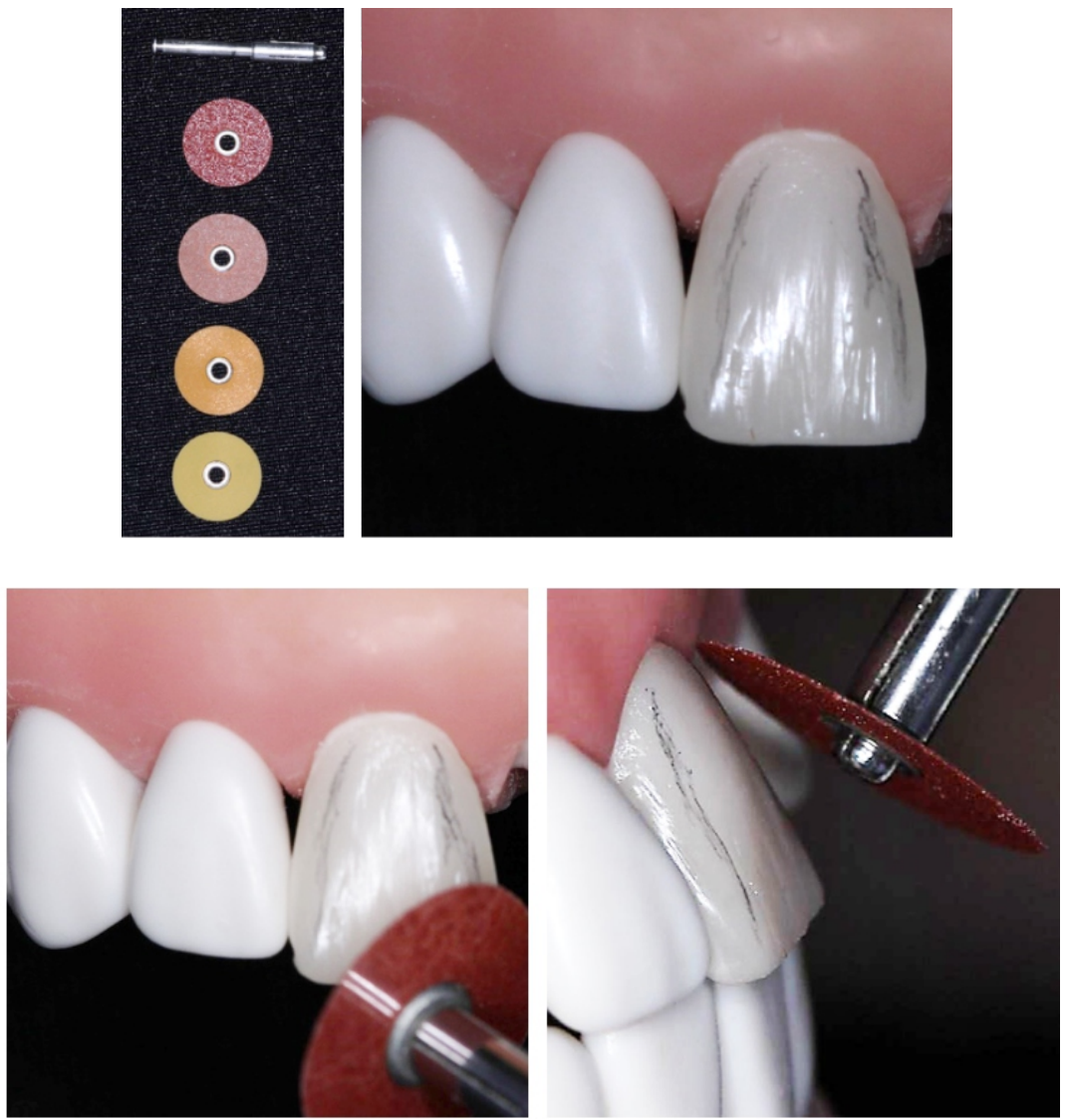

Figura 21: Acabamento com discos flexíveis Fonte: autores, 2021

- Confecção dos sulcos de desenvolvimento com brocas multilaminadas de acabamento para resina composta e polimento com borrachas de acabamento e polimento; 

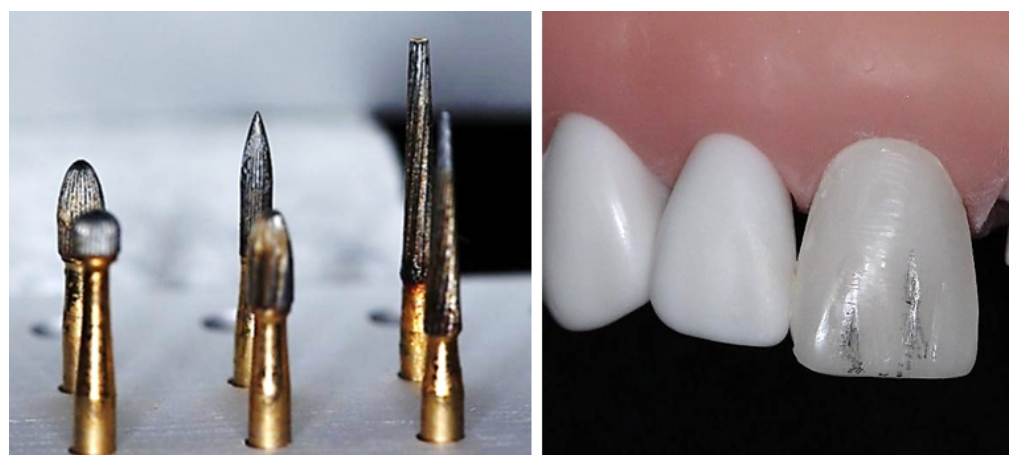

Figura 22: Sulcos de desenvolvimento e brocas multilaminadas Fonte: autores, 2021

- Polimento final da restauração com pasta para polimento e discos de feltro;
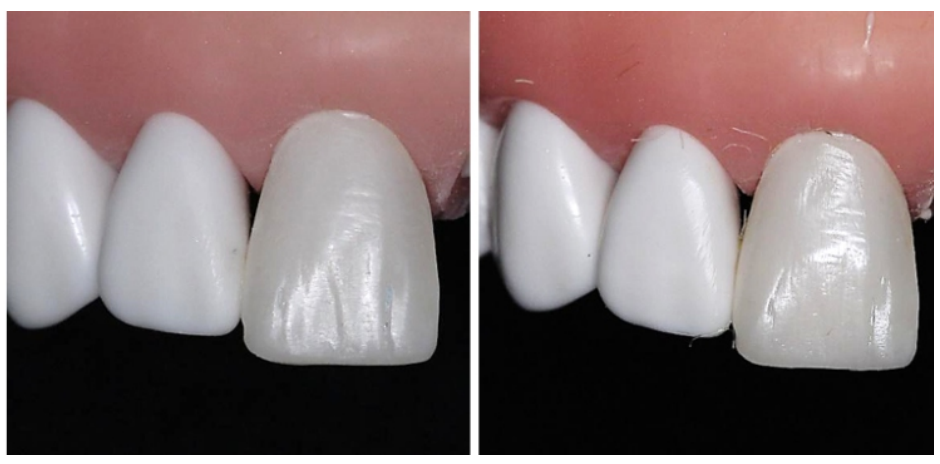

Figura 23: Polimento final da restauração Fonte: autores, 2021

- Aspecto final.
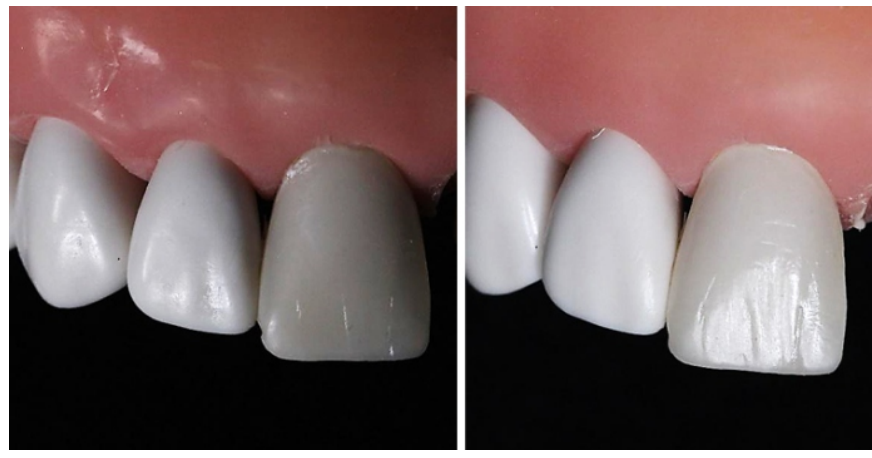

Figura 24: Aspecto final Fonte: autores, 2021 


\section{REFERÊNCIAS}

1. MONDELLI, José. Estética e cosmética em clínica integrada restauradora. Anais, 2004.

2. CORREIA, André; OLIVEIRA, Manuel António; SILVA, Mário Jorge. Conceitos de estratificação nas restaurações de dentes anteriores com resinas compostas. Rev Portug Estomatol, v. 46, n. 3, p. 171-8, 2005.

3. HIRATA, Ronaldo, Shortcuts In Esthetic Dentistry. 1st ed. São Paulo: Quintessence Editora, 2016. 


\section{Capitulo10}

\section{RESTAURAÇÕES COM RESINA COMPOSTA EM DENTES POSTERIORES}

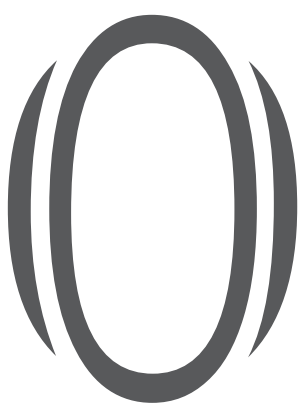

desenvolvimento exponencial da odontologia adesiva, junto com os compósitos, tem possibilitado cada vez mais o uso de resinas compostas como materiais restauradores diretos de cavidades em dentes posteriores de uma forma suficientemente segura e eficaz. No entanto, para que esta prática seja segura e duradoura, deve ser indicada de forma correta, bem como deve-se respeitar todos os seus passos, objetivando evitar insucessos no futuro, como a cárie secundária e a fratura da restauração, as causas mais comuns de insucessos em restaurações de dentes posteriores ${ }^{1}$.

\section{Indicações para restaurações posteriores diretas e as resinas utilizadas}

Nem todo dente posterior possui indicação de restauração direta, somente em alguns casos deve-se lançar mão de resinas compostas para restabelecer estrutura dental perdida, sendo as indicações para restaurações diretas de dentes posteriores: cavidades com caixas proximais reduzidas, términos cervicais visíveis, cavidades sem perda de cúspides e restaurações prévias de amálgama em dente susceptível à fratura. Nesta última indicação, o cirurgião dentista deve ficar atento para realizar uma previsibilidade de possíveis fraturas, indicando corretamente essa substituição ${ }^{2}$.

Assim como nem todos os dentes posteriores são indicados para restaurações diretas em resina composta, nem todo tipo de resina é indicado para utilização em região posterior, tendo em vista que esta área está susceptível a cargas oclusais grandes, sendo assim, as resinas com maior resistência compressiva e maior quantidade de carga, como as nanoparticuladas (tamanho de partícula manométrico) e as microhíbridas (predominância de partículas de cargas menores em torno de 0,4-0,6 $\mu \mathrm{m}$ ), são as mais indicadas para tal procedimento, 
ademais deve-se levar em consideração a característica de manipulação da mesma, esta deve ser mais fácil de se esculpir e mais viscosa. Além da manutenção da resistência mecânica nestas resinas, vale salientar que elas apresentam boas propriedades de polimento, fator primordial para o sucesso da restauração ${ }^{3}$.

\section{Contração de polimerização e o seu controle}

Apesar de serem cada vez mais utilizadas, as resinas compostas ainda possuem características indesejáveis que podem prejudicar o seu desempenho clínico. Dentre estas, a contração de polimerização destaca-se por estar diretamente relacionada à adaptação e ao selamento marginal, por isso, procedimentos clínicos devem ser realizados para que haja o controle da contração de polimerização e os resultados sejam satisfatórios ${ }^{1}$.

Por isso, cavidades classe I ou II, encontradas em dentes posteriores, devem ter uma demanda de atenção especial, pois pode ocorrer a contração de polimerização, gerando estresse na superfície dentária, o que pode levar a diversos problemas pós operatórios, como aumento da sensibilidade, trincas nos dentes, gaps, cáries secundárias, dentre outras características.

\subsection{Técnica de inserção incremental}

Como maneira de controlar os efeitos da contração de polimerização deve-se aperfeiçoar a técnica clínica, realizando o controle do Fator $C$ (razão entre a área de superfícies aderidas e a área de superfícies livres) por meio da técnica de inserção incremental e modulação da fotopolimerização ${ }^{3}$.

A técnica de inserção incremental sugere o uso de pequenos incrementos de resina composta, em torno de $2 \mathrm{~mm}$, polimerizados individualmente para reduzir o fator $\mathrm{C}$. Esta técnica justifica-se pelo fato de que a união de cada incremento restringe-se a poucas paredes, proporcionando mais áreas de superfícies livres para o escoamento e alívio das tensões, havendo menor quantidade de material para sofrer contração ${ }^{2}$.

\section{Passo a passo para restauração classe l em resina composta}

\subsection{Material necessário}

- Ácido fosfórico 37\%;

- Adesivo dental;

- Resina composta nanoparticulada para esmalte e dentina; 
- Fotopolimerizador;

- Pasta de polimento;

- Papel carbono.

\subsection{Instrumentos necessários}

- Kit clínico;

- Turbina de alta rotação;

- Micromotor;

- Contra-ângulo;

- Kit de espátulas;

- Pontas diamantadas;

- Tiras de lixas abrasivas interproximais;

- Discos flexíveis de óxidos de alumínio;

- Pontas siliconadas abrasivas;

- Disco de feltro;

- Rolinho de algodão.

\subsection{Passo a passo Clínico}

- Seleção de cor;

- Anestesia e isolamento absoluto;

- Acesso a lesão com ponta esférica diamantada 1012, 1014 ou 1016 (se necessário);

- Remoção do tecido cariado com broca esférica carbide multilaminada 2, 4, 6, 8 e 10 e/ou colher de dentina (o preparo deve se limitar à remoção de tecido);

- Técnica adesiva convencional de dois passos (ácido fosfórico $30 \mathrm{seg}$ em esmalte e 15 seg em dentina; lavagem pelo dobro do tempo; secagem com bolinha de algodão; aplicação do adesivo; estimulação da volatização do solvente com um leve jato de ar; fotoativação do adesivo em 20 seg);

- Inserção incremental e fotoativação em cada incremento;
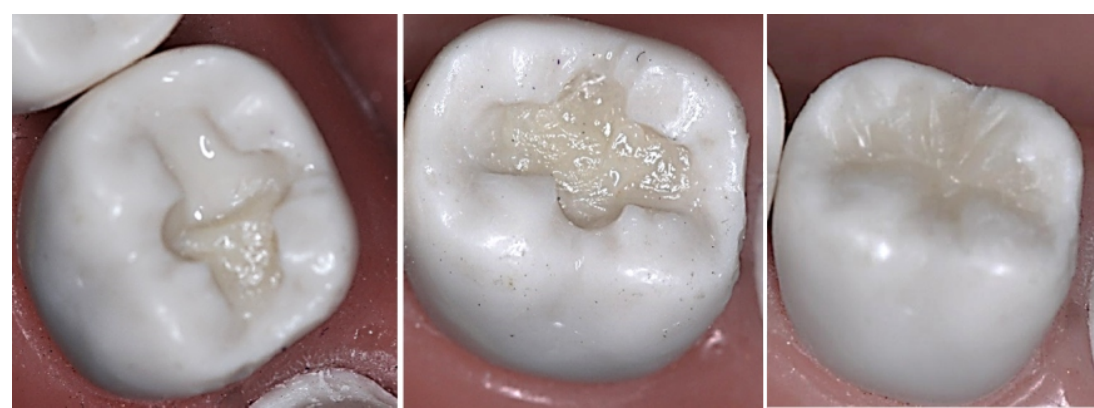

Figura 1: Remoção do tecido cariado com broca esférica Fonte: autores, 2021 
- Ajuste oclusal;

- Acabamento (pontas diamantadas de granulação fina e ultrafina ou as brocas multilaminadas em alta rotação; discos flexíveis de óxido de alumínio (Sof-Lex ou TDV) em ordem decrescente de abrasividade ou utilizar as pontas siliconadas abrasivas);

- Polimento (disco de feltro com pasta diamantada de polimento).

\section{Restauração classe Il em resina composta}

\subsection{Material necessário}

- Ácido fosfórico 37\%;

- Adesivo dental;

- Resina composta nanoparticulada para esmalte e dentina;

- Fotopolimerizador;

- Pasta de polimento;

- Papel carbono.

\subsection{Instrumental necessário}

- Kit clínico;

- Turbina de alta rotação;

- Micromotor;

- Contra-ângulo;

- Kit de espátulas;

- Pontas diamantadas;

- Tiras de lixas abrasivas interproximais;

- Discos flexíveis de óxidos de alumínio;

- Pontas siliconadas abrasivas;

- Disco de feltro;

- Rolinho de algodão.

\subsection{Passo a passo Clínico}

- Seleção de cor;

- Checagem dos pontos de contato;

- Anestesia e isolamento absoluto;

- Acesso a lesão com ponta esférica diamantada 1012, 1014 ou 1016 (Se necessário); 
- Remoção do tecido cariado com broca esférica carbide multilaminada 2, 4, 6, 8 e 10 e/ou colher de dentina (o preparo deve se limitar à remoção de tecido); deve realizar o acabamento das margens com o recortador de margem gengival e/ou brocas em baixa rotação;

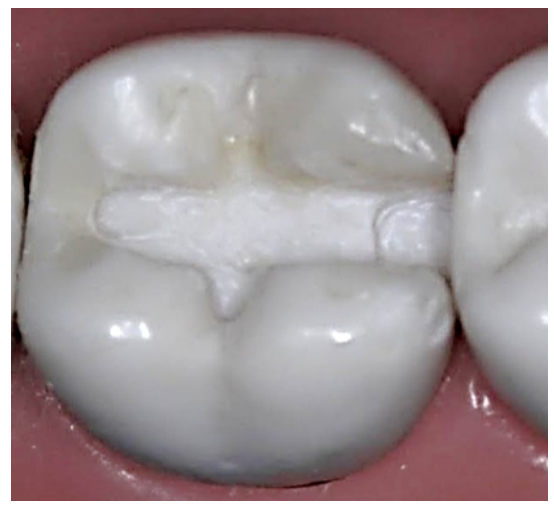

Figura 2: Acesso a lesão com ponta esférica diamantada Fonte: autores, 2021

- Técnica adesiva convencional de dois passos (ácido fosfórico 30 segundos em esmalte e 15 segundos em dentina; lavagem pelo dobro do tempo; secagem com bolinha de algodão; aplicação do adesivo; estimulação da volatilização do solvente com um leve jato de ar; fotoativação do adesivo em 20 segundos);

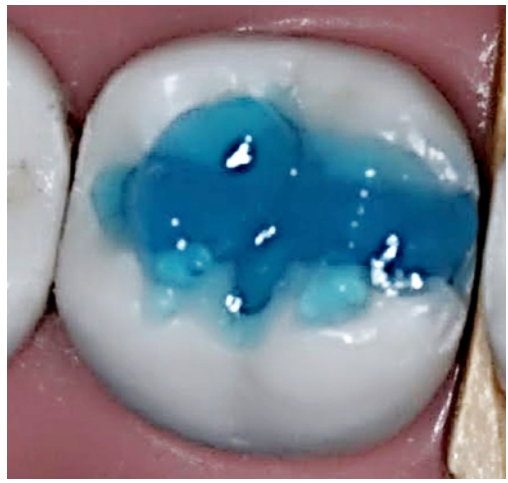

Figura 3: Técnica adesiva convencional de dois passos Fonte: autores, 2021

- Adaptação da matriz

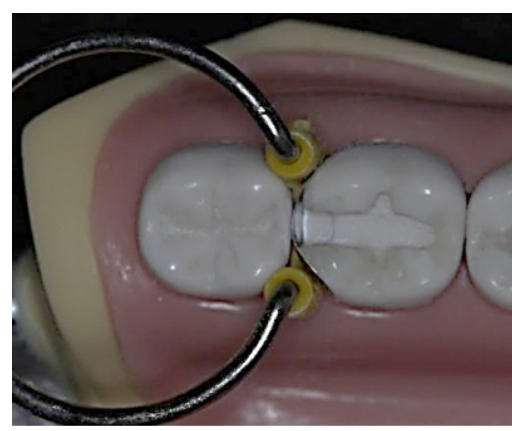

Figura 4: Adaptação da matriz Fonte: autores, 2021 
- Construção da parede proximal com resina de esmalte

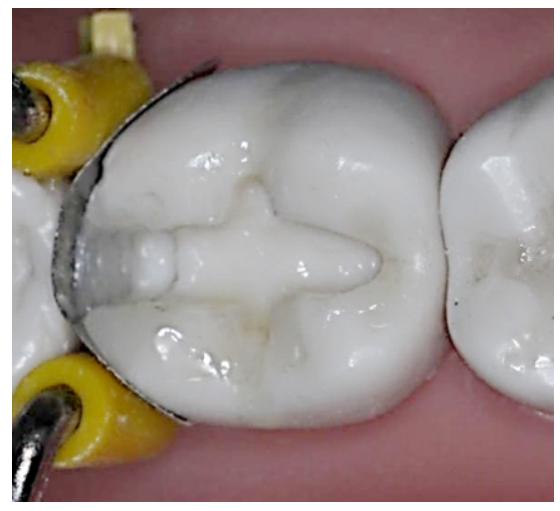

Figura 5: Construção da parede proximal com resina Fonte: autores, 2021

- Aplicação de resina flow na caixa próxima, pequena quantidade

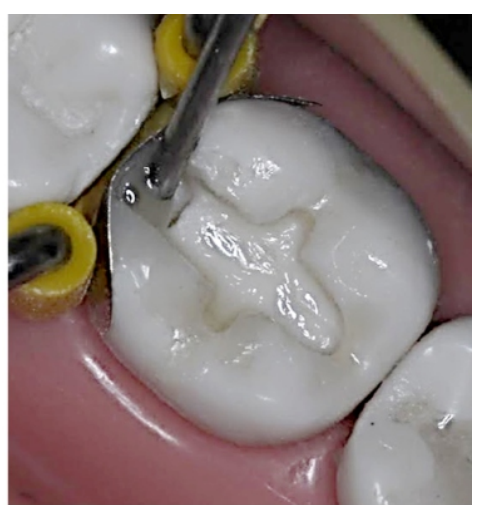

Figura 6: Aplicação de resina flow Fonte: autores, 2021

- Antes de polimerizar a resina flow, aplica-se a resina de dentina sobre ela;
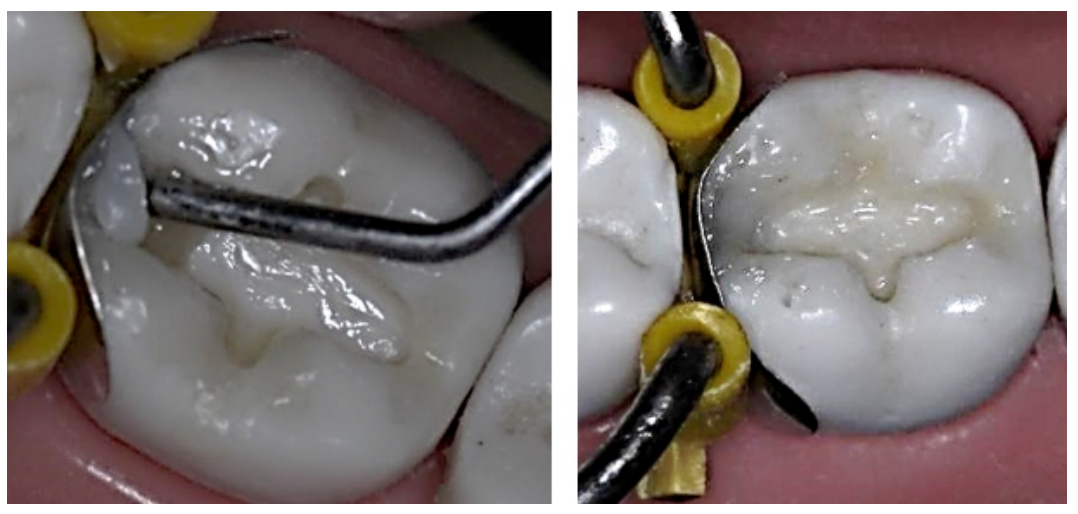

Figura 7: Aplicação da resina de dentina Fonte: autores, 2021

- Aplicação de resina de dentina construindo as cúspides, deixando aproximadamente a distância de $0,5 \mathrm{~mm}$ sem se tocarem, e com espaço na margem oclusal para colocação de esmalte; 


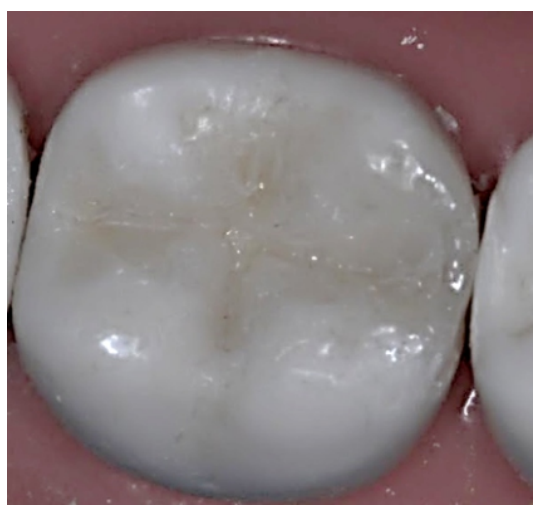

Figura 8: Aplicação de resina de dentina Fonte: autores, 2021

- Após isso fotoativa-se;

- Em seguida, constrói-se a camada de esmalte;

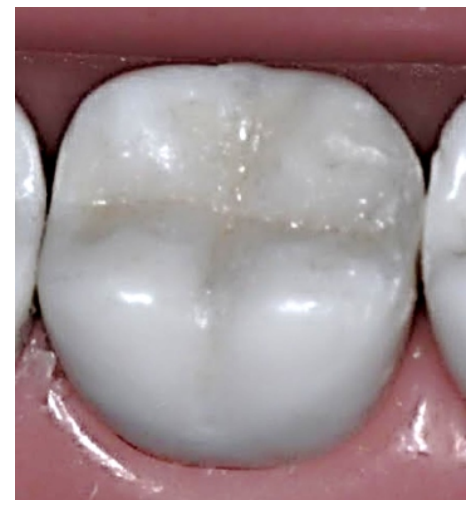

Figura 9: Construção da camada de esmalte Fonte: autores, 2021

- Ajuste oclusal com brocas multilaminadas para acabamento em resina em alta rotação;

- Acabamento (pontas diamantadas de granulação fina e ultrafina ou as brocas multilaminadas em alta rotação; discos flexíveis de óxido de alumínio (Sof-Lex ou TDV) em ordem decrescente de abrasividade ou utilizar as pontas siliconadas abrasivas - Kit TDV);

- Polimento (disco de feltro com pasta diamantada de polimento). 


\section{Técnica de restauração por Gustavo Barrote}

- Técnica adesiva de sua escolha;

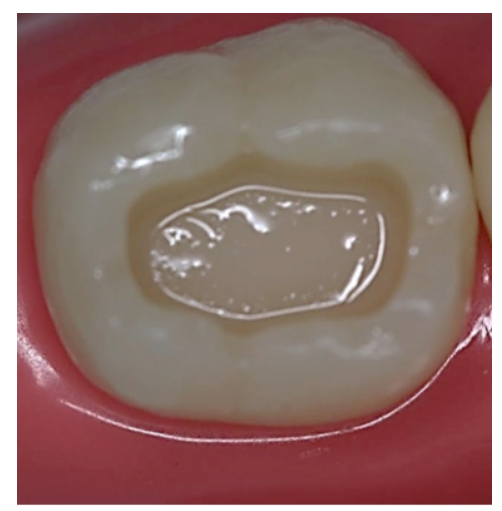

Figura 10: Técnica adesiva Fonte: autores, 2021

- Base de 0,5 mm de resina flow e fotoativação;
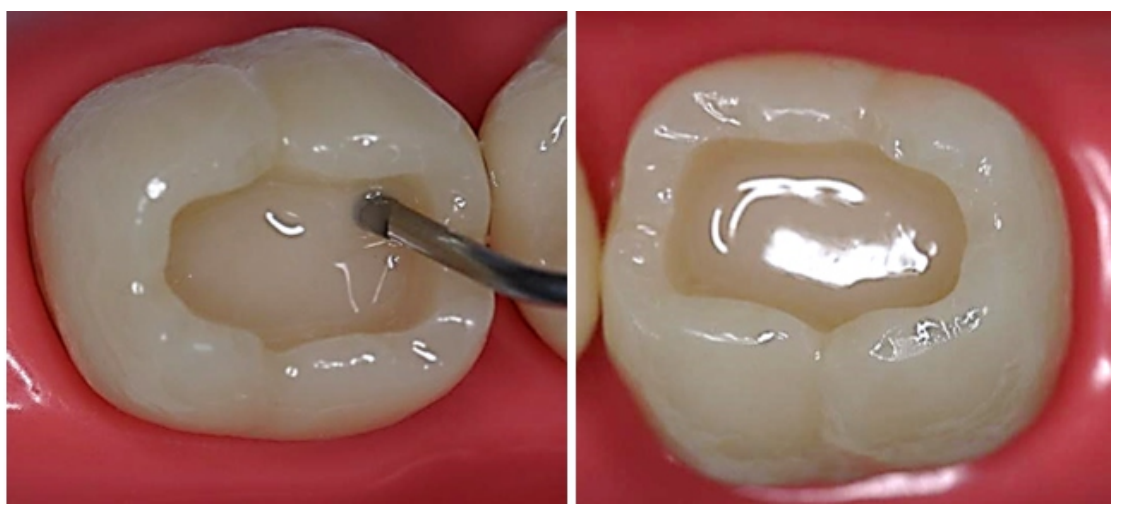

Figura 11: Resina flow e fotoativação Fonte: autores, 2021

- Inserção de dois incrementos de resina para dentina
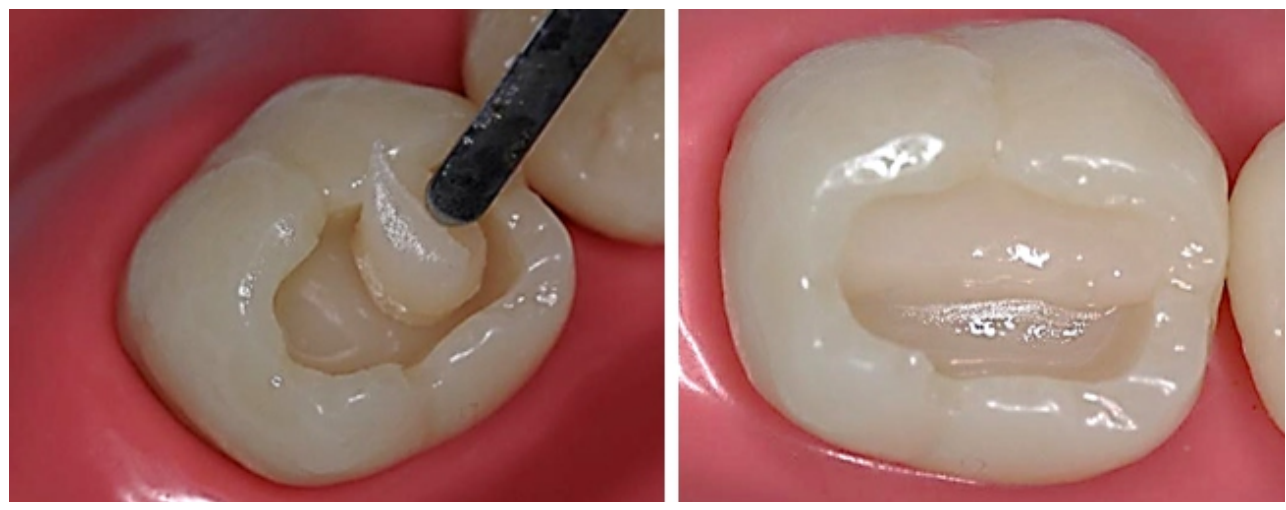

Figura 12: Inserção de dois incrementos de resina Fonte: autores, 2021 
- Com a espátula de medição, deixar aproximadamente $2,0 \mathrm{~mm}$ restantes a fim de que se coloque o esmalte;

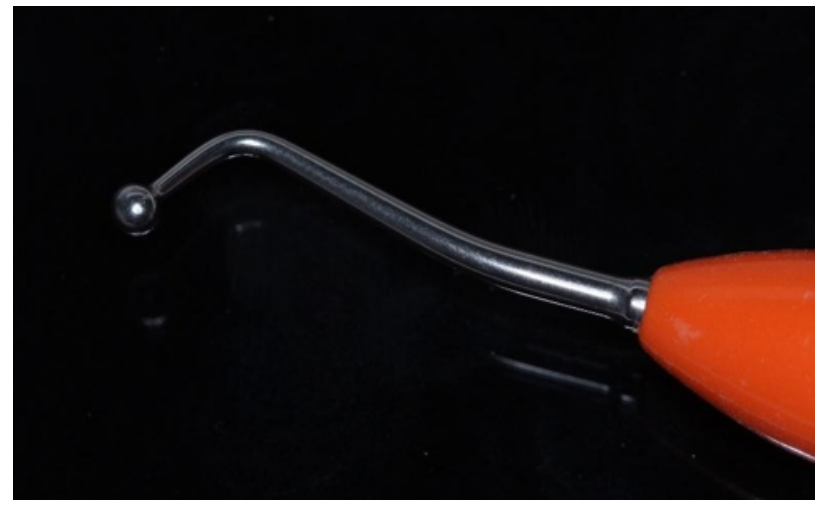

Figura 13: Espátula de medição

Fonte: autores, 2021

- Inserir resina de esmalte até a margem da restauração

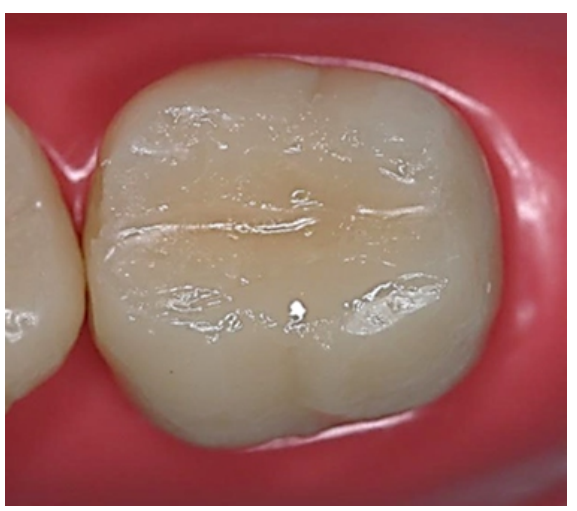

Figura 14: Inserir resina de esmalte Fonte: autores, 2021

- Desenhar os sulcos e esculpir as cúspides;

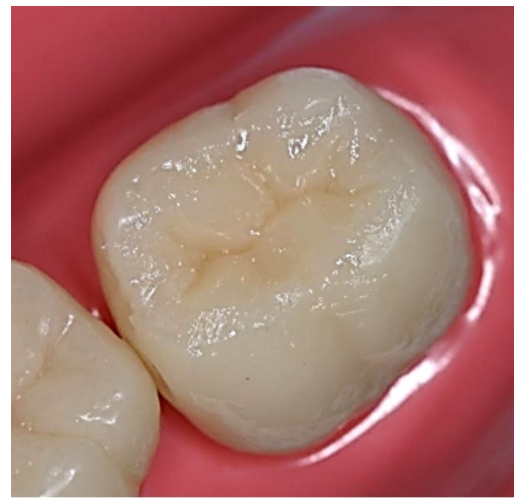

Figura 15: Desenhar os sulcos Fonte: autores, 2021 
- Aplicação de corante ocre e marrom nos sulcos;
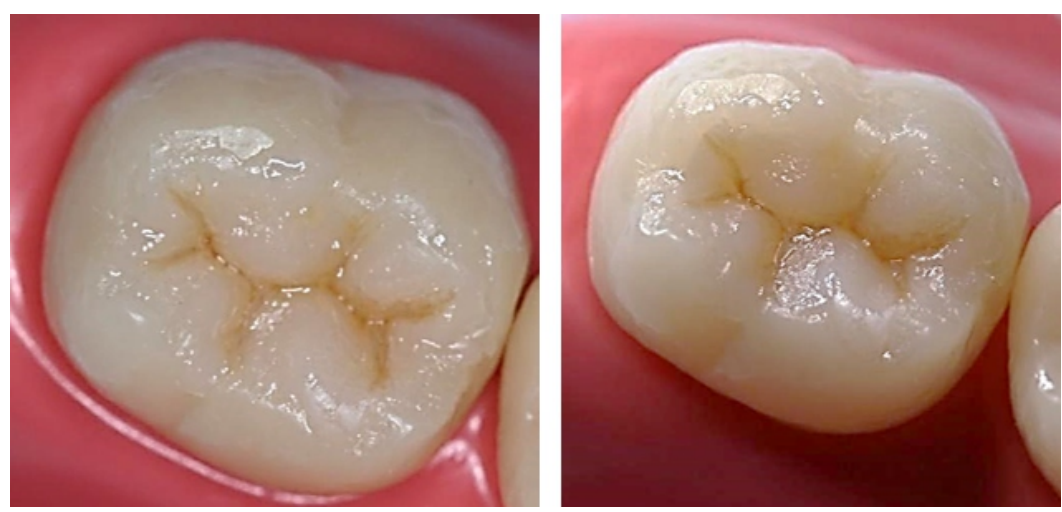

Figura 16: Aplicação de corante

Fonte: autores, 2021 


\section{REFERÊNCIAS}

1. FERRACANE, Jack L. Resina composta - estado da arte. Materiais dentários, v. 27, n. 1, p. 29-38, 2011.

2. OPDAM, N. J. M. et al. Longevity of posterior composite restorations: a systematic review and meta-analysis. Journal of dental research, v. 93, n. 10, p. 943-949, 2014.

3. HIRATA, Ronaldo, Shortcuts In Esthetic Dentistry. 1st ed. São Paulo: Quintessence Editora, 2016. 


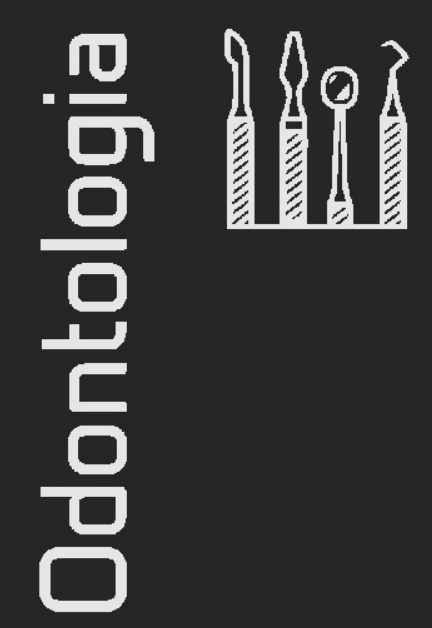

\section{PROTOCOLOS CLÍNICOS EM DENTÍSTICA RESTAURADORA: UMA VISÃO SIMPLIFICADA}

\section{Autores:}

Talita Arrais Daniel Mendes Karlos Eduardo Rodrigues Lima Eduardo da Cunha Queiroz

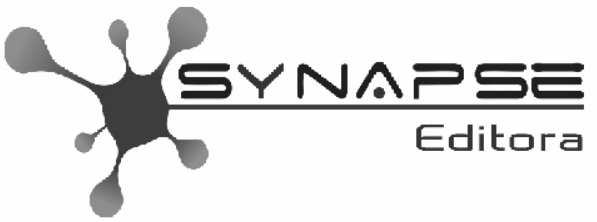

Compartilhando conhecimento 


\section{Sobre os Autores}

\section{Talita Arrais Daniel Mendes}

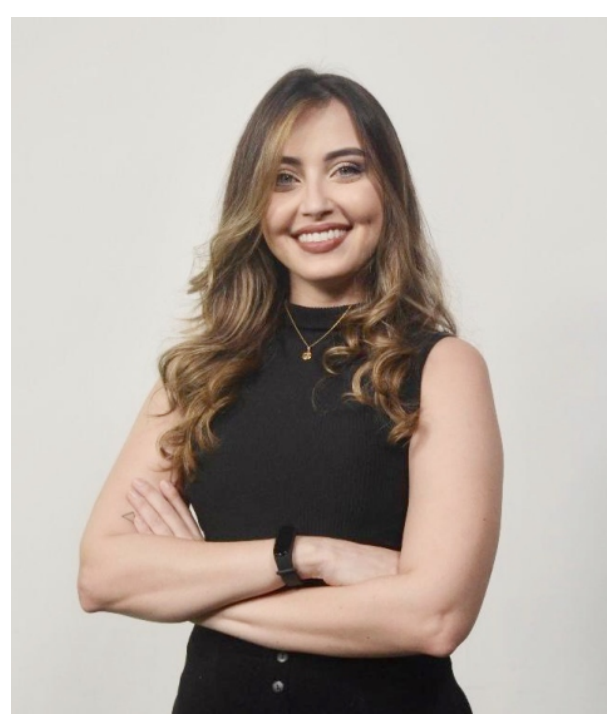

Graduada em odontologia pela Universidade Federal do Ceará (UFC)

Especialista em prótese dentária pela associação cearense de odontologia (ACO-CE)

Aperfeiçoamento em cirurgia periodontal pelo instituto estudo e serviço odontológico (IESO)

Aperfeiçoamento em estética orofacial associação brasileira de odontologia (ABO-CE)

Especialização em periodontia associação brasileira de odontologia (ABO-CE)

Mestra em odontologia com ênfase em dentística Universidade Federal do Ceará (UFC)

Doutoranda em odontologia com ênfase em dentística Universidade Federal do Ceará (UFC)

\section{Karlos Eduardo Rodrigues Lima}

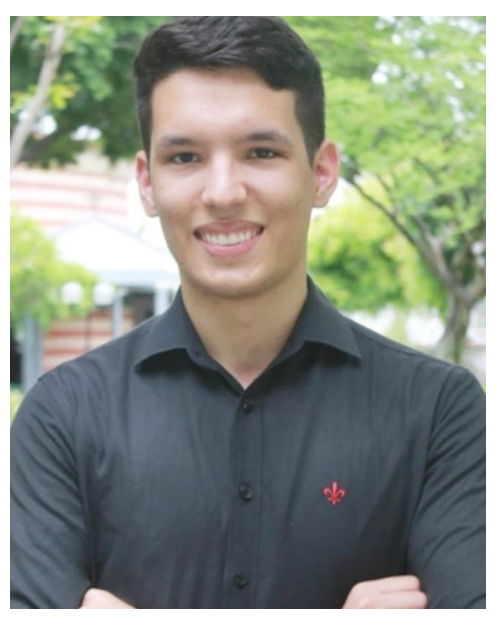

Graduação em Odontologia pelo Centro Universitário Católica de Quixadá (UNICATÓLICA)

Monitoria da disciplina de Pré-clínica I (UNICATÓLICA) 


\section{Sobre os Autores}

\section{Eduardo da Cunha Queiroz}

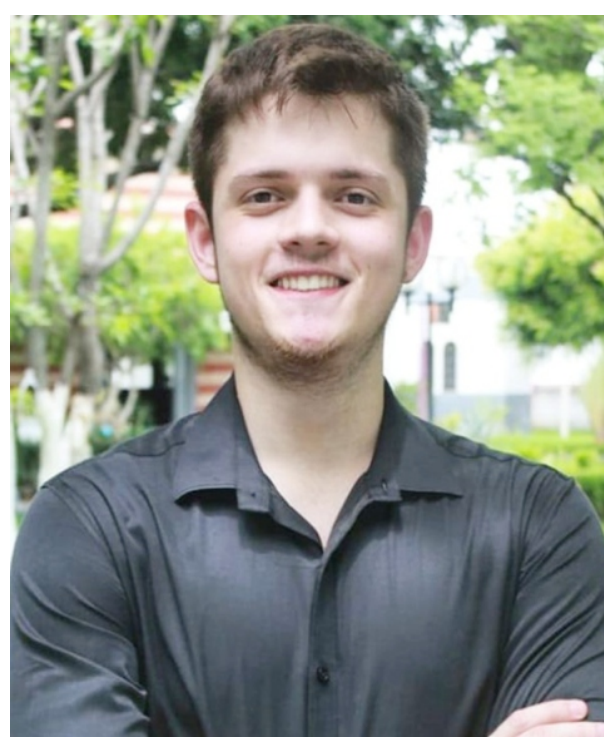

Graduação em Odontologia pelo centro universitário católica de Quixadá (UNICATÓLICA)

Monitoria da disciplina de clínica odontológica I (UNICATÓLICA) 


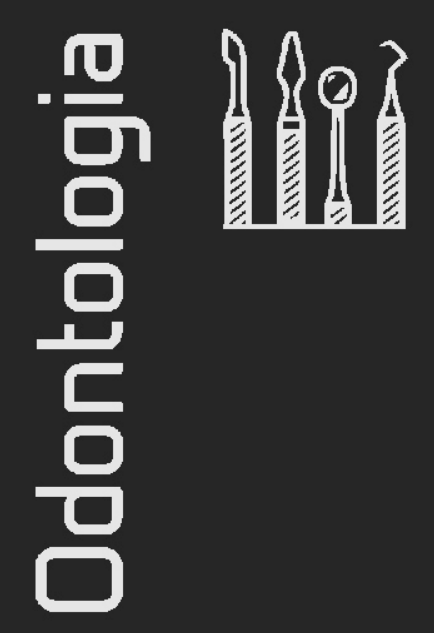

https://www.facebook.com/Synapse-Editora-111777697257115

(0) https://www.instagram.com/synapseeditora

in https://www.linkedin.com/in/synapse-editora-compartilhando-conhecimento/

$3198264-1586$

editorasynapse@gmail.com

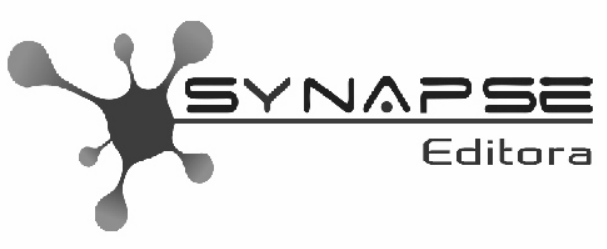

Compartilhando conhecimento 